Claudionor Almir Soares Damasceno

\title{
Políticas públicas e o direito à comunicação na América Latina. Os casos do Brasil e Venezuela
}

\author{
Universidade de São Paulo \\ Programa de pós-graduação em integração da América Latina \\ Prolam \\ São Paulo \\ 2012
}


Claudionor Almir Soares Damasceno

\section{Políticas públicas e o direito à comunicação na América Latina. Os casos do Brasil e Venezuela}

Dissertação apresentada ao Programa de Pós- Graduação em Integração da América Latina da Universidade de São Paulo - PROLAM/USP como requisito final para obtenção do título de Mestre.

Área de Concentração: Integração da América Latina.

Orientador: Prof. Dr. Sedi Hirano 
Nome: DAMASCENO, Claudionor Almir Soares.

Título: Políticas públicas e o direito à comunicação na América Latina.

Os casos do Brasil e Venezuela

Dissertação apresentada ao Programa de PósGraduação em Integração da América Latina da Universidade de São Paulo - PROLAM/USP como requisito final para obtenção do título de Mestre.

Aprovado em: de de 2012

Banca Examinadora

Prof. Dr. Sedi Hirano - Instituição: USP

Julgamento: Assinatura:

Prof. Dr, Carlos Eduardo Martins - Instituição: UFRJ

Julgamento: Assinatura:

Prof. Dr. Pietro Lora Alarcón - Instituição: PUC-SP

Julgamento: Assinatura: 
Dedico esse trabalho à memória dos meus pais Maria da Conceição Soares Damasceno e João Batista Damasceno.

Aos que sonham, aos que lutam. 


\section{AGRADECIMENTOS}

Agradeço a todos que participaram dessa obra, direta ou indiretamente. Primeiramente, ao meu orientador, Dr. Sedi Hirano, fonte de inspiração e sabedoria.

Agradeço também aos meus irmãos e familiares, que, longe ou perto, estiveram sempre presentes, apoiando com estímulos, força e carinho.

Agradeço aos amigos Leonardo, Mônica, Adauto, André, Hélcie, Marlene, Tatiana, Patrícia, Ana Paula, Aleksandra, Frank e Cláudia, sempre entusiastas e fiadores de esperanças. 
Virá o tempo em que a Declaração Universal dos Direitos Humanos terá de abarcar um direito mais amplo que o direito humano à informação, estabelecido pela primeira vez 21 anos atrás no Artigo 19. Trata-se do direito do homem de se comunicar. 


\section{RESUMO}

Esta pesquisa estuda as políticas públicas de comunicação na América Latina buscando identificar o papel que desempenham e qual a sua contribuição para que se garanta o exercício efetivo do direito à comunicação na América Latina. Seu foco esta na análise de documentos da UNESCO e das formulações relativas ao direito à comunicação sistematizadas na década de 70 e das novas e recentes políticas de comunicação que surgiram na América Latina, buscamos entender a forma como contribuem para a garantia do direito à comunicar. Partindo da constatação de que as mudanças e transformações políticas que o continente vive desde o início do século trouxeram para o centro do debate a questão da democratização dos meios de comunicação e da urgência de políticas públicas para o setor, questionamos até que ponto se conseguiu dar resposta à bandeira do direito à comunicação levantada pelos movimentos sociais. Elaboramos um panorama geral dos sistemas públicos do Brasil e Venezuela, utilizamos a coleta de dados, a observação, a entrevista e pesquisa bibliográfica para ancorar nossa análise, que desenvolvemos utilizando o conceito de hegemonia, amplamente desenvolvido por Antonio Gramsci. Constatamos as dificuldades que as políticas públicas ainda encontram para disputar a hegemonia na produção do imaginário social, o que pode ser atribuído tanto ao seu caráter inovador quanto à sua insuficiência.

Palavras-chave: políticas públicas, comunicação, direito à comunicação, hegemonia. 


\section{RESUMEN}

Esta investigación estudia las políticas de comunicación en América Latina, buscando identificar su papel y su contribución para que se garantize el ejercicio efectivo del derecho a la comunicación en nuestro continente. Su foco se centra en el análisis de los documentos de la UNESCO y de las formulaciones para el derecho a la comunicación sistematizada en los años 70, buscando entender cómo las recientes políticas de comunicación en curso en América Latina alcanzan contribuir con garantizar el derecho a comunicar. En el supuesto de que los cambios políticos que el continente ha gozado desde el principio del siglo trajo al centro del debate la cuestión de la democratización de los medios de comunicación y la urgencia de políticas públicas para el sector, nos preguntamos hasta qué punto logró respuesta a la bandera de los derechos a la comunicación planteadas por los movimientos sociales. Elaboramos una visión general de los sistemas públicos de Brasil e Venezuela, utilizamos la recolección de datos, la observación, la entrevista y la literatura para anclar nuestro análisis, buscando apoyarse en el concepto de hegemonía, en gran medida desarrollado por Antonio Gramsci. Constatamos las dificultades que las políticas públicas todavía están sufriendo para garantizar la hegemonía en la producción de imaginario social, las cuales se pueden atribuirse tanto a su carácter innovador en cuanto a su insuficiencia.

Palabras clave: política pública, la comunicación, derecho a la comunicación, la hegemonía. 


\begin{abstract}
This research studies the communication policies in Latin America seeking to identify their role and contribution in order to guarantee the effective exercise of the right to communicate in Latin America. His focus is on analysis of documents of UNESCO and the formulations for the right to communication that was systematized in the 70's decade, also the new and recent communication policies that have emerged in Latin America. We try to understand how they really contribute to guarantee the right to communicate. On the assumption that changes and political changes that the continent has enjoyed since the beginning of the century brought to the center of the debate the question of democratization of the media and the urgency of public policies for the sector, we question the extent to which managed to response to the flag of the communication rights raised by social movements. We draw an overview of the public systems of both countries, Brazil and Venezuela; we use data collection, observation, interview and literature to anchor our analysis, that we have developed using the concept of hegemony, largely developed by Antonio Gramsci. We note the difficulties that public policies are still to struggle for hegemony in the production of social imagination, which can be attributed both to its innovative character as to its insufficiency.
\end{abstract}

Keywords: public policy, communication, right to communication, hegemony. 


\section{LISTA DE SIGLAS E ABREVIATURAS}

ABC: American Brodcasting Corporation

ABEPEC: Associação Brasileira de Ensino e Pesquisa em Comunicação

ABI: Associação Brasileira de Imprensa

ABRAÇO: Associação Brasileira de Radiodifusão Comunitária

ACPO: Acción Cultural Popular

AMARC: Associação Mundial de Rádios Comunitárias

ARLESP: Associação de Rádios Livres do Estado de São Paulo

CBS: Columbia Broadcasting Service

CEB: Comunidade Eclesial de Base

CEC: Centro de Estudos em Comunicação e Cultura

CIA: Central Inteligence Agency

CMI: Centro de Mídia Independente

CNBB: Confederação Nacional dos Bispos do Brasil

CPI: Comissão Parlamentar de Inquerito

EBC: Empresa Brasileira de Comunicação

ENECOM: Encontro Nacional dos Estudantes de Comunicação Social

ENECOS: Executiva Nacional dos Estudantes de Comunicação Social

FENAJ: Federação Nacional dos Jornalistas

FNDC: Fórum Nacional pela Democratização das Comunicações

FNPDC: Frente Nacional de Luta por Políticas Democráticas de Comunicação

IPEA: Instituto de Pesquisas Aplicadas

MNA: Movimento dos Paises Não-Alinhados

MNDC: Movimento Nacional pela Democratização da Comunicação

NOMIC: Nova Ordem Mundial da Informação e da Comunicação

OAB: Ordem dos Advogados do Brasil

OMC: Organização Mundial do Comércio

ONU: Organização das Nações Unidas

PBS: Public Brodcastin Service

PNC: Políticas Nacionais de Comunicação

RCA: radio Corporation of America

RCTV: Radio Caracas de Televisão 
SAL-OCIC: Secretariado para América Latina da Organização Católica Internacional de Comunicação

TVE: Televisão Educativa

UCBC: União Cristã Brasileira de Comunicação

UCIP: União Católica Internacional de Imprensa

UCLAP: União Católica Latino-Americana de Imprensa

UNDA-AL: Associação Católica Latino-Americana para Rádio e Televisão

UNESCO: Organização das Nações Unidas para Educação, Ciência e Cultura

URSS: união das Repúblicas Socialistas Soviéticas 


\section{SUMÁRIO}

INTRODUÇÃ

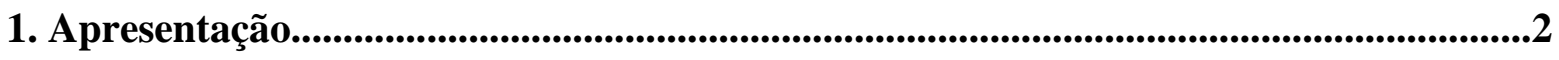

2. Estágio do desenvolvimento do tema..............................................................................................3

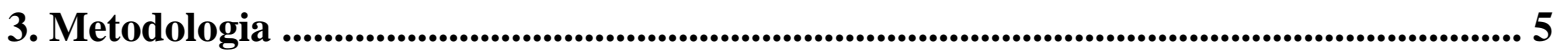

4 Estrutura do texto................................................................................................................8

CAPÍTULO I: Conceitos teóricos utilizados..............................................................................10

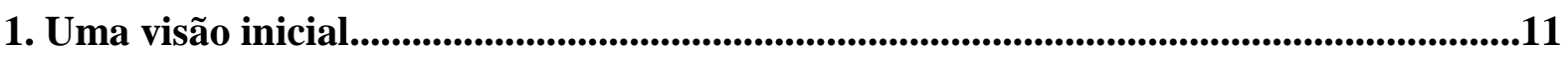

2. Hegemonia...................................................................................................................12

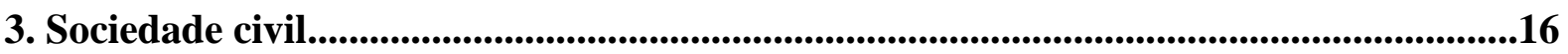

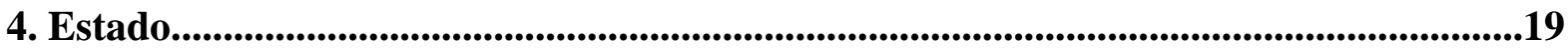

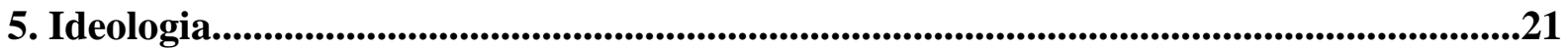

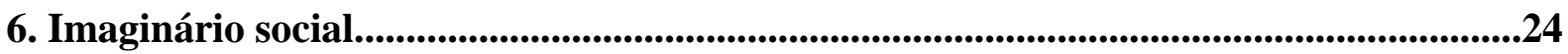

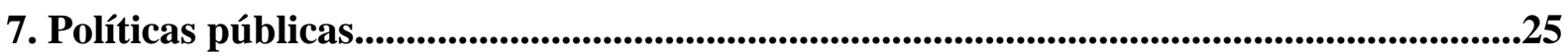

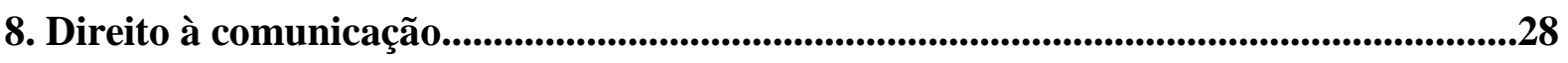

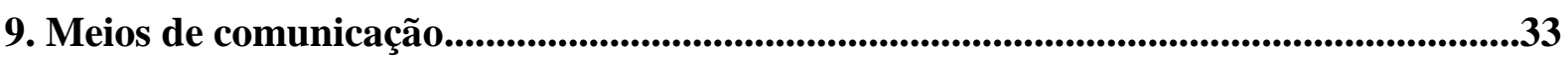

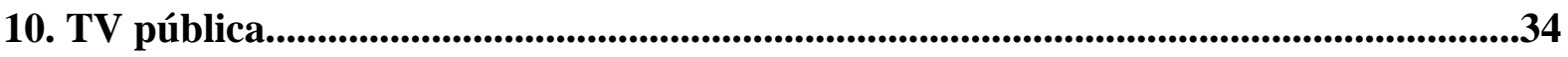

CAPÍTULO II: Contextualização.................................................................................42

1. Preâmbulo: a formação dos monopólios................................................................43

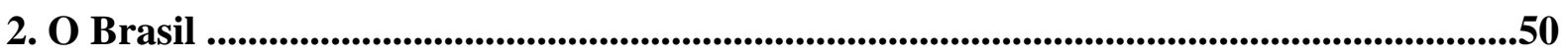

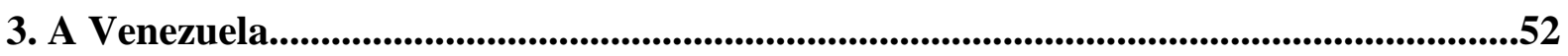

4. A UNESCO e o debate sobre a democratização e a circulação de informação..............54

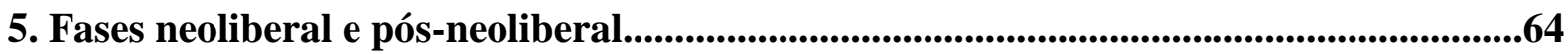

CAPÍTULO III: Governos progressistas, políticas públicas e o direito à comunicação 70 1. O retorno das políticas públicas de comunicação na América Latina do século XXI..71

2. Disputas hegemônicas na América Latina do século XXI............................................76

3. Políticas públicas e a regulamentações em debate.............................................................84

CONSIDERAÇÕES FINAIS...........................................................................................98

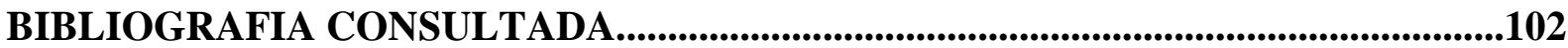




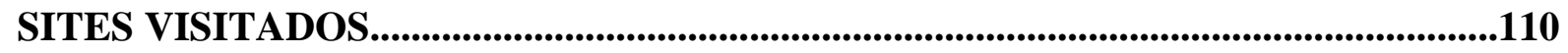

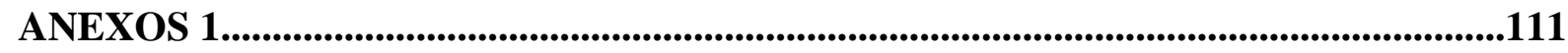

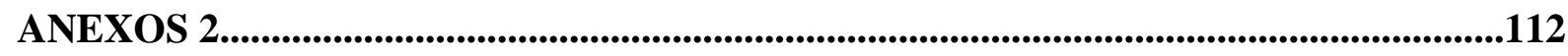

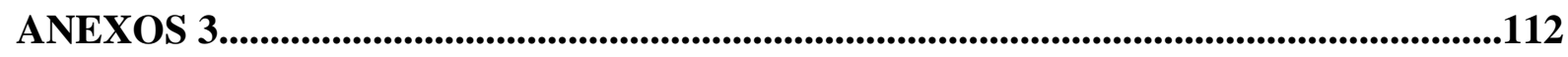

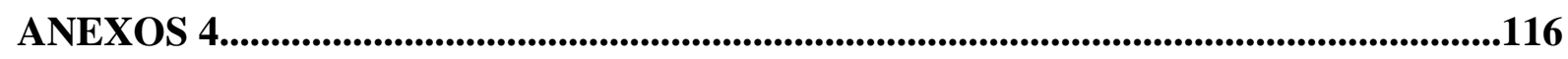




INTRODUÇÃO 


\section{1- Apresentação}

Este trabalho pretende contribuir com as pesquisas que analisam o papel exercido pelas políticas públicas de comunicação na América Latina no sentido de garantir o direito à comunicação. Busca compreender o lugar que estas políticas públicas ocupam e o seu desempenho no processo de formação de nosso imaginário social tentando entender os seus significados e sua importância, assim como as dificuldades e empecilhos que enfrentam para a sua concretização enquanto políticas de Estado e espaço da sociedade civil.

Muito embora o nosso recorte histórico se situe na contemporaneidade do século XXI e nas atuais políticas públicas surgidas no âmbito de governos recentemente eleitos, que majoritariamente se alinham com um discurso anti-neoliberal, sentimos a necessidade de realizar uma incursão no passado das últimas décadas, com o propósito de entender e situar melhor o presente debate. Para isso buscamos contextualizar o processo de formação dos monopólios de comunicação na América Latina nos idos dos anos 60, suas características marcadamente privadas e de forte influência estrangeira, em muito decorrente da conjuntura do pós-Segunda Guerra. Tentamos identificar o surgimento do debate sobre o direito à comunicação no âmbito do movimento dos países não-alinhados, visualizando os conflitos de interesses que permeiam esse assunto, localizando sua erupção na esfera dos debates ocorridos na UNESCO nos anos 80. Também identificamos este organismo internacional como o palco dos debates onde se condensaram as primeiras propostas de políticas públicas de comunicação, surgidas em contraposição ao livre fluxo de informação e à hegemonia do mercado neste setor.

Delimitamos as situações específicas do Brasil e da Venezuela como espaço de nossa análise, o que procuramos fazer estudando as recentes iniciativas de políticas públicas de comunicação ocorridas nesses dois países, comparando suas distintas características e tentando entender seus propósitos e resultados. Marcadamente, na Venezuela o surgimento da Ley Resort, o lançamento do satélite Simon Bolívar e a criação de novos canais públicos de televisão, assim como um sensível incentivo aos meios de comunicação comunitários, estimularam o nosso interesse por aquele país. No Brasil nos interessaram os debates no âmbito da ANCINAV, que culminaram com a criação da EBC, assim como as discussões que vêm ocorrendo sobre a necessidade de uma regulamentação dos meios de comunicação.

Em diversos outros países da América Latina, como a Argentina, a Bolívia e o Equador, este debate sobre políticas públicas de comunicação também surgiu e vem 
ocorrendo de diversas formas, tendo geralmente como fruto a criação de canais públicos e também de novas leis e marcos regulatórios para a comunicação.

A partir da evidência de que este debate vem ganhando força e dimensão, achamos importante que investigações acadêmicas reflitam sobre ele. Por essa razão nossa pesquisa procurou levantar problematizações que pudessem contribuir de alguma forma com esta discussão. Achamos importante colocar questões concretas que, a partir de uma visão crítica, nos auxiliassem a dimensionar o peso real e efetivo dessas políticas para o fortalecimento do processo de mudanças em curso no continente.

Partindo dessas premissas, o esforço que realizamos aqui foi o de questionar e procurar entender se, de fato, as atuais políticas públicas de comunicação em curso nesses dois países contribuem para o exercício do direito à comunicação e até que ponto podemos entendê-las como contribuição. Como disputam a hegemonia na formação do nosso imaginário social? Nosso objeto de estudo serão as recentes políticas públicas no Brasil e na Venezuela, particularmente no que refere ao fortalecimento das redes públicas de comunicação e na criação de marcos regulatórios.

\section{2- Estágio do desenvolvimento do tema}

Foi nos fóruns da UNESCO, a Organização das Nações Unidas para a Educação, a Ciência e a Cultura, que o debate internacional sobre a democratização da comunicação surgiu desde a década de 60 , em meio às disputas e pressões dos países chamados de não alinhados, que defendiam a construção de um equilíbrio no fluxo de informações entre os países. A partir do questionamento sobre o conteúdo e a concentração da propriedade dos meios, uma UNESCO que contava com uma forte presença de países socialistas e dos chamados países não-alinhados defendia a implementação de políticas nacionais com o objetivo de garantir o acesso e o direito do povo à comunicação, debate que surgiu a partir do questionamento do livre fluxo de informação, que se traduzia na prática como uma via de mão única, dos países desenvolvidos para os em vias de desenvolvimento. A polêmica gerada por esse posicionamento, o que incluía a reação dos monopólios, que os classificava como cerceio à liberdade de imprensa, fez com que em 1976 a Conferência Geral da UNESCO criasse a Comissão Internacional para o Estudo dos Problemas da Comunicação, presidida pelo irlandês Sean MacBride e amplamente representativa dos países membros (UNESCO, 1983). 
Como resultado dos trabalhos desta comissão, o Relatório MacBride, intitulado "Um Mundo e Muitas Vozes - Comunicação e Informação na nossa Época”, de 1980, tornou-se um marco divisor neste debate ao defender que o processo de democratização da comunicação compreenderia medidas como a implementação de políticas de aumento do acesso aos meios, incentivo à comunicação alternativa e uma mudança de perspectiva em relação à comunicação, condensando tudo na ideia de uma Nova Ordem Mundial da Informação e da Comunicação (NOMIC). Esse posicionamento contribuía para estabelecer pela primeira vez um entendimento da comunicação como um direito humano fundamental, resgatando aquilo que Jean D’Arcy já defendia em 1969, ultrapassando o direito à informação, ampliando-o ao sentido de que todas as pessoas devem ter o direito de informar, ser informado, trocar ideias e opiniões, por quaisquer meios de comunicação, sem qualquer restrição. Quando diretor do Departamento de Informações das Nações Unidas, D’Arcy escreveu que

Virá um tempo em que a Declaração Universal dos Direitos Humanos terá de englobar um direito mais amplo do que o direito do homem à comunicação, colocado há 21 anos no Artigo 19. Trata-se do direito do homem de comunicar-se. Este é o ângulo a partir do qual o desenvolvimento futuro das comunicações terá de ser considerado, se se desejar seu total entendimento (UNESCO, 1983).

Essa perspectiva mais ampla, que preconiza uma relação dialética na comunicação, vai ao encontro daquilo que o educador Paulo Freire, em seu ensaio "Extensão ou comunicação?" , percebia como condição para que se garanta uma relação entre iguais na sociedade. Recorrendo à raiz semântica da palavra comunicação, Freire exclui dela toda relação de poder, pois necessariamente o ato de comunicar só ocorre entre sujeitos iguais, mediados pelo objeto de conhecimento decorrente do trabalho e da experiência. $\mathrm{Na}$ perspectiva de Freire a comunicação é, por definição, dialógica, o que contempla o direito de ser informado e o direito de acesso aos meios necessários à plena liberdade de expressão (LIMA, 2011).

As propostas da NOMIC, rejeitadas durante os anos 90, em que a influência do pensamento neoliberal cresceu e se tornou hegemônico na América Latina, sobrevivem através de entidades da sociedade civil e reaparece na UNESCO quando da realização, em

\footnotetext{
${ }^{1}$ FREIRE, Paulo. Extensão ou comunicação?. Rio de Janeiro, Editora Paz e Terra, 1983. Nesta importante obra, o educador discute sobre o equívoco da nomeação do trabalho dos agrônomos como atividade de "extensão", propondo que estes, assim como o professor em geral, se quiserem chegar ao homem concreto inserido numa realidade histórica, não ao ser abstrato, devem pautar suas ações educadoras na comunicação.
} 
2005, da Convenção sobre Proteção e a Promoção da Diversidade das Expressões Culturais². Em seu documento final, este encontro reafirma a necessidade de políticas públicas de proteção e estímulo às políticas culturais como forma de fazer frente à globalização, que a fragiliza devido ao seu aspecto de "dupla" natureza.

Nosso objetivo neste trabalho é avaliar se as políticas públicas colocadas em discussão e em prática na América Latina nesse processo recente, em algum nível conseguem dar resposta à reivindicação do exercício do direito à comunicação. Queremos analisar até que ponto essas políticas públicas refletem anseios da população e de seus movimentos sociais e como contribuem para que o direito à comunicação se concretize.

Sendo assim, nosso interesse por esse tema partiu da constatação de que a emergência do debate sobre políticas públicas de comunicação se localiza no âmbito dessas transformações, percepções e choques de interesses, que apontam para a necessidade de que a produção de informação, comunicação e entretenimento seja democratizada em todo o continente, acompanhando o processo de mudança geral em curso. Muito embora nesse contexto de mudanças tenham surgido propostas de aumentar a interferência legal e os mecanismos de fiscalização pública e a taxação dos lucros das empresas midiáticas, além da criação de associações regionais para coordenar a criação cultural endógena e a circulação de informações, entre outras propostas defendidas por intelectuais como Néstor García Canclini (2008), este quadro ainda não se refletiu em estudos que analisem seus efeitos. Nosso trabalho se justifica a partir dessa necessidade, centrando seu foco nas políticas públicas e em suas consequências para a democratização da comunicação.

\section{3- Metodologia}

Do ponto de vista metodológico, nosso trabalho se enquadra na definição de pesquisa exploratória, pois na sua realização utilizamos o levantamento bibliográfico e documental, entrevistas não padronizadas, análise qualitativa e estudo de casos com vistas a desenvolvimentos em estudos posteriores. Nossa preocupação foi a de buscar procedimentos intelectuais e técnicos que nos possibilitassem sair do senso comum, mas entendendo que não existe uma forma universal possível de ser aplicada a todas as pesquisas. Sabemos que existem diversos tipos de métodos que, de acordo com o objeto de estudo a que se propõe investigar, pode ser mais útil, sendo estes os caminhos para se chegar a determinado fim, no

\footnotetext{
${ }^{2}$ Disponível em: http://unesdoc.unesco.org/images/0015/001502/150224por.pdf (consultado em 01.12.11).
} 
dizer de Antonio Carlos Gil (1995). Ao se estruturar a partir de necessidade de encontrar uma resposta a um questionamento sobre aquilo que ainda não se conhece, a pesquisa científica é uma coisa viva, que necessita do uso de determinados procedimentos para que seus resultados possam ser considerados verdadeiros (Lucia Santaella, 2001).

Nosso trabalho foi sendo lapidado em diversas etapas, tendo se iniciado com a pesquisa bibliográfica, o que incluiu a identificação do tema e assunto, seleção de fontes (bibliografias, portais, resumos de teses e dissertações e catálogos de editoras. Após a localização e obtenção do material, realizamos o processo de leitura, revisão da literatura e fichamento. Utilizamos a coleta de dados, a observação, entrevistas não padronizadas. Nesse sentido, realizamos trabalhos de campo, visitando as emissoras TV Cultura e TV Brasil aqui em São Paulo, participando de diversos debates, seminários e eventos que problematizaram o tema de políticas públicas, meios de comunicação, regulamentação e democratização da mídia. Realizamos também o trabalho de campo durante o mês de julho de 2010 na Venezuela, oportunidade em que pudemos coletar informações, conhecer as estruturas das emissoras e realizar entrevistas com seus dirigentes e se apropriar um pouco mais da realidade daquele país. Após o trabalho de coleta de dados e informações, entramos na etapa de análise e, por fim, de redação do texto.

Quanto aos conceitos, procuramos usar referências teóricas que nos possibilitassem ultrapassar o empirismo, se apoiando na compreensão de que, mais importante do que se vê e se observa é ver com método, para que o resultado não seja apenas a confirmação de concepções pessoais. Marx, ao criticar a ilusão de transparência do real, lembrava que "toda ciência seria supérflua se a essência das coisas e sua aparência fenomênica coincidissem diretamente" ${ }^{3}$, ou seja, só temos ciência quando conseguimos superar o dado imediato. Daí a importância de adotar uma teoria ou um modelo teórico que possibilitasse estabelecer princípios generalizantes. No entanto, a abstração não pode ser considerada como ponto de chegada, mas a categoria científica, o ponto de onde partimos com o objetivo de conhecer a realidade, o concreto. E um fenômeno definido pela lei científica se comprova enquanto tal no seu caráter de reiterabilidade. ${ }^{4}$

O conceito de hegemonia, amplamente desenvolvido por Antonio Gramsci, o qual fazemos uso neste trabalho, nos pareceu de grande utilidade para discutir o tema do direito à

\footnotetext{
${ }^{3}$ MARX, Karl. O capital. Rio de Janeiro: Civilização Brasileira, 1974, livro 3, v. 6, p. 939.

${ }^{4}$ De acordo com Marx, "o concreto é o concreto por ser a síntese de múltiplas determinações, logo, unidade da diversidade". A dialética entre procedimentos indutivos e dedutivos é discutida por ele no método da economia política (Marx, Karl. Contribuição à crítica da economia política. São Paulo: Martins Fontes, 1977).
} 
comunicação no âmbito das políticas públicas, pela sua riqueza enquanto pensamento crítico e dialético, auxiliando no entendimento do papel dos meios de comunicação como uma dinâmica fundamental nas disputas ideológicas que permeiam a sociedade. Gramsci dá uma importância relevante ao papel da sociedade civil como ambiente em que operam os aparelhos de hegemonia, entre os quais a mídia tem um papel fundamental. Recorremos aos Cadernos do cárcere, em sua edição organizada por Carlos Nelson Coutinho, como forma de se apropriar melhor dos conceitos gramscianos. Em seu segundo volume aparecem os textos em que Gramsci analisa o papel dos intelectuais e da educação a partir de um processo histórico e de sua transformações, enxergando neles uma função social para estes processos. É esse perspectiva ativa que ganha força neste livro, identificada no papel revolucionário atribuído por Gramsci aos intelectuais. No volume terceiro, fez-se fundamental a abordagem sobre o conceito de hegemonia e as reflexões sobre o Estado.

Recorremos também às obras de imensa relevância neste debate, como tem sido as do pensamento crítico da economia política da comunicação que, ao analisar a concentração midiática, os monopólios e a privatização dos fluxos de informação, esclarece aspectos fulcrais do problema da democratização da comunicação. Nesse caminho, um dos estudos relevantes sobre o tema é o do pesquisador Herbert Schiller que em sua vasta obra se detém na questão da democratização das comunicações em seu livro Culture, Inc., onde analisa os efeitos da crescente concentração e privatização da informação propiciadas pela mercantilização midiática e suas consequências para a democracia. No clássico $\mathrm{O}$ império norte-americano das comunicações, Schiller já havia feito um diagnóstico do processo de expansão da radiodifusão, vinculando seu desenvolvimento aos interesses da indústria eletroeletrônica e militar, articuladas com a hegemonia norte-americana do pós-guerra.

Outras valiosas contribuições para o pensamento crítico encontramos na obra de Dênis de Moraes, principalmente em seu livro A batalha da mídia, governos progressistas e políticas de comunicação na América Latina e outros assuntos. Neste trabalho o autor analisa os processos midiáticos do ponto de vista da luta necessária, e possível, a ser travada neste campo de disputas onde as forças populares jogam um papel decisivo. Destaca-se a imensa pesquisa e análise sobre as recentes políticas de comunicação dos governos progressistas na América Latina, descritas como permanente batalha e espaço de disputa pela hegemonia na produção do imaginário social no continente. 


\section{4- Estrutura do texto}

Nosso trabalho esta organizado em três estágios que se articulam e se complementam na discussão geral do tema. No primeiro deles, tentamos esclarecer os aspectos conceituais e teóricos que utilizamos durante o nosso trabalho. O segundo momento, são as questões históricas e a contextualização que tomarão corpo. Por último, buscamos focar mais propriamente o objeto de estudo, olhando a partir da perspectiva mais geral, mas focando nos aspectos das políticas públicas, como elas se articulam com a provável democratização da comunicação.

No primeiro capítulo encontraremos uma discussão teórica sobre os conceitos e definições utilizados em todo o trabalho, começando pelo conceito de hegemonia, mais propriamente através da contribuição que Gramsci deu ao seu entendimento valorizando os aspectos culturais e ideológicos em disputa na sociedade civil. Antes reduzido à coerção e à superioridade econômica, o conceito de hegemonia se amplia até a capacidade de uma classe social de dirigir moral e culturalmente o conjunto da sociedade. Discutiremos também sobre ideologia e imaginário social no âmbito do corpo de representações, símbolos e normas através das quais as pessoas explicam a si a vida coletiva. Da mesma forma tentaremos esclarecer os conceitos e concepções que aqui adotamos no que se refere às políticas públicas e TV pública, direito à comunicação, Estado e sociedade civil.

No segundo capítulo, buscamos contextualizar a história da formação dos monopólios dos meios de comunicação na América, juntamente com o mapeamento do processo de discussão e de construção da concepção da comunicação como um direito. Este foi organizado em três momentos, sendo o primeiro marcado pela hegemonia americana surgida no pós- Segunda Guerra e caracterizada pela doutrina do livre fluxo de informação. O segundo momento caracterizamos pelo debate e confronto aberto de concepções, singularmente ocorrido nos fóruns da UNESCO entre os anos 70 e 80, sendo o Relatório MacBride sua maior expressão. O terceiro momento de nossa contextualização tenta resgatar as diversas viradas anti-neoliberais ocorridas no continente, quando se incrementa o debate e surgem novas iniciativas de políticas públicas a partir desses governantes eleitos. 
No terceiro capítulo e último capítulo, tentamos fazer um levantamento dessas novas iniciativas de políticas públicas de comunicação que estes governos recém-eleitos adotaram, como parte integrante de suas bandeiras de mudança, integração e inclusão social. Neste sentido, listamos algumas das novas leis e marcos regulatórios surgidos nesse processo, além de emissoras e demais iniciativas que caracterizam uma reação estatal que se propõem a enfrentar a imensa concentração privada dos meios de comunicação. Particularmente listamos a Ley de médios da Argentina, a Ley Resort, na Venezuela, a criação das TVs Brasil, Telesur e TVes e de diversos meios de comunicação comunitários.

Nossa pretensão é unicamente a de buscar uma aproximação com o tema, consciente da complexidade e dimensão que o cerca, com a consciência de que essa tarefa significa se debruçar sobre assunto que demandaria aprofundamentos de ordens diversas, sejam elas culturais, históricas, filosóficas ou políticas, tarefa a qual não nos propomos. O que nos moveu unicamente foi a sensível necessidade que o tema desperta nos tempos atuais, cobrando da academia um esforço maior para que possa ser colocado em evidencia. 
CAPÍTULO 1: Conceitos teóricos utilizados 


\section{Uma visão inicial}

Uma das tarefas metodológicas mais importantes com a qual nos debruçamos para realizar esse trabalho foi a definição de um arcabouço teórico que nos auxiliasse da melhor forma a tratar as questões inerentes às disputas que envolvem uma discussão sobre políticas públicas e direito à comunicação. A diversidade teórica, assim como metodológica, expressa nos diferentes paradigmas científicos existentes ${ }^{5}$ nos remete ao fato de que o conhecimento é socialmente determinado, sendo condicionado pelo caráter histórico classista da sociedade capitalista em que estamos envolvidos. Esta condição já se expressa desde a escolha do objeto de estudo, dado que, no dizer de Otavio Ianni, “As representações que grupos e classes sociais constroem sobre a sociedade em que se encontram inseridos afetam, em grau variável, as possibilidades e as tendências do pensamento". 6 O discurso científico traduz a visão de mundo de determinada classe social, expressa através da produção de seus intelectuais orgânicos. Martin Barbero, ao discutir sobre o caráter dependente da Ciência na América Latina, critica a tendência a viver de modas e a estar atualizado, ao invés de se buscar ferramentas teóricas a partir dos processos sociais que vivemos. ${ }^{7}$

Partindo dessas considerações, podemos ainda constatar que um dos reflexos decorrentes das transformações históricas mundiais ${ }^{8}$ ocorridas nos anos 70 e 80 foi o surgimento do discurso de crise de paradigmas, a partir do qual se relegou ao segundo plano os modelos macroteóricos, abandonando-se os esquemas analíticos gerais e aderindo-se ao

\footnotetext{
${ }^{5}$ Lopes indica a existência de três modelos clássicos nas Ciências Sociais, sendo eles o funcionalismo, com base no pensamento de Durkheim; o weberianismo, baseado na obra de Max Weber; e o marxismo, na obra de Karl Marx. Esses paradigmas expressam o tipo de consciência possível no sistema social capitalista, o que, segundo a autora, citando Sartre, "são insuperáveis enquanto o movimento histórico de que são expressão não tiver sido superado". LOPES, 2005, p. 39.

${ }^{6}$ IANNI, Otávio. Sociologia da sociologia latino-americana, Rio de Janeiro, Civilização Brasileira, 1971, p. 9 (apud LOPES, 2005).

${ }^{7}$ BARBERO, Jesus-Martin. Desafios da pesquisa em comunicação na América Latina. Boletim INTERCOM, 49/50, São Paulo, 1984 (apud LOPES, 2005).

${ }^{8}$ A financeirização da economia mundial, decorrente da unilateral decretação do fim do padrão dólar-ouro e do fim dos acordos de Breton Woods de 1944, foi a medida adotada pelo presidente Nixon em 1971 para salvar a economia norte-americana de um enorme desequilíbrio externo devido ao crescente déficit orçamentário. Essa medida, longe de significar uma imposição natural dos mercados, se traduziu na tomada do centro do poder mundial pelo grande capital, na forma inédita do dólar flexível, abrindo as portas para a globalização financeira e para o que se chamou de época do neoliberalismo. Era a passagem do modelo keynesiano de bem-estar social para o neoliberal, a consolidação de um mundo unipolar e a hegemonia do "modo de vida americano" como valor e estilo de vida (cf. Belluzzo, 2004; Serrano, 2004).
} 
pós-modernismo. Assuntos que se vinculavam diretamente a estratégias de poder, como imperialismo, bloco hegemônico e o poder em si, foram quase esquecidos ou escanteados e substituídos pela discussão sobre temas como os micropoderes (Foucault, Deleuze e Guattari), os conceitos de poliarquia, de Dahl ou sociedades em rede, de Castells. (cf. Serrano, 2004; Sader, 2009). Uma das consequências dessa nova situação foi a difusão das ideias de “estruturas sem história, da história sem sujeito, das teorias sem verdade e do fim das tentativas de explicação racional do mundo e das relações sociais". 9

Levamos essas premissas em consideração ao definir o arcabouço teórico que norteou o nosso trabalho. Encontramos no pensamento crítico de matriz marxista contribuições que muito nos auxiliaram a compreender e analisar de forma ampla a problemática concreta a que nos propusemos, cientes de que nosso trabalho não goza do privilégio de estar fora das contradições da sociedade, cabendo se posicionar diante desta realidade. É com esse entendimento que buscamos compreender e fazer uso do conceito de hegemonia conforme problematizado por Antonio Gramsci. Neste capítulo, abordaremos os conceitos de hegemonia, sociedade civil, Estado, ideologia e imaginário social com base nesta estrutura teórica. Também neste capítulo tentaremos algumas definições sobre o direito à comunicação, meios de comunicação, TV pública e políticas públicas. Iniciaremos pelo conceito de hegemonia.

\section{1- Hegemonia}

O conceito de hegemonia ${ }^{10}$ adquiriu na figura de Antonio Gramsci ${ }^{11}$ uma espécie de emblema, muito embora não tenha sido ele seu primeiro formulador. Segundo a pesquisadora Buci-Glucksmann, o conceito de hegemonia é uma noção bastante usual na história do marxismo, sendo encontrado em escritos de Lênin, Bela Kun, Varga, Stalin e Bukhárin. Ela afirma que as estreitas ligações com as quais este conceito aparece, seja o de ditadura do proletariado, o de aparelho de hegemonia ou como constituição de classe, como hegemonia de

\footnotetext{
${ }^{9}$ ANDERSON, Perry. El pensamiento tíbio: Una mirada crítica sobre la cultura francesa. Revista latino americana de Ciencias Sociales. Año 1, no. 1 (jun. 2008). Buenos Aires : CLACSO, 2008.

${ }^{10} \mathrm{Em}$ seu sentido etimológico, o termo hegemonia deriva do grego eghestai ou eghemoneuo, que significam conduzir, ser guia ou estar à frente, comandar. Na Grécia Antiga, hegemônico era o chefe militar, o comandante do exército.

${ }^{11}$ É importante lembrar que a produção teórica de Gramsci tem sido objeto de diversos estudos, debates e disputas dentro e fora da academia, tendo se consolidado a partir dos anos 1960 com as primeiras edições de seus livros. Sobre os debates, as disputas e a recepção das ideias de Gramsci no Brasil, ver: SECCO, Lincoln. Gramsci e o Brasil: recepção e difusão de suas ideias. São Paulo: Cortez, 2002.
} 
Estado em seu sentido integral, ${ }^{12}$ representam um salto qualitativo na produção gramsciana, alertando para a necessidade de, na leitura das obras do pensador italiano, se eliminar as "barreiras artificiais que isolam os Cadernos do Cárcere dos Escritos políticos e da Terceira Internacional". 13

Já Hugues Portelli lembra o fato de que Gramsci atribuía a Lênin a origem da noção de hegemonia quando afirma em seus escritos do cárcere que "o princípio teóricoprático da hegemonia é a maior contribuição teórica de Ilitch à filosofia da práxis". ${ }^{14}$ Nesta mesma direção, Portelli lembra um texto em que Stalin atribui a Lênin uma formulação do conceito de hegemonia similar à elaborada por Gramsci. ${ }^{15}$ Mas ressalta, no entanto, que caberia redefinir o aporte específico feito pelo teórico italiano ao conceito, o que poderia estar relacionado a uma discussão sobre o capitalismo em países desenvolvidos, que demandava a busca de novas vias na luta pelo socialismo, basicamente a "guerra de posição", a qual exigiria um peso maior nas disputas pela hegemonia.

Ao fazer uma breve história da fortuna crítica do conceito de hegemonia, Guido Liguori diz que coube a Norberto Bobbio uma leitura em que a ênfase gramsciana do conceito de hegemonia esta no aspecto cultural, e isso é a sua novidade. Segundo ele, para Bobbio "a diferença essencial, a peculiaridade da hegemonia gramsciana estava, coerentemente com sua visão de sociedade civil, no deslocamento de ênfase para a direção cultural: Se até 1926 o termo surgia, inclusive em Gramsci, com o mesmo significado em que é encontrado na tradição leninista (isto é, 'no sentido de direção política' da classe operária sobre as classes aliadas), nos Cadernos havia uma ampliação do conceito de hegemonia, que passava a significar também 'direção cultural'" ${ }^{16}$ Neste viés, todas as instituições da sociedade civil que desenvolvem alguma atividade de elaboração e divulgação cultural (ou seja, igreja, escolas, sindicatos etc.) detêm um papel na disputa pela hegemonia.

\footnotetext{
${ }^{12}$ BUCl-GLUCKSMANN, Christine. Gramsci e o Estado. Rio de Janeiro: Paz e Terra, 1980, p. 21.

${ }^{13}$ Idem. p.22.

${ }^{14}$ PORTELLI, Hugues. Gramsci e o bloco histórico. Rio de Janeiro: Paz e Terra, 1977, p. 61.

15 “Marx e Engels esboçaram, em grandes linhas, a idéia de hegemonia do proletariado. A contribuição de Lênin reside no fato de que ele desenvolveu esse esboço, transformando-o em um sistema completo de direção das massas trabalhadoras na cidade e no campo pelo proletariado, não somente para derrubada do tzarismo e do capitalismo, mas igualmente para a construção do socialismo sob a ditadura do proletariado" (Stalin). In: PORTELLI, Op.Cit. p. 62.

${ }^{16}$ LIGUORI Guido. Roteiros para Gramsci. Rio de Janeiro, Editora UFRJ, 2007, p. 209.
} 
Carlos Nelson Coutinho ${ }^{17}$ é a favor da vinculação do conceito de hegemonia gramsciano com a idéia de estratégia complexa e de longo alcance, caracterizada numa "guerra de posições". Ele afirma que Gramsci, partindo de observações feitas por Lênin sobre as dificuldades maiores para se conquistar o poder em países capitalistas mais desenvolvidos, analisou as diferenças estruturais entre formações econômico-sociais do 'Ocidente' e do 'Oriente', concluindo pela elaboração de estratégias apropriadas para cada uma delas. Essa estratégia de longo alcance se concretiza na necessidade da classe operária "fazer política", ou seja, alianças, e exercer a direção político-cultural dos que lutam contra o capitalismo.

Um dos estudos mais importantes sobre o conceito de hegemonia foi feito pelo italiano Luciano Gruppi ${ }^{18}$. Para ele, a idéia de hegemonia é o ponto de confluência entre Lênin e Gramsci que, no entanto, ao falar em reforma intelectual e moral, não se reduz aos aspectos da estrutura econômica e da organização política da sociedade, ampliando seu alcance também sobre as orientações ideológicas e as formas de pensar e conhecer. A ditadura do proletariado é, segundo Gruppi, "a forma política na qual se expressa o processo de conquista e de realização da hegemonia"19, sendo esta a "capacidade de direção, de conquistar alianças, capacidade de fornecer uma base social ao Estado proletário. Nesse sentido, pode-se dizer que a hegemonia do proletariado realiza-se na sociedade civil, enquanto a ditadura do proletariado é a forma estatal assumida pela hegemonia". ${ }^{20}$ Com efeito, o caráter leninista do conceito de hegemonia é relevante para Gruppi, onde se destaca a direção da ditadura do proletariado e a capacidade de dirigir um grupo de aliados, ou seja, os aspectos de direção e de domínio. Liguori ${ }^{21}$ lembra que Luciano Gruppi definiu a hegemonia como "a capacidade de dirigir, de conquistar alianças, capacidade de fornecer uma base social ao Estado proletário", mas também é um "fato cultural, moral, de concepção de mundo", com o propósito de construir um bloco histórico.

Nos Cadernos do Cárcere ${ }^{22}$ Gramsci define o conceito de hegemonia como a capacidade de liderança ideológica e cultural exercida por uma classe em determinado momento histórico. A conquista desta capacidade de liderança é um processo histórico longo,

\footnotetext{
${ }^{17}$ COUTINHO, Carlos Nelson. Gramsci: um estudo sobre seu pensamento político. Rio de Janeiro: Civilização Brasileira, 2007, p. 63-65.

${ }^{18} \mathrm{GRUPPI}$, Luciano. O conceito de hegemonia em Gramsci. Rio de Janeiro: Graal, 1978, p. 5.

${ }^{19}$ Ibidem.

${ }^{20}$ Ibidem.

${ }^{21}$ Cf. LIGUORI, op. cit. p. 210.

22 Utilizamos aqui a edição da editora Civilização Brasileira organizada por Carlos Nelson Coutinho, Marco Aurélio Nogueira e Luiz Sergio Henriques publicada em seis volumes entre os anos de 1999 e 2002.
} 
que pode e deve ser preparado por uma classe e consolidado nos embates sociais e disputas por posições, inclusive no plano ético-cultural, visando a conquista da direção cultural e ideológica. Para Gramsci,

O fato da hegemonia pressupõe indubitavelmente que sejam levados em conta os interesses e as tendências dos grupos sobre os quais a hegemonia será exercida, que se forme um certo equilíbrio de compromisso, isto é, que o grupo dirigente faça sacrifícios de ordem econômico-corporativa; mas também é indubitável que tais sacrifícios e tal compromisso não podem envolver o essencial, dado que, se a hegemonia é ético-política, não pode deixar de ser também econômica, não pode deixar de ter seu fundamento na função decisiva que o grupo dirigente exerce no núcleo decisivo da atividade econômica. $^{23}$

Para Gramsci o equilíbrio de compromisso deve ser construído expressando a vontade política como "consciência operosa da necessidade histórica, como protagonista de um drama real e efetivo", ${ }^{24}$ o que deve ser feito sem esquecer a importância do trabalho de crítica do passado, visando modificações nos modos de pensar, nas crenças e nas opiniões, o que

não ocorre mediante "explosões" rápidas, simultâneas e generalizadas, mas sim, quase sempre, através de "combinações sucessivas" (...). A ilusão "explosiva" nasce da ausência de espírito crítico. (...) Na esfera da cultura, aliás, as "explosões" são ainda menos frequentes e menos intensas do que na esfera da técnica, na qual uma inovação se difunde, pelo menos no plano mais elevado, com relativa rapidez e simultaneidade. ${ }^{25}$

Nosso entendimento do conceito de hegemonia esta mais próximo do que o associa à capacidade de liderança ideológica e cultural de uma classe sobre outras, o que pode ser obtida e solidificada em meios às disputas e embates sociais envolvendo desde os planos econômico e político, até as concepções de mundo, ideologias e símbolos culturais. Como afirma o professor Dênis de Moraes, as tensões e utopias do imaginário social fazem parte do campo de batalhas ideológicas pela hegemonia cultural, que se traduzem nos jogos de consenso e dissenso da difusão simbólica. A conquista do consenso não se reduz à coerção e ao uso da força, mas também à capacidade de que um bloco histórico dirija moral e culturalmente a sociedade, o que pressupõe uma correta interpretação da realidade. ${ }^{26} \mathrm{~A}$ conquista da hegemonia ocorre em um processo de obtenção gradual do consenso e de

\footnotetext{
${ }^{23}$ GRAMSCl, Antonio. Cadernos do cárcere. Org. de Carlos Nelson Coutinho, Marco Aurélio Nogueira e Luiz Sergio Henriques. Rio de Janeiro, Civilização Brasileira, 2000, p. 48, v.3.

${ }^{24}$ Idem, v.3, p. 17.

${ }^{25}$ Idem, v. 2, p. 207.

${ }^{26}$ Cf. MORAES, op. cit. p. 35 .
} 
articulação de forças heterogêneas, num intenso trabalho de persuasão e de penetração cultural no interior da sociedade, de onde deriva a possibilidade de que um grupo social se torne dirigente antes mesmo de conquistar o poder, o que, quando ocorre, o transforma também em grupo dominante. ${ }^{27}$ É importante perceber que essa formulação implica numa 'superação' do conceito de Estado como sociedade política ou reduzido ao aparelho coercitivo apenas, abrindo espaço para a distinção entre duas esferas no interior das superestruturas, sendo elas a sociedade política e a sociedade civil. Estas duas esferas se diferenciam pelo papel que desempenham na reprodução das relações de poder.

\section{2- Sociedade civil}

A sociedade civil, na definição gramsciana, é o espaço político por excelência, ou o "teatro da história", no dizer de Marx. ${ }^{28}$ Para o nosso estudo, essa definição se reveste de grande relevo devido ao fato de que os meios de comunicação têm na sociedade civil o seu principal campo de atuação.

O resgate da importância que esse conceito alcança no pensamento de Grasmci se deve, em grande medida, aos trabalhos de Norberto Bobbio (1999), principalmente o texto em que discute sobre Gramsci e a sociedade civil, considerando-o a chave para o entendimento das ideias do pensador italiano. Para Bobbio, a definição deste conceito marcaria uma autonomia de Gramsci em relação ao marxismo ao estabelecer na superestrutura, ou seja, na cultura e no mundo das ideias, o local dos embates, do "teatro da história". Em Marx, esse embate faz parte do momento estrutural, identificado com a base material e a infra-estrutura econômica da sociedade. ${ }^{29} \mathrm{Na}$ interpretação de Bobbio, o momento ético-político passava a ter uma preponderância tal na teoria de Gramsci que o fazia classificar como sendo o teórico da superestrutura. No entanto, como resgata Liguore, ${ }^{30}$ apesar de haver em Gramsci um peso para a política e para subjetividade, ele o faz sem perder de vista os momentos de unidade e de autonomia, assim como de ação recíproca e dialética entre os níveis de realidade, mas enriquecendo a teoria marxista com a proposição não-mecanicista de que as contradições derivadas das relações sociais de produção, expressas em suas estruturas e superestruturas,

\footnotetext{
${ }^{27}$ Idem.

${ }^{28}$ MARX, Karl. A ideologia alemã. São Paulo: Boitempo, 2007, p. 45.

${ }^{29}$ Cf. LIGUORE, p. 40.

${ }^{30}$ Idem, p. 41.
} 
formam o que denominou de bloco histórico. Essa conclusão de Liguore elimina a possibilidade de idealismo na concepção gramsciana de sociedade civil.

Gramsci distingue no interior das estruturas do bloco histórico a esfera da sociedade civil, na qual se desenvolve a direção "moral e intelectual" de um sistema social, e a esfera da sociedade política, que agrupa os aparelhos de Estado. As duas esferas mantêm, diz Portelli (1977), relações permanentes, de complementaridade, pois "não existe sistema social em que o consentimento seja a base exclusiva da hegemonia, nem Estado em que um mesmo grupo possa, somente por meio da coerção, continuar a manter de forma durável a sua dominação". Exemplo dessa relação entre coerção e consenso é a elaboração da opinião pública pele Estado no sentido de garantir o consenso em torno de seus atos. Para Gramsci,

O que se chama de "opinião pública" esta estreitamente ligado à hegemonia política, ou seja, é o ponto de contato entre a "sociedade civil" e a "sociedade política", entre o consenso e a força. O Estado, quando quer iniciar um ação pouco popular, cria preventivamente a opinião pública adequada, ou seja, organiza e centraliza certos elementos da sociedade civil.

A opinião pública é o conteúdo político da vontade política pública, que poderia ser discordante: Por isto, existe luta pelo monopólio dos órgãos de opinião pública - jornais, partidos, Parlamento -, de modo uma só força modele a opinião e, portanto, a vontade política nacional, desagregando os que discordam numa nuvem de poeira individual e inorgânica. ${ }^{31}$

O papel desempenhado pela ‘imprensa marrom’ e pelo rádio (na época não havia TV) já se apresenta para Gramsci como forma de manipulação da opinião pública, visando favorecer o consenso em torno dos atos de uma classe dominante.

Uma definição importante para os conceitos de sociedade política e sociedade civil é em relação às suas funções na organização da vida social e na reprodução das relações de poder. Embora constituam o Estado e objetivem conservar ou promover os interesses de uma classe hegemônica, é no seio da sociedade civil que as classes procuram ganhar aliados através da direção política e do consenso, ou seja, exercer a sua hegemonia. No âmbito da sociedade política elas exercem a sua dominação mediante a coerção e a ditadura. Coutinho (2007) destaca que, além do aspecto funcional, existe também uma distinção decorrente da materialidade de cada esfera. Enquanto a sociedade política se materializa nos aparelhos repressivos de Estado (burocracia estatal etc,), a sociedade civil tem seus portadores,

${ }^{31}$ GRAMSCl, op cit. v. 3, p. 265. 
no que Gramsci chama de 'aparelhos privados de hegemonia', ou seja, organismos sociais coletivos voluntários e relativamente autônomos em face da sociedade política. Gramsci registra o fato novo de que a esfera ideológica, nas sociedades capitalistas avançadas, mais complexas, ganhou uma autonomia material (e não só funcional) em relação ao Estado em sentido restrito (Coutinho, 2007, p. 129).

É a partir da análise das sociedades centrais e periféricas da economia capitalista ${ }^{32}$ que Antonio Gramsci propõe que o grau de coerção ou de consenso não é o mesmo em cada uma delas, ou não tem a mesma intensidade, em todas elas. Seus estudos o levam a determinar que em uma sociedade periférica o grau de coerção é maior, diferentemente de uma sociedade capitalista central, onde as formas de consenso $^{33}$ são mais expressivas. Essa sua análise que implica numa dupla perspectiva para a ação política tem inspiração e correspondência na natureza da figura do Centauro, de Maquiavel, que presume em sua constituição (cabeça de homem e corpo de animal) um aspecto ferino e outro humano em um mesmo corpo, com os significados de força e consenso, violência e civilidade. A metáfora centaurina serve então para uma distinção importante na construção do seu conceito de hegemonia, ancorado numa possibilidade mais complexa de atuação do Estado que, seja através da coerção ou do consenso, expressa, em sua concepção dialética e ampliada uma relação dinâmica de unidadedistinção entre Estado e sociedade civil.

No entender do professor Dênis de Moraes (2009), ao distinguir as duas esferas que atuam no interior das superestruturas, Gramsci supera o conceito de Estado como aparelho de coerção. A sociedade política fica reduzida ao aparelho estatal burocrático e ao de coerção responsável por assegurar a disciplina dos que não consentem, atuando nos momentos de crise no comando e na direção. Já a sociedade civil é o "espaço político por excelência, lugar de forte disputa de sentidos. Engloba o conjunto de ideologias que atravessam o real histórico procurando estabelecer a sua potência, isto é, a sua capacidade de mobilização política e, finalmente, sua realização histórica". ${ }^{34}$ Nesse sentido, a sociedade civil é o espaço

\footnotetext{
${ }^{32}$ Cf. COUTINHO, p. 129. Essa discussão sobre as disputas hegemônicas nas sociedades capitalistas mais complexas vai determinar um aspecto fundamental da estratégia gramsciana de "guerra de posições ou de movimento" e da elaboração da idéia de transição como processo, assunto que mereceu uma atenção importante nesta obra de Coutinho, principalmente no que se refere à polêmica com Althusser.

${ }^{33}$ De acordo com Raymond Willians, não é fácil o uso da palavra consenso. Sua popularização aconteceu no séc. XX, podendo se referir, em seu sentido político, a uma forma de eludir as diferenças de opinião ou também de se chegar a um termo médio. As dificuldades em seu uso na atualidade decorrem devido ao seu amplo espectro de significado, que inclui o sentido positivo de busca de concordância geral, o de assentimento passivo ou inconsciente e até mesmo o de manipulação que procura "construir uma 'maioria silenciosa' como base do poder". WILLIANS, Raymond. Palavras-chave. São Paulo, Boitempo, 2007, p. 108.

${ }^{34}$ MORAES, op. cit. p. 39.
} 
da hegemonia, onde se articulam interesses diversos, e não apenas os do Estado ou da classe dominante, o que faz com que se configure como a arena (ou o teatro da história), mas isso "nada tem a ver com interpretações liberais e social-democratas, segundo as quais seria um lugar de harmonização de interesses e de emergência de um 'terceiro setor' situado para além do Estado e do mercado". ${ }^{35}$ É neste mesmo sentido que Guido Liguori (2007) alerta para o fato de existir, no debate contemporâneo sobre o conceito de sociedade civil, uma tendência a fazer uma leitura errada de Gramsci e do seu conceito de Estado ampliado e renunciar ao entendimento do papel da sociedade política. Isso decorrente da ideia de que a mundialização econômica pressupunha um enfraquecimento do político-estatal. ${ }^{36}$

Para a nossa discussão sobre políticas públicas de comunicação é importante frisar o aspecto de que, embora na sociedade civil operem de forma quase autônoma os aparelhos privados de hegemonia, a exemplo da imprensa, os partidos políticos, a igreja, a escola, os sindicatos etc., também atuam na sociedade civil os aparelhos de hegemonia que são vinculados ao Estado, dando suporte e sustentação à sua ação política e difundindo as idéias da classe hegemônica. Como dizia Gramsci, o Estado pede consenso, mas também educa este consenso. Portanto, o aparelho de hegemonia esta ao alcance da classe dominante, mas também das classes que almejam disputar a hegemonia.

\section{3- Estado}

Sociedade civil mais sociedade política, hegemonia revestida de coerção, constituem o que Gramsci chamou de Estado integral (ou ampliado). É a partir da compreensão de que em seu tempo histórico as relações entre a sociedade civil e a sociedade política estavam mais desenvolvidas, que as relações entre a política e a economia atingem características singulares, que surge esta formulação. Gramsci faz isso, no entanto, sem perder de vista que o Estado é a expressão de uma situação econômica. Sua síntese de Estado ampliado é a junção dos aparelhos de coerção governamentais mais os aparelhos hegemônicos, ou seja, na arena em que se constitui a sociedade civil as batalhas hegemônicas não se reduzem às batalhas de ideias, mas da existência de aparelhos com o objetivo de forjar o consenso em torno das ideias da classe no poder.

\footnotetext{
${ }^{35}$ Cf. MORAES, p. 39.

${ }^{36}$ Cf. LIGUORI, p. 49-50.
} 
Essa formulação difere da que Althusser ${ }^{37}$ propõe em sua tentativa de formular um conceito teórico sobre o Estado. Segundo ele, o aparelho repressivo é o centro do Estado, que também possui diversos aparelhos ideológicos, cada um com uma lógica interna própria. A função do Estado é reproduzir as relações de produção, motivo maior de suas ações. Em sua definição, portanto, há uma ligação vital entre os aparelhos ideológicos e o Estado.

Essa diferenciação é importante, pois determina estratégias de luta pelo poder e pela hegemonia. De acordo com Dênis de Moraes, ${ }^{38}$ o conceito gramsciano de aparelho privado de hegemonia não se confunde com o de Althusser sobre os aparelhos ideológicos de Estado que, em Althusser, implica numa ligação umbilical entre Estado e aparelhos, sem o nível de autonomia dos aparelhos privados proposto por Gramsci. E é exatamente essa autonomia que abre a possibilidade de que as classes subalternas alcancem a hegemonia antes de conquistar o poder de Estado. Se para Gramsci o Estado ampliado é a união entre Estado e essas instituições de hegemonia, para Althusser essas instituições já são aparelhos de Estado, numa relação imutável. Isso faz com que para Althusser a luta pela hegemonia se trave fora do Estado em seu sentido amplo, ou seja, a hegemonia é algo próprio do Estado, com o objetivo de assegurar a dominação e não um fruto de seu processo. Para Gramsci existe uma sucessiva batalha hegemônica no interior da sociedade civil, o Estado ampliado, durante o processo de luta pelo poder. Deste diagnóstico decorre a proposta de uma estratégia de longa marcha, fincada na práxis política, ao invés de um choque frontal com o Estado.

Para Gramsci, o Estado integral "é atravessado pela luta de classes, os processos nunca são unívocos, ele também constitui o terreno do embate de classes. Existe luta entre duas hegemonias, sempre". ${ }^{39}$ Ou seja, o Estado, dialeticamente, é instrumento de classe, mas também o lugar de luta de classes pela hegemonia.

Não se devem confundir as concepções de Gramsci com a ideia de autonomia que "pinta a sociedade civil como uma arena livre em que os atores, dialogando, criam o tecido conectivo da convivência democrática". ${ }^{40}$ Ao contrário, para Gramsci as opiniões nascem de um centro de irradiação e difusão, e não do cérebro individual das pessoas, porque o Estado é educador e uma de suas funções é "elevar a grande massa da população a um determinado nível cultural e moral, nível que corresponde às necessidades de desenvolvimento das forças

\footnotetext{
${ }^{37}$ ALTHUSSER, Louis. Aparelhos ideológicos de Estado. Rio de Janeiro: Graal, 1983.

${ }^{38}$ Cf. MORAES, op. cit., p. 40-41.

${ }^{39}$ GRAMSCI, apud LIGUORI, op. cit. p. 29.

${ }^{40}$ Cf. LIGUORE, op. cit., p. 31.
} 
produtivas e, portanto, aos interesses das classes dominantes". ${ }^{41}$ O Estado é o organizador das atividades superestruturais, como os meios de comunicação, a escola, a igreja, os sindicatos e partidos, agindo para criar conformismo, sem deixar a sociedade civil relegada a própria espontaneidade. ${ }^{42}$ É educador na medida em que

tende precisamente a criar um novo tipo ou nível de civilização; como isso acontece? Dado que se opera essencialmente sobre forças econômicas (...), não se deve extrair a conseqüência de que os fatos de superestrutura sejam abandonados a si mesmos, a seu desenvolvimento espontâneo, a uma germinação casual e esporádica (apud Liguori, 2007).

A relação entre sociedade política e sociedade civil é marcada pelo papel relevante dos aparelhos hegemônicos, onde tem importância considerável a atuação desenvolvida pelos intelectuais. Dessa forma, aos aparelhos de coerção, típicos da sociedade política, somam-se as diversas organizações de caráter "privado" que compõem a sociedade civil no sentido de garantir a hegemonia da classe dominante. O Estado é mais do que um monopolizador das estruturas e meios de coerção física, constituíndo-se também de uma série de instituições que atuam no âmbito da sociedade civil e trabalham diretamente com os embates e disputas culturais e ideológicas que existem no seio da sociedade como um todo. Ou seja, o Estado, de acordo com Gramsci, serve tanto para ser dominante quanto para ser dirigente, tanto para exercer a coerção quanto para exercer a hegemonia. Para Guido Liguori (2007), o marxismo de Gramsci impede uma distinção nítida e orgânica da sociedade civil como sendo uma estrutura ou um "sistema de carecimentos" hegeliano, pois, para ele,

O Estado é o sujeito da iniciativa político-cultural, mesmo agindo, como sabemos, seja por meio de canais explicitamente públicos, seja por meio de canais aparentemente privados. A capacidade heurística deste esquema interpretativo mostra-se ainda mais evidente hoje, quando o desenvolvimento dos mass media e sua incidência político-cultural são tão amplamente reconhecidos. De fato, aos velhos "aparelhos hegemônicos", como a escola ou a imprensa, somou-se a televisão - fundamental na criação do senso comum - terreno em que muitas vezes as conotações de "publico" ou "privado", de "político" ou "econômico" encontram muitas dificuldades (Liguori, 2007, p.22-23).

\section{4- Ideologia}

\footnotetext{
${ }^{41}$ GRAMSCl, apud LIGUORI., op. cit., p. 31.

42 Perry Anderson identifica no sistema parlamentar o "eixo do aparelho ideológico do capitalismo", atribuindo à igreja, partidos políticos, escola e meios de comunicação apenas um papel complementar. In: EAGLETON, Terry. Ideologia. São Paulo, Editora Unesp/Editora Boitempo, 1997, p. 105.
} 
Polissêmica, a palavra "ideologia" tem sido motivo de estudos nas mais diversas correntes de pensamento das ciências humanas, abrangendo, de acordo com Terry Eagleton (1997) uma ampla variedade de significados, ${ }^{43}$ muitos deles incompatíveis entre si ou mesmo pejorativos. Alguns autores se aproximam na afirmação de que essa diversidade de significados reflete as desavenças entre as duas diferentes concepções da realidade social, o modelo estrutural marxista e o tipológico weberiano. De acordo com Eagleton, o núcleo central de pensadores do marxismo esteve muito preocupado com "ideias de verdadeira e falsa cognição, com ideologia como ilusão, distorção e mistificação; já uma outra tradição de pensamento, menos epistemológica que sociológica, voltou-se mais para a função das ideias na vida social do que para seu caráter real ou irreal". Essa divisão também se encontra em Pierre Bourdieu (2007), que coloca de um lado os que encaram os fatos culturais como estrutura estruturada e não como estrutura estruturante, derivando daí uma ênfase na análise interna das mensagens de natureza simbólica. Do outro lado, os que reforçam o caráter alegórico dessas mensagens, determinado pelas condições de existência econômica e política. $^{44}$

Há ainda a escola de pensamento americana que afirma que as ideologias são um esquema fechado de crenças, uma forma esquemática e inflexível de ver o mundo, que Eagleton classifica de ideologia do fim da ideologia. ${ }^{45}$ Ideologia também foi associada aos modos pelos quais o significado "contribui para manter as relações de dominação", nas palavras de John Thompson. Ou teve o seu âmbito ampliado de tal forma que tudo passa a ser ideológico, ou ideologia, como na teoria foucaultiana dos micro-poderes. "Fiéis a essa lógica, Foucault e seus seguidores abandonaram por completo o conceito de ideologia, substituindo-o por um 'discurso' mais capaz". ${ }^{46}$ Descartando as questões epistemológicas e a busca do

\footnotetext{
${ }^{43}$ Terry Eagleton lista: a) o processo de produção de significados, signos e valores na vida social; b) um corpo de idéias característico de um determinado grupo ou classe social; c) idéias que ajudam a legitimar um poder político dominante; d) idéias falsas que ajudam a legitimar um poder político dominante; e) comunicação sistematicamente distorcida; f) aquilo que confere certa posição a um sujeito; g) formas de pensamento motivadas por interesses sociais; $h$ ) pensamento de identidade; i) ilusão socialmente necessária; j) a conjuntura de discurso e poder; k) o veículo pelo qual atores sociais conscientes entendem o seu mundo; l) conjunto de crenças orientadas para a ação; $m$ ) a confusão entre realidade lingüística e realidade fenomenal; $n$ ) oclusão semiótica; o) o meio pelo qual os indivíduos vivenciam suas relações com uma estrutura social; p) o processo pelo qual a vida social é convertida em uma realidade natural. IN: EAGLETON, op. cit. p. 15-16.

${ }^{44}$ Para Marx, "sempre se deveria distinguir entre a transformação material das condições econômicas de produção (...) e as formas legais, políticas, religiosas, estéticas ou filosóficas - em resumo, ideológicas - pelas quais os homens se conscientizam desse conflito e lutam para resolvê-lo". Apud: WILLIANS, op. cit. p. 215. ${ }^{45}$ Idem, p 18.

${ }^{46}$ Idem, p. 21.
} 
verdadeiro ou do falso implícito neste conceito, Althusser (1983) propõe que a ideologia seja definida ou representada pelo que a pessoa vivencia em suas relações com a sociedade.

Em síntese, o debate sobre o significado da palavra ideologia poderia ser resumido entre a concepção que a classifica como falsa consciência e a que afirma que ela é uma concepção de mundo. Gramsci, assim como Lenin, pode ser situado nesta segunda proposição. Lenin diz que "a questão pode ser posta somente assim: ou ideologia burguesa, ou ideologia socialista. Não há via intermediária” ${ }^{47}$ Gramsci debate a ideologia vinculando este conceito ao de hegemonia, na medida em que propõe que a estrutura ideológica da classe dominante é a organização material responsável por manter, defender e desenvolver a sua dominação, ou seja, a ideologia faz parte de um complexo de "trincheiras" e "fortificações" da classe dominante. Embora considere a imprensa a parte mais dinâmica dessa estrutura ideológica, mesmo ela não sendo a única, pois dela fazem parte também a igreja, a escola, bibliotecas, e até mesmo os nomes de rua. De acordo com Liguori, a ideologia é, em Gramsci,

a representação da realidade própria de um grupo social. O sujeito individual tem uma visão própria do mundo, que não é só sua, mas também do grupo do qual faz parte; ou muitas vezes sincreticamente, participa de várias visões do mundo. As ideologias são o terreno em que os homens se movem. Os sujeitos coletivos são definidos pelas ideologias. Sem ideologia, não há sujeito. A ideologia é o lugar de constituição da subjetividade coletiva, mas também - de modo mais contraditório - da individual, no âmbito da luta hegemônica (Liguori, 2007, p. 94-95).

Uma definição que nos auxiliará neste trabalho é a que foi feita por Marilena Chauí, quando afirma que nas sociedades divididas em classes o discurso ideológico tem a função de realizar a

lógica do poder fazendo com que as divisões e as diferenças apareçam como simples diversidade das condições de vida de cada um, e a multiplicidade das instituições (...) apareça como um conjunto de esferas identificadas umas às outras, harmoniosa e funcionalmente entrelaçadas, condição para que um poder unitário se exerça sobre a totalidade social e apareça, portanto, dotado de aura da universalidade, que não teria se não fosse obrigado a admitir realmente a divisão efetiva da sociedade em classes (Chauí, apud Moraes, p. $30)$.

Para nós, ideologia será encarada como sendo uma concepção de mundo, partilhada por uma classe social, concepção que é construída a partir de uma estrutura ideológica representada nos meios de comunicação, na escola, igreja entre outras formas de influir e consolidar, de forma direta ou indireta, a opinião das pessoas.

\footnotetext{
${ }^{47}$ V. I. LENIN. Que fazer? IN: Obras escolhidas. São Paulo: Alfa-Omega, 1979, p. 165.
} 


\section{5- Imaginário social}

O imaginário social é visto aqui como uma dimensão da vida coletiva fundada na simbologia imagética, através da qual as visões de mundo, assim como as aspirações e esperanças de um povo procuram se expressar. Dele fazem parte as ideologias, os símbolos, rituais e mitos representativos de uma comunidade. De acordo com Baczko,

El nacimiento y la difusión de signos llenos de imágenes y ritos colectivos, refleja la necesidad de encontrar un lenguaje y un modo de expresión que corresponda a una comunidad de imaginación social, asegurando un modo de comunicación a las masas que intentan darse una identidad colectiva, reconocerse y afirmarse en sus acciones. Pero, por otro lado ese mismo simbolismo y ritual ofrecen un decorado y un suporte a los poderes que sucesivamente se instalan y que intentan estabilizarse. En efecto, es notable el hecho de que las élites políticas se den rápidamente cuenta de que el dispositivo simbólico constituye un instrumento eficaz para influir y orientar la sensibilidad colectiva, para impresionar a la muchedumbre y hasta manipularla (backzo, 1984, p. 44).

Através do imaginário uma coletividade constrói sua identidade e distribui os papéis e posições sociais, compartilha seu modo de ser e organiza seus objetivos, além do que, em seus processos descontínuos, possibilita que surjam novas concepções e modelos de comportamento. Através dos símbolos podemos descobrir o que esta por trás da organização da sociedade e do próprio entendimento da sua história. "As significações despertadas por tais imagens estabelecem referencias que definem, para os integrantes de uma mesma comunidade, os meios inteligíveis de seus intercâmbios com as instituições e sua compreensão da realidade". ${ }^{48}$ Nesse sentido, necessita de um código que viabilize a comunicação, função desenvolvida pela linguagem que, na verdade, muito mais do que um código de regras, é um conjunto de conceitos. Para Castoriadis (1982), a linguagem é onde primeiro se encontra o simbólico. ${ }^{49}$ Os elementos culturais e as referências que buscamos para construir os nossos interesses, visões e concepção de mundo, tudo isso tem seus traços já expressos na linguagem que usamos.

\footnotetext{
${ }^{48}$ MORAES, op. cit. p. 31.

${ }^{49}$ Mas é nas instituições o lugar onde Castoriadis destaca a importância do simbólico. Para ele, "As instituições não se reduzem ao simbólico, mas elas só podem existir no simbólico, são impossíveis fora de um simbólico em segundo grau e constituem cada qual a sua rede simbólica". (...) “As sentenças do um tribunal são simbólicas e suas conseqüências o são quase que integralmente, até o gesto do carrasco que, real por excelência, é imediatamente também simbólico em outro nível". CASTORIADIS, Cornelius. A instituição imaginária da sociedade. Rio de Janeiro: Paz e Terra, 1982, p. 142.
} 
As finalidades das instituições e a funcionalidade dos processos sociais são estabelecidas pelo sistema simbólico quando unifica o imaginário de uma coletividade. De acordo com Moraes,

Através de múltiplos imaginários, uma sociedade traduz percepções que coexistem ou se excluem enquanto forças reguladoras do cotidiano. A imaginação revela-se então como um dos modos pelos quais a consciência encara a vida, elabora ou a contesta. Motiva o homem a perseguir anseios, a cultivar expectativas, a predispor-se para o que ainda na está dado, a sair de si, enquanto molécula isolada, em direção ao que o atrai no âmbito da manifestação social. A imaginação contribui para liberar-nos da evidencia do presente imediato e tantas vezes insatisfatório ou desfavorável, motivandonos a explorar possibilidades que existem virtualmente e podem até ser materializadas no curso de embates e realinhamentos (Moraes, op. cit. p. 32$33)$.

Para nós, a definição de imaginário social estará dentro desta análise que a define como sendo o conjunto de múltiplas percepções partilhadas em um determinado momento histórico por uma coletividade, representando as formas como esse grupo se apropria do mundo que vivencia.

\section{6- Políticas públicas}

Para nossa discussão, política pública é definida aqui como o conjunto de ações desencadeadas pelo Estado com vistas ao atendimento a demandas da sociedade civil e podem ser desenvolvidas em parcerias com organizações não governamentais ou com a iniciativa privada.

Embora este seja um conceito discutido em diversas áreas do conhecimento, é no âmbito das ciências políticas que sua teorização ganha corpo, variando seu entendimento conforme a escola de pensamento. Para alguns autores, a política pública é vista como um conjunto de medidas de equilíbrio de orçamento entre receitas e despesas, para outros, uma política de gastos, ou ainda uma forma de inclusão e de compensação para os desníveis estruturais nos países em desenvolvimento.

De acordo com SOUZA (2006), as políticas públicas estão vinculadas ao Estado, porque este detém a atribuição de definir o como os recursos serão aplicados para o beneficio da população. FERNANDES (2007) localiza a política pública como a manifestação de algo entre o administrativo e o político, este por estar ligado aos processos decisórios. Outros autores, os de vertente marxista, definem as políticas públicas como mecanismo de 
manutenção das classes hegemônicas no poder, visando apenas garantir a reprodução das forças de trabalho. $\mathrm{O}$ fato de nem sempre ter à sua frente um representante da classe dominante, podendo inclusive ser este um membro da classe dominada, se explica na ideia de autonomia relativa do Estado, desenvolvida por POULANTZAS (1985), pois embora não tenha sempre um legítimo representante à frente do Estado, a classe dominante vai ter sempre seus interesses defendidos por este. Para Poulantzas, é possível o Estado atender aos interesses econômicos das classes dominadas, e quando o faz é para defender, em última instância, os interesses das classes dominantes, mesmo que em algum nível tenha que sacrificar ocasionalmente alguns interesses econômicos das últimas. ${ }^{50}$

A partir desta ótica, a possibilidade de existir uma política pública esta sempre condicionada ao fato de que, em última instância, haja algum nível de ganho para o capital. Elas podem existir, mas como forma de garantir uma condição mínima para que as classes subalternas continuem reproduzindo o capital.

Diversas críticas foram feitas a esta concepção. BOBBIO (1979) afirma que, ao pensar o Estado apenas na sua forma instrumental, como aparelho repressivo a serviço da dominação da burguesia, ou mesmo como um reflexo de sua base estrutural, depara-se com as dificuldades para analisar as formas de governo. Outra vertente crítica à teoria marxista do Estado, que também se alia ao revisionismo desencadeado nos anos setenta, com o avanço neoliberal, é a feita pelos adeptos do neo-institucionalismo, estes partindo de uma recusa a uma abordagem dos processos históricos como determinações puramente societais. Para estes críticos, a pobreza da teoria marxista se expressa na impossibilidade de uma abordagem do Estado como um ator independente (Skocpol, 1985) capaz de explicar os fenômenos sociais e políticos.

No entanto, Poulantzas apresentou uma segunda formulação de sua teoria, em que define o Estado não mais a partir de suas funções, mas de sua natureza. Ele vai desenvolver

\footnotetext{
${ }^{50}$ De acordo com Marques (1997), na primeira formulação de Poulantzas o Estado cumpriria a dupla função de organizar a classe dominante, os capitalistas, e desorganizar a classe subalterna, os trabalhadores, estes apresentados na esfera política como cidadãos ao invés de vendedores de força de trabalho. Ou seja, o direito burguês e o aparelho de estado servem para dissimular a exploração de classe. O primeiro, ao ocultar a desigualdade social na sua base, já que, mesmo que possa existir igualdade jurídica, não quer dizer que esta corresponda a uma igualdade social. Ao negar a condição de classe, o direito burguês individualiza os agentes de produção. Já o Estado, ao apresentar-se o como representante de todos, produz um efeito de representação na unidade da sociedade e sua burocracia aparenta ser para todos, inclusive através da possibilidade de que todos tenham acesso ao seu aparelho, bastando ter competência para isso. É a idéia de que o burocratismo opera por uma lógica própria, ou seja, a lógica do burocratismo, que não é necessariamente fruto da classe dominante.
} 
sua análise do Estado capitalista numa perspectiva relacional de poder, quando define este não mais como uma forma objetiva, como aparelho de dominação de uma classe, nem também como um aparelho autônomo, de forma subjetiva. Não tendo uma estrutura homogênea nem impermeável aos embates e contradições que ocorrem na sociedade, o Estado passa a ser visto como sendo uma arena, um espaço de lutas entre as classes sociais.

Para nosso estudo, entendemos que as políticas públicas são o fruto das disputas pela hegemonia que ocorrem no interior da sociedade, ocasionando ao longo do processo histórico a afirmação dos direitos humanos como conquista a ser garantida pelo Estado através de sua regulamentação. No nosso caso, as políticas públicas de comunicação se inserem neste processo histórico como direito fundamental ainda carente de ações que positivem sua aplicação e garantia.

Além dos marcos regulatórios, e talvez mais importantes que eles, é necessário a definição de políticas públicas, de forma a garantir o papel do Estado como fomentador de iniciativas democratizantes. Políticas públicas entendidas como

Ações das instituições estatais de todo tipo, que, de acordo com as concepções e legitimações de cada sociedade e cada tempo histórico determinado, orientam os destinos da criação, produção, difusão e consumo de produtos comunicativos e culturais. $\mathrm{Na}$ atualidade, políticas de comunicação englobam também proposições e iniciativas de segmentos da sociedade civil e do setor privado (Bustamante, apud Moraes 2009, p. 109).

Papel do Estado, norteado pela perspectiva do interesse coletivo, da soberania e da defesa popular frente à subordinação aos gostos internacionais massivos e à comercialização lucrativa. É o uso e articulação dos meios na direção das redescobertas das histórias de nossa própria gente, no sentido em que falou Martín-Barbero (2008, p. 247), de representar "o mundo da cotidianidade, da subjetividade, da sexualidade (...) o mundo das praticas culturais do povo: narrativas, religiosas ou conhecimento." Questões comunicativas necessariamente dizem respeito a coletividades, aos interesses gerais da população, do publico, e por isso, a rigor, necessita de ação estatal e não poderia ficar submetido aos interesses privados.

Outro aspecto importante é compreender que o engajamento dos grupos sociais na agenda das discussões sobre políticas publicas é algo fundamental, e os encaminhamentos e debates estatais sobre o assunto também precisam passar pelas organizações populares e movimentos sociais de trabalhadores, mulheres, juventude, igrejas, trabalhadores do campo, artistas e intelectuais. 
Entre as principais tendências e propostas que têm sido debatidas sobre políticas públicas, algumas parecem sintetizar os anseios e perspectivas gerais. Entre elas esta a reorganização da comunicação estatal; a criação de novos canais públicos de televisão; a criação de leis que impeçam a concentração e garantam controle público sobre o uso do espectro; apoio às rádios e TVs comunitárias e alternativas; incentivo à produção cultural; leis que protejam e estimulem a indústria de audiovisual nacional, os programas regionais de coprodução, codistribuição e reserva de mercado para filmes, documentários e seriados de TVs latino-americanas.

\section{7- Direito à comunicação}

O debate sobre o direito à comunicação surgiu nos fóruns da UNESCO no idos dos anos 70 , propiciando uma das mais calorosas e acirradas polêmicas dentro de um foro da ONU. A riqueza desta discussão se deve em grande parte a multiplicidade de sentidos que a palavra 'comunicar' traz implicitamente, seja no âmbito pessoal ou coletivo. A linguagem, ${ }^{51}$ como uma forma de comunicação, tem na sua capacidade de estruturar o discurso um alicerce para a afirmação da humanidade enquanto coletivo, confundindo-se com o próprio processo de domínio da natureza. E ela é essencialmente dialógica. E esse fato era o que entrava em contradição com o livre fluxo de informação que, em mão única e sem dialogia, atendia aos interesses dos países detentores dos meios de comunicação e das agencias de informação em todo o mundo. Fazia-se necessário avançar.

O educador Paulo Freire (1983) já desenvolvera a ideia de impossibilidade de haver comunicação em uma via de mão única, baseando sua teoria na práxis e no diálogo, sem os quais não há comunicação. Discutindo sobre o processo de educar, ele afirma que esta, a comunicação, se constrói na busca de significação dos significados entre dois interlocutores, ativos e históricos, num diálogo vivenciado. A comunicação é para Paulo Freire a condicionante da humanização do ser humano, um

humanismo que não leve à procura de concretização de um modelo intemporal, uma espécie de idéia ou de mito, ao qual o homem concreto se aliene. Humanismo que, não tendo uma visão crítica do homem concreto, pretende um será para ele; ele que, tragicamente, está sendo uma forma de quase não ser. Pelo contrário, o humanismo (...) se baseia na ciência, e não

\footnotetext{
${ }^{51}$ Para Marx, a linguagem "é tão antiga quanto a consciência - a linguagem é a consciência real, prática, que existe para os outros homens e que, portanto, também existe para mim mesmo; e a linguagem nasce, tal como a consciência, do carecimento , da necessidade de intercâmbio com outros homens. Desde o inicio, portanto, a consciência já é um produto social e continuará sendo enquanto existirem homens"(MARX, 2007, p. 34.).
} 
na "doxa", e não no "eu gostaria que fosse" ou em gestos puramente humanitários. É, rejeita toda forma de manipulação, na medida em que esta contradiz sua libertação. ${ }^{52}$

É com base nesse pensamento dialógico que Jean D’Arcy em 1969 argumenta que a Declaração dos Direitos Humanos dá resposta de forma insuficiente, necessitando avançar em relação ao direito de informação, o que em sua compreensão já era possibilitado pelos avanços tecnológicos de então ${ }^{53}$, que faziam parecer "possível um novo passo adiante: o direito do homem à comunicação, derivado de nossas últimas vitórias sobre o tempo e o espaço, da mesma forma que da nossa mais clara percepção do fenômeno da comunicação (D’ARCY, 1969 apud UNESCO, 1983).

No entanto, o direito à comunicação nunca foi um consenso, sendo considerado pelas nações ocidentais detentoras dos monopólios de comunicação uma forma de ataque e censura à liberdade de imprensa e ao seu livre fluxo de informação. Nos fóruns da UNESCO esse debate ganhou dimensões de princípios, levando ao choque entre as posições antagônicas,em um debate que nunca foi finalizado. Mesmo assim, o relatório que resultou desse processo afirma claramente o direito de comunicar como sendo um direito humano fundamental, e que para garanti-lo seria "preciso dedicar todos os recursos tecnológicos de comunicação a atender às necessidades da humanidade a esse respeito (UNESCO, 1983). O relatório afirma também ser a democratização da comunicação um processo no qual o indivíduo passa a ser um elemento ativo, e não um simples objeto da comunicação, aumenta constantemente a variedade de mensagens intercambiadas, assim como também o grau e a qualidade da representação social na comunicação ou na participação (UNESCO, 1983). O

\footnotetext{
${ }^{52}$ FREIRE (1983), p. 49.pólios dos meios de comunicação

53 Um dos primeiros promotores do "direito à comunicação", Jean D’Arcy, delineou as etapas sucessivas que poderiam facilitar sua adoção: “Na época da ágora e do foro, na época da comunicação interpessoal direta, surge primeiro - conceito básico para todo o progresso humano e para toda civilização - a liberdade de opinião (...). O surgimento da imprensa, que foi o primeiro dos meios de expressão de massa, provocou, pela sua própria expansão e contra as prerrogativas de controles reais ou religiosas, o conceito correlato de liberdade de expressão (...). O século dezenove, que presenciou o extraordinário desenvolvimento da grande imprensa, caracterizou-se por lutas constantes em prol da liberdade (...). A chegada sucessiva de outros meios de comunicação de massa - cinema, rádio, televisão - da mesma forma que o abuso de todas as propagandas em véspera de guerra, demonstraram rapidamente a necessidade e a possibilidade de um direito mais preciso, porém mais extenso, a saber, o de procurar, receber e difundir as informações e idéias sem consideração de fronteiras (...) ou por qualquer procedimento. Hoje em dia parece possível um novo passo adiante: o direito do homem à comunicação, derivado de nossas últimas vitórias sobre o tempo e espaço, da mesma forma que da nossa mais clara percepção do fenômeno da comunicação (...). Atualmente, vemos que engloba todas as liberdades, mas que além disso traz, tanto para os indivíduos quanto para as sociedades, os conceitos de acesso, de participação, de corrente bilateral de informação que são todas elas necessárias,como percebemos hoje, para o desenvolvimento harmonioso do homem e da humanidade." (Le droit de I'homme à comunique, Documento no 39, da CIC, apud RAMOS 2007, p. 4).
} 
aprofundamento do debate fez com que se refletisse no relatório a necessidade de enfrentar o grave desequilíbrio e garantir uma

maior reciprocidade no fluxo de informação, condição favorável ao sucesso de uma paz justa e duradoura, e a independência econômica e política dos países em desenvolvimento, é necessário que sejam corrigidas as desigualdades no fluxo de informação com destino aos países em desenvolvimento, procedente deles e entre eles. Para tal fim, é essencial que os meios de comunicação de massa desses países disponham das condições e dos recursos necessários para fortalecer-se, estendendo-se a cooperação entre si e com os meios de comunicação de massa dos países desenvolvidos (UNESCO, 1983).

$\mathrm{Na}$ interpretação do professor Murilo Cesar Ramos (2007), o direito à comunicação deve ser visto como um direito social de quarta geração, mesmo que ainda não reconhecido como tal. Os direitos de primeira geração, surgidos no rastro das revoluções burguesas, seriam os direitos civis, que englobam as liberdades individuais, de pensamento, religião, reunião e a liberdade econômica, onde o Estado não pode se inserir. Já os direitos políticos seriam, que englobam as liberdades de associação em partidos e os direitos eleitorais, seriam os de segunda geração, estando vinculados ao processo de formação dos Estados. Os direitos sociais, que incluem o direito ao trabalho, ao estudo, saúde e assistência, além da liberdade da miséria e do medo, seriam os direitos de terceira geração, vinculados à emergência do Estadoprovidencia. No entanto, para Ramos o direito à informação, garantido entre os direitos da primeira geração, é um direito restrito e insuficiente.

O relatório MacBride foi, em sua visão, o momento alto da discussão sobre o direito à comunicação na UNESCO, sendo o relato mais completo já produzido sobre a importância da comunicação na contemporaneidade. Mas,

para o pensamento neoliberal que então começava seu período de hegemonia, era absurdo se pensar a comunicação na ótica de políticas nacionais. Mais absurdo ainda era pensar a comunicação como um direito mais amplo do que o consagrado, mas restritivo, direito à informação, do qual beneficiava-se fundamentalmente a imprensa, enquanto instituição, e seus proprietários privados, como agentes privilegiados de projeção de poder sobre as sociedades (RAMOS 2007).

O relatório sugere a necessidade da implementação de políticas públicas como forma de enfrentar o desequilíbrio das comunicações na América Latina. Muito embora tenha ocasionado debates e conferencias sobre o tema em todo o mundo, inclusive em nosso continente, a forte reação contrária, que incluiu até mesmo a saída dos Estados Unidos e da 
Inglaterra daquele organismo como forma de pressioná-lo, não viabilizou ações concretas no sentido de democratizar a comunicação, ocorrendo, com isso, que as políticas públicas ficassem apenas no papel.

Ao longo desse período, a mobilização em torno dessas bandeiras permitiu que fossem elaboradas narrativas midiáticas próprias no contexto da radiodifusão, não necessariamente endossados pela legislação e pela regulamentação, mas vinculados diretamente aos meios disponíveis e potencializados pela necessidade de comunicação. Incluem-se ai as rádios e TVs comunitárias, sindicais e de instituições de ensino e, mais recentemente, a redução de preços de equipamentos para a produção audiovisual e os avanços derivados da internet e da era digital. "Um movimento que se propõe a democratizar a comunicação não pode prescindir do entendimento da necessidade de que vários outros setores sociais compreendam o papel de componente central em suas lutas cotidianas assumido pela comunicação, fomentando ativismos pautados na reivindicação de políticas públicas inclusivas e de novas e diversificadas iniciativas - principalmente em atividades relacionadas à afirmação de lutas históricas; à mobilização e a capacitação de militantes e ativistas; ao necessário esclarecimento à sociedade sobre assuntos e acontecimentos deturpados pela mídia corporativa, dentre outros propósitos relevantes". ${ }^{54}$ Ainda dentro das perspectivas possíveis em que se articulam as comunicações na sociedade civil em que se caracteriza o processo de apropriação social das tecnologias de informação e comunicação (TICs), cabe lembrar a expressão "autocomunicação de massa", usada por Manuel Castells (2007) para definir o atual momento de disseminação do uso de computadores pessoais conectados à internet que, através de blogs, chats e redes sociais, abrem diversas possibilidades de comunicação. Um exemplo de atividade que tem conseguido algum espaço, embora limitado, tem sido o das web-rádio, como a Área de Rádios Livres das Américas (ARLA). ${ }^{55}$

Os movimentos que atuam na defesa da democratização da comunicação têm priorizado em suas ações a uma estratégia que coloca no centro a luta por medidas institucionais de regulamentação quem tornem o setor mais acessível, como as leis de radiodifusão, leis de TV a cabo e de rádios comunitárias. Em países como o Brasil, esse é um gargalo que elimina na fonte a possibilidade de qualquer meio alternativo possa disputar o

\footnotetext{
${ }^{54}$ CABRAL FILHO, Adilson V. "As políticas públicas de comunicação em busca de novos sujeitos históricos". IN: COUTINHO, Eduardo Granja (org). Comunicação e contra-hegemonia. Rio de Janeiro: editora UFRJ, 2008, p. 236-237.

${ }^{55}$ Disponível em: http://arla.radiolivre.org/
} 
espaço eletromagnético, devido a imensa quantidade de requisitos burocráticos e demais empecilhos, sem falar nas rádios comunitárias, que são perseguidas como criminosos de alta periculosidade. De acordo com o professor Fabio Konder Comparato, entre as ações necessárias para garantir a democratização das comunicações, "a primeira delas consiste em superar a carência legislativa. Nunca é demais relembrar que a supressão das liberdades fundamentais pode ocorrer, tanto pelo excesso, quanto pela ausência de leis. Nos regimes totalitários ou autoritários, as prescrições normativas são abundantes e minuciosas, e muitas delas vigoram secretamente, ao arbítrio dos que comandam. De modo que os cidadãos jamais sabem, ao certo, o que podem fazer sem sofrer sanções repressivas. Mas o vácuo legislativo, tão louvado pelo liberalismo hodierno, provoca a mesma supressão das liberdades, porque o terreno social se abre então, amplamente, à dominação sem limites dos ricos e poderosos". ${ }^{56}$

A participação do poder público nos sistemas de informação e difusão cultural, principalmente no que diz respeito a regulamentação das outorgas do uso do espaço eletromagnético, na descentralização das concessões de canais, no apoio às produções independentes, assim como através de políticas de fortalecimento da comunicação regional, são medidas que vem sendo problematizadas em diversos países. O caráter estratégico dessas medidas esta no papel que pode desempenhar a comunicação no fortalecimento da integração regional, do desenvolvimento cultural e da cooperação.

O significado dessas medidas pode ser dimensionado pela reação dos coronéis eletrônicos do Brasil, Argentina e Venezuela. A discussão sobre a regulamentação do setor é diariamente criminalizada e vendida à opinião pública como tentativa de "censura".

A Ley de Serviços Audiovisuais da Argentina, estabelece uma definição muito clara entre os setores público, privado comercial e o social, acabando com o desequilíbrio marcante que sempre favoreceu ao setor comercial privado. Com forma de incentivar a integração, a lei determina a inclusão da programação de sinais originados em países do MERCOSUR e em países latino-americanos, alem de estipular um percentual minimo de $60 \%$ de programação de origem nacional. Além disso, o Canal Encuentro se caracteriza pela mudança na lógica informática e cultural.

Essa lei pode transformar radicalmente o mapa dos meios locais, além de gerar múltiplas fontes de trabalho e garantir um acesso mais democrático às concessões de radiodifusão. Sua aplicação já gerou uma nova possibilidade de discussão sobre o papel social

\footnotetext{
${ }^{56}$ Disponível em: http://jus.uol.com.br/revista/texto/140/a-legitimidade-do-poder-de-reforma-constitucional
} 
dos meios de comunicação e, pela primeira vez na Argentina, discute-se que o espectro radioelétrico pertence a todos e que o setor privado não é proprietário do espaço comum, ainda que possa usá-lo. O grupo Clarín, que detém um monopólio ainda maior do que o da Rede Globo no Brasil, terá que se desfazer desse império.

Para a construção de uma perspectiva contra-hegemônica é determinante a materialização das formas que possibilitem a produção do consenso, disputando também no âmbito da sociedade civil a hegemonia cultural e o respaldo para esses processos. Ou seja, "a existência de duas vias democratizantes que tencionam direcionamentos possíveis no âmbito da sociedade civil - a determinante institucional, desvinculada de ações políticas cotidianas que a legitimem, e seu contraponto, a que privilegia as ações diretas, sem a preocupação de estabelecer uma regulação possível para o uso de espaços e meios - acabam enfraquecendo a radicalidade de um necessário movimento pela democratização da comunicação, capaz de afirmá-la como direito humano". ${ }^{57}$

\section{8- Meios de comunicação}

Localizando-se no centro das batalhas de idéias que permeiam o interior de nossa sociedade pela sua direção ideológica, cultural e moral, os meios de comunicação se caracterizam pelo papel estratégico desempenhado nas disputas de poder. Entretanto, ao fazer essa reflexão, devemos levar em conta os interesses diversos que fazem parte dessa arena de disputas, o que implica, para os meios, em uma busca de algum nível de equilíbrio entre estes interesses, mas sem esquecer os fatores mercadológicos e de audiência que norteiam suas atividades e aos quais buscarão estar sempre ancorados.

Quando silencia ou dá visibilidade a determinados assuntos, se colocando como fonte de interpretação da realidade, a mídia se consolida como ator preponderante na produção de símbolos e imaginários necessários à manutenção da cultura hegemônica. De acordo com Liráucio Girardi (2007), “trata-se de uma capacidade de criar quadros de representação (frames), de colocar a força da doxa, do senso comum, ao lado de determinados agentes e seus interesses". Para Marx (1997), o poder e a importância dos meios de comunicação se devem ao fato de que "transportam signos; garantem a circulação veloz de informações; movem as idéias; viajam pelos cenários onde as práticas sociais se fazem; recolhem, produzem e distribuem conhecimento e ideologia". Em seu artigo "O príncipe

\footnotetext{
${ }^{57}$ CABRAL FILHO, op. cit. p. 245.
} 
eletrônico", Octávio Ianni (2003) recorreu à clássica metáfora de Maquiavel para afirmar que neste momento histórico, o príncipe são as poderosas instituições de comunicação, imprensa, rádio e televisão.

Gramsci considerava os meios de comunicação como a parte mais dinâmica da superestrutura ideológica das classes dominantes, ao cumprir a função de organizar e difundir determinados tipos de cultura, influindo no modo como a opinião pública assimila os acontecimentos. Ou seja, para ele os jornais cumpriam, além da função de informar, a função de direção política geral. Em seu artigo "Os jornais e o operário" (apud Borges, 2009), Gramsci alertava para o fato de que nos jornais burgueses o operário nunca tem razão, pois esses jornais apresentam os fatos, por mais simples que sejam, de uma maneira que favoreça à classe burguesa. E quanto à sua forma ampla, em que aliam os interesses ideológicos com os econômicos, ou seja, o agrado ao gosto popular na busca do público leitor e da ampliação de sua influência, ele chama de jornalismo integral. De acordo com Denis de Moraes,

os meios de comunicação elaboram e divulgam equivalentes simbólicos de uma formação social já constituída e possuidora de significado relativamente autônomo. Na essência, o discurso midiático se propõe a determinar a interpretação dos fatos por intermédio de signos fixos e constantes que tentam proteger de contradições aquilo que esta dado e aparece como representação do real, como verdade. Tal discurso interfere preponderantemente na cartografia do mundo coletivo, propondo um conjunto de linhas argumentativas sobre a realidade, aceitas ou consideradas por amplos setores da sociedade (Moraes, 2009, p. 45)

Para nós, os meios de comunicação hoje podem ser definidos como um instrumento que detém o poder de determinar a agenda de temas a serem visualizados ou escondidos de forma a organizar a opinião pública, estando a serviço dos que detém o seu monopólio.

\section{9- TV pública}

A tipificação conceitual da comunicação pública é um dos aspectos fundamentais do debate atual sobre políticas públicas de comunicação, no Brasil e na maioria dos países latino-americanos onde a experiência desse tipo de comunicação ainda tem sido bastante incipiente. A ausência de definição conceitual contribui para a escassez de regulamentação que, onde existe, na maioria dos casos é genérica, confusa e cheia de brechas que acabam permitindo sua completa distorção, em favor dos grupos privados ou de governos de turno. 
Tal contexto só reforça o comportamento refratário frente à discussão sobre o assunto e a criação de balizas quanto ao entendimento de que a comunicação é uma área importante e sensível para a gestão pública, não podendo continuar a ser uma das menos institucionalizadas quando se objetiva garantir os direitos da população.

Um primeiro aspecto desse debate é a definição de que a comunicação pública deve estar a serviço do público. Essa afirmação se baseia no principio de que o poder público deve ser o poder do público sobre o Estado, e o seu sistema público de comunicação, ${ }^{58}$ portanto, deve ser democrático, autônomo, crítico e comprometido com os direitos dos cidadãos. Outro aspecto se refere à tipificação que, conforme os diferentes autores, pode seguir critérios diversos. Por um lado, há os que diferenciam os tipos de comunicação a partir de quatro critérios, sendo eles a comunicação pessoal; a comunicação do poder público; a comunicação empresarial; e a comunicação das organizações civis. Por outro lado, há os que a classificam em seis tipos distintos, sendo eles generalizados na expressão "mídia pública”, em que constam os modelos elitista; educativo; público não-estatal; público como alternativa à mídia comercial; culturalista; e aparelho de Estado.

Entre as referencias importantes no debate acadêmico sobre o fenômeno dos meios públicos de comunicação estão os nomes de Garnham (1990), Dahlgreen (1994), Syverstsen (2003) e Habermas (2003), este último contribuindo com o conceito de esfera pública, a partir do qual alguns autores se baseiam para formular o conceito de comunicação pública, atualmente uma questão central neste debate.

Em sua clássica obra "Mudança estrutural da esfera pública”, Habermas (2003) propõe a definição de que a esfera pública seria a discussão sobre temas de interesses comuns, com base no uso da razão e da publicidade, feita em reunião pública por entes privados. Sua condição de concretização esta na capacidade de que se realize sob a publicidade de informações necessárias aos temas, sendo o interesse geral garantido por meio de um debate racional que expresse a síntese de argumentos, ao invés do conflito entre interesses particulares. Seus atores, de acordo com Habermas, são o poder público e o setor privado, Estado e sociedade civil. Com a tarefa política de regulamentação da sociedade civil, a esfera pública abrange também o setor privado, pois esta é uma esfera pública de pessoas privadas.

\footnotetext{
${ }^{58}$ No Brasil existe a predominância da expressão "sistema público de comunicação", enquanto em outros países, mesmo que haja uma lógica de "sistema", é predominante o uso do termo "public service broadcasting" ou "public broadcasting", que tem sentido distinto.
} 
Partindo de uma crítica a esse conceito, mas ainda dentro de sua lógica, há os que propõem a definição de televisão pública como sendo um aparelho de Estado, com materialidade institucional e que oferta um serviço à população. Televisão pública "designa a produção e gestão de programações distribuídas sob diversas plataformas tecnológicas diretamente pelo Estado, sendo a expressão deste em um complexo processo que vai muito além dos programas veiculados, mas envolve desde o arcabouço jurídico-institucional que molda o aparelho, passando pela operação de sua gestão e chegando até o produto veiculado e sua repercussão junto à população". 59

A partir de uma adaptação de conceitos de sociedade civil, de Gramsci, e de aparelho de Estado, de Althusser, estudiosos caracterizam a televisão pública como instrumento que, disputando o monopólio da opinião pública e disseminando a ideologia dominante, visam construir consensos a serviço da reprodução do sistema capitalista. Para os adeptos desta concepção, este processo não ocorre de forma simples, como numa correia de transmissão althusseriana, mas é atravessado pelos embates, disputas e lutas de classe pela hegemonia, como na visão gramsciana. Para esta concepção, a questão do controle da ação desses aparelhos de Estado é o ponto essencial na definição dos resultados das suas lutas internas e na definição do aspecto democrático de um sistema de comunicação. Em nosso estudo, nos aproximaremos dessa concepção.

A principal crítica feita ao conceito de comunicação pública (além das, é claro, que surgem motivadas no preconceito que deriva da hegemonia da comunicação do tipo comercial), se sustenta na sua alegada inconsistência, posto que seria incorreta a transposição do conceito de esfera pública para dentro da organização do Estado, o que contradiz a própria noção habermasiana de esfera pública. Segundo esses críticos, a idéia de comunicação pública parte de um paradigma liberal, segundo o qual a comunicação,

para atender aos requisitos da sociedade, deve afastar-se do Estado, e não se aproximar dele para interferir em suas diretrizes e ações. Tal falácia normalmente ampara a defesa de uma pretensa independência da comunicação social financiada pelo poder público em relação os governos. Outro problema é a omissão quanto à figura do Estado, da qual o governo é apenas uma de suas organizações (Lassance, 2011, p 169).

Entre as confusões e problemas que o termo comunicação pública daria origem estariam as dificuldades para identificar claramente o emissor desta comunicação, no caso, o

\footnotetext{
${ }^{59}$ VALENTE, Jonas. Televisão pública: da esfera pública ao aparelho de estado. 2008.
} 
Estado, resultando numa simulação ou dissimulação que escamoteia as fontes da mensagem. Ao não identificar claramente o emissor da mensagem, desrespeita um dos princípios da comunicação, que é a revelação da fonte. Quanto à inconsistência, o uso do termo esfera pública se refere mais apropriadamente à comunicação feita em público e em espaços públicos. Já que toda comunicação, a rigor, é pública, o uso do termo é considerado redundante. O nome proposto, então, seria o de comunicação do poder público. ${ }^{60}$

Esta concepção, para a qual a falta de comunicação pública gera o comportamento comum que atribui aos especialistas a função de tratar de assuntos públicos, atribui ao poder público as funções de comunicar a decisão tomada e esclarecer sua motivações; cuidar para que a mensagem transmitida seja fiel à decisão oficial, fornecendo ao cidadão a fonte oficial da decisão; garantir o caráter universal da informação; e esmiuçar o caráter contraditório das decisões.

Finalizando, caberia descrever e identificar alguns dos diversos argumentos sobre os tipos de comunicação, conforme encontramos em publicações do IPEA (Instituto de Pesquisa Econômica Aplicada) e do INTERVOZES (Coletivo Brasil de Comunicação Social). Nos estudos do IPEA encontramos uma classificação da comunicação do poder público em que se usa como critério o emissor e, entre elas, nos interessam três tipos. O primeiro deles, definido como comunicação do poder público, é a comunicação dos órgãos da administração pública, sob as mais diferentes formas, o que inclui desde pronunciamentos e publicações de diários oficiais até notícias e publicidade, veiculados em seus próprios meios ou em veículos privados de comunicação. Um segundo tipo é a comunicação empresarial, que tem a informação e o entretenimento como negócio. Por último, a comunicação de organizações civis, em que se inclui a igreja, sindicatos, partidos, etc.

\footnotetext{
${ }^{60}$ Esse pensamento se aproxima da teoria do Estado na perspectiva institucionalista, que vê como processo político central o conflito organizacional. Esta é a matriz do neo-institucionalismo, corrente que define os órgãos burocráticos e as instituições como sendo os agentes básicos do Estado, e este é definido como uma organização política de natureza autônoma com a função de auto-reprodução e expansão. Tendo como base o pensamento de Weber, Polanyi e Tocqueville, esta matriz teórica define que o eixo analítico central nas explicações das políticas governamentais é o próprio Estado. O neo-institucionalismo, como visão atualmente predominante nas ciências políticas, prevê uma volta ao Estado como um ator independente, ou seja, uma variável autônoma capaz de explicar os fenômenos sociais e políticos e que age dentro de uma lógica própria para reforçar sua autoridade e controle sobre a sociedade, afetando-a através de suas intervenções ou não intervenções (Skocpol, 1985). Entretanto, existem ao menos três vertentes do pensamento neoinstitucionalista, de acordo com Hall e Taylor (2003). São eles o neo-institucionalismo histórico, o neoinstitucionalismo da escolha racional e o neo-institucionalismo sociológico.
} 
Nos estudos do INTERVOZES encontramos a tipificação que mais se aproxima dos que trabalham com a definição de comunicação pública. São esses tipos de comunicação que detalharemos a seguir.

A maioria dos sistemas públicos europeus foi construída com base na teoria elitista da comunicação, segundo a qual os meios são instrumentos de difusão do conhecimento e da razão iluminista, devendo veicular "o melhor de tudo", e contribuindo para reduzir o abismo que separa a riqueza cultural produzida pelo homem e a população. De acordo com Leal Filho (1997, p. 18), tratava-se de se colocar no mesmo âmbito das universidades, bibliotecas e museus, distante da esfera dos negócios e da política, mas associado à disseminação da riqueza lingüística, estética e ética dos povos e nações.

Para essa concepção, relevante é a alta cultura e os padrões morais da elite, para quem apenas ela detém condições de visualizar o que a população necessita. ${ }^{61}$ Nas palavras de Reith, em seu broadcasting over Britain, ${ }^{62}$ "é normalmente indicado a nós que estamos aparentemente direcionando ao público o que pensamos que ele precisa, e não o que ele quer, mas poucos sabem o que querem, e menos ainda sabem aquilo de que precisam”. Dentro desse propósito, a televisão deveria se pautava em informar, divertir e educar, com ênfase no último propósito, pelo seu caráter diretamente formativo.

Outra teoria também focada na idéia de que a TV pública tem o papel de difundir conteúdo para população é a que se denomina educativa. Embora muito similar à elitista, seu diferencial esta na ênfase com a qual vêem a mídia como instrumento de ampliação da formação da população, tendo se vinculado fortemente à políticas educacionais, substituindo salas de aula nos lugares que apresentam déficit, ou mesmo como atividade complementar à desenvolvida em sala de aula, principalmente aportando conteúdos adicionais com o objetivo de aperfeiçoar os alunos e até mesmo os professores. Esse tipo de conceito de televisão ganhou amplo espaço em países da América Latina que experimentaram um processo de

\footnotetext{
${ }^{61}$ Essa visão tem raiz na teoria do Estado das Elites, que tem como pressuposto a idéia de que a função do Estado é a reprodução do poder das elites. A base de seu pensamento teórico esta nos escritos de Vilfredo Pareto, Gaetano Mosca, Robert Michels e Charles Wright Mills, sendo este último o responsável por sistematizações feitas a partir de estudos da sociedade americana. De acordo com esta teoria, o processo político central que ocorre na sociedade é o conflito intra-elite, sendo esta o agente societal básico. A partir de explicações sociológicas, define que a elite é quem domina o Estado e possui os atributos que não se resumem ao capital, mas incluem também o repertório cultural e relações sociais e pessoais. Para essa matriz teórica, o Estado é uma casca oca a ser ocupada pelas elites, pois as massas não têm capacidade para governar. Para Schumpeter (1984), a democracia direta não é possível porque nem todos na sociedade estão no mesmo estágio de desenvolvimento cultural.

${ }^{62}$ Encontra-se em:
} 
industrialização e urbanização em que a necessidade de uma mão-de-obra mais qualificada exigia respostas do setor educacional no sentido de atender a essas demandas. $\mathrm{O}$ fundamento apresentado para envolver os meios de comunicação nesse processo educacional partia da idéia de esses meios possuíam um potencial capaz de massificar a educação com mais facilidade, principalmente junto aos segmentos mais distantes dos bancos escolares. Em alguns países, a "teleeducação" foi apresentada como uma condição para se atingir o desenvolvimento econômico e social.

No entanto, o documento de fundação da TV Educativa do Brasil, assim como o documento basilar da radiodifusão pública dos Estados Unidos, ${ }^{63}$ apesar de fazerem apologias ao potencial papel pedagógico dessas emissoras, ressalta seu papel complementar aos bancos escolares, ou distingue a televisão educativa da televisão pública.

O terceiro tipo de televisão é apresentado como sendo uma alternativa ao modelo comercial, que surge a partir da rejeição das experiências de televisão educativa, quando a Comissão Carnegie apresentou um novo projeto de TV pública, defendendo que "este deveria pautar-se pelo atendimento de todas aquelas demandas informativas não contempladas pelos veículos comerciais, constituindo alternativa a estes (Valente, 2009, p. 32). Ainda segundo Valente, "Esta ai a abordagem presente na gênese do Public Broadcasting Service (PBS) dos Estados Unidos, bem como na recente criação da Empresa Brasil de Comunicação (EBC) em nosso país”. A grande diferença em relação ao modelo comercial é a postura em relação ao telespectador pois, diferentemente do modelo comercial, que foca no publico médio visando uma audiência massiva, o modelo alternativo prioriza a multiplicidade de públicos e aqueles segmentos deixados de fora da mídia comercial.

Seus defensores alegam que a TV pública não deve produzir entretenimento, mas focar naqueles conteúdos que não têm apelo comercial e, segundo Bucci, "diferenciar-se, recusando-se a competir no mercado e buscando dar visibilidade às expressões francamente minoritárias da cultura e do debate público, que não têm aptidão para se tornar 'campeãs de audiência' e não têm vez nas comerciais". ${ }^{64}$

Essa proposta se afirmação pela negativa refletindo o peso hegemônico do meio comercial e a dificuldade que isso ocasiona para a constituição de meios públicos. Numa outra

\footnotetext{
${ }^{63}$ Trata-se do relatório da Comissão Carnegie de TV Educativa, intitulado "Televisão educativa: uma proposta de ação". Apud: VALENTE, op. cit. p 32.

${ }^{64}$ Apud Valente, op. cit. p. 34.
} 
perspectiva, embora dentro da mesma ótica, o setor de radiodifusão da Unesco ${ }^{65}$ afirma a característica da distintividade como central em um modelo alternativo ao comercial, indicando não se tratar de produzir os tipos de programas desprezados pelos meios comerciais, mas trata-se de fazer de forma diferente do modo comercial.

Um quarto tipo de modelo se afirma por não ser estatal. O distanciamento em relação ao mercado se alia à independência do Estado, sendo feita para o público e por isso se proteger de qualquer influencia, seja do capital, seja dos partidos e políticos. ${ }^{66}$ Tendo como princípio básico o propósito de ser um serviço público, a busca pelo distanciamento em relação ao mercado e ao Estado é colocada como condição para que se produzam conteúdos imparciais e críticos. Esta concepção é a que mais se referencia no conceito habermasiano de "esfera pública", conforme discutimos anteriormente. Dentro dessa ótica, seus defensores afirmam que todos os meios de comunicação atendem ao propósito da visibilidade pública, mas somente a mídia pública pode atender ao preceito do debate público, sendo, inclusive, um espaço privilegiado para tal. De acordo com Leal Filho, o que define a possibilidade de que exista um modelo como esse, que é o mais praticado na Europa, é a garantia de que o controle e o financiamento não dependam do Estado nem do mercado. Segundo ele, "criam-se conselhos gerais autônomos, formados por representantes da sociedade, que detêm a última palavra na administração de emissoras onde a participação financeira do Estado é pequena ou simplesmente inexiste - como é o caso da BBC de Londres". ${ }^{67}$ Além dos colegiados de gestão, onde participam diversos setores da sociedade, inclusive o governo, embora de forma minoritária, é necessária uma forma de financiamento que não dependa da publicidade nem de receitas públicas.

A proposta do modelo de comunicação do tipo culturalista foi elaborada no bojo das políticas neoliberais e do fenômeno da "globalização", quando alguns teóricos diagnosticavam a existência de uma crise do Estado nacional e da noção de público, que agora estariam dando vez às comunidades de interesse voltadas para a constituição de identidades,

\footnotetext{
65 Idem.

${ }^{66}$ A independência e o referencial no serviço público são apontados pela Unesco em seu documento "Public Broadcasting: How? Why?" como fundamentais para a caracterização da mídia pública: "nem controlada pelo mercado ou pelo Estado, a razão de ser da radiodifusão pública é o serviço público. Essa é a organização da radiodifusão pública; ela fala a todos como cidadãos. Radiodifusores públicos encorajam o acesso e a participação na vida pública. Eles desenvolvem o conhecimento, ampliam horizontes e permitem às pessoas entender melhor elas próprias por meio de um melhor entendimento do mundo e dos outros. Radiodifusão pública é definida como um local de encontro onde todos os cidadãos são bem-vindos e considerados iguais". Apud: VALENTE, op. cit. P. 36.

${ }^{67}$ LEAL FILHO, Laurindo. A melhor TV do mundo: o modelo britânico de televisão. São Paulo: Summus, 1997, p. 79.
} 
agora não mais definidas na esfera da produção e nas classes sociais, mas na orientação sexual, no gênero, na cor, etnia ou em interesses diversos. As novas tecnologias forma apontadas como sintoma de que grupos distintos e locais estariam tendo acesso à produção cultural, dando voz à diversidade.

Com base nesse diagnóstico, estudiosos como Martin-Barbero, Canclini, Orozco e Beltrán apontaram para a necessidade de uma definição de TV pública autônoma e compromissada com o cidadão e com a diversidade cultural. Com ênfase no aspecto cultural, este conceito de comunicação tem como meta a manutenção de produção cultural própria, o interesse pela vida urbana, o papel de alfabetizador de novas linguagens, a interpelação dos telespectadores e uma produção profissional e inovadora.

Um último conceito é o que define a mídia pública como aparelho de Estado. Partindo de elementos da concepção marxista de Estado, que o classifica como sendo de classe, esta definição de mídia pública mais se assemelha a uma radiografia e avaliação do sistema do que uma proposição ou programa. Nesse sentido, os meios de comunicação são vistos como aparelhos estatais com a função de garantir a coesão social, reforçar os interesses o capital e informar ao público de forma a reforçar as metas anteriores garantindo as formas de consenso necessárias. Dentro da proposição de Poulantzas ${ }^{68}$ de autonomia relativa do Estado, os meios de comunicação são vistos com a função de garantir os interesses gerais do Estado. Diante da impossibilidade de existir uma instituição pública fora do Estado, seria impossível existir uma mídia pública e outra estatal. Mas isso não impediria que existisse uma estrutura mais democraticamente controlada pela esfera pública e outra mais centralizada na estrutura governamental.

\footnotetext{
${ }^{68}$ Poulantzas procurou desenvolver o que talvez seja considerado o mais complexo tratado geral de teoria política marxista, tentando compreender as formas específicas de funcionamento interno do aparelho de Estado capitalista e da prática de seus agentes utilizando o conceito de burocratismo. Ele observa a existência de uma autonomia relativa real do aparelho estatal, tanto pelo burocratismo quanto pelo fato do Estado não estar diretamente relacionado aos interesses econômicos das classes dominantes, mas sim aos seus interesses políticos, que no capitalismo constituem-se como a preservação da exploração do trabalho assalariado e da dominação de classe. É importante lembrar que essa expressão "autonomia relativa do Estado" adquire diversos sentidos ao longo de sua obra. Cf. POULANTZAS, N. Poder político e classes sociais. São Paulo: Martins Fontes, 1986.
} 
CAPÍTULO II: Contextualização 


\section{Preâmbulo: a formação dos monopólios}

Nesta pesquisa decidimos trabalhar com um recorte histórico que vai dos anos 1960 aos dias atuais e para melhor contextualizá-lo propomos fazer neste capítulo uma divisão em três etapas ou fases como forma de facilitar a nossa exposição. De acordo com Josep Gifreu, o processo de discussão e construção de uma concepção de comunicação como direito é marcado por três etapas, sendo a primeira delas o período que vai de 1945 a 1970, marcada pela hegemonia norte americana, se expressando na doutrina da livre circulação de informação. Os anos entre 1970 e 1980 seriam marcados pelo confronto aberto de concepções, sendo esta segunda fase seguida pelo que este autor chama de etapa pósMcBride. Aqui em neste capítulo delimitaremos a primeira fase entre o período que abrange as décadas de 60 e 70, caracterizadas pelo momento inicial de construção das redes de televisão, pela formação dos monopólios e associação entre oligarquias locais e o capital estrangeiro, quando também ocorrem diversos golpes militares na região. A segunda fase abrange as décadas de 80 e 90, que distinguimos aqui como de surgimento do debate sobre circulação de informação, em que a UNESCO assume papel central. Esta fase tem o desfecho na consolidação da hegemonia do pensamento neoliberal, nas privatizações e desregulamentações do setor público. A terceira fase é o século XXI, caracterizada pela reação e vitória de propostas políticas anti-neoliberais em diversos países do continente e também por uma série de novas iniciativas em políticas públicas na área de comunicação. Naturalmente, estas fases se entrelaçam e até se estendem a períodos anteriores e posteriores e o recorte serve apenas para orientar nossa tentativa de melhor explicar o processo histórico de constituição e de consolidação da TV na região, estabelecendo um parâmetro para nosso debate.

Os meios de comunicação de massa na América Latina se constituíram, na maioria dos casos, graças ao papel do Estado, que atuou com garantias e incentivos diversos para estimular aquela então novidade apenas potencialmente promissora. No entanto, por se tratar de uma região ainda pouco industrializada, de economias predominantemente primárioexportadoras, o surgimento da televisão não catalisou, de imediato, investimentos de longo prazo da parte do empresariado local, pois se tratava de uma atividade arriscada já que aquela invenção ainda era apenas uma promessa de sucesso. Os incentivos oficiais beneficiaram grupos empresariais que se articulavam com os interesses hegemônicos no Estado, mas os altos custos dos equipamentos, aliado aos proibitivos preços dos receptores contribuíam para 
que persistisse grande descrédito nesse novo meio de comunicação, inclusive por parte do setor publicitário.

A situação predominantemente agrária dos países latino americanos foi sendo suplantada no mesmo processo em que a televisão superou sua característica elitizada, passando a ser um veículo de comunicação de massa. Países como Brasil e México passam de economias agrárias para sociedades industriais urbanizadas, marcados pelo amplo processo de migração interna de populações do campo para a cidade. De acordo com Gilberto Maringoni, é "possível traçar uma relação direta da difusão dos meios de comunicação com o processo de urbanização no continente. No início do século XX, em que pesem as diferenças regionais, apenas um em cada quatro latino-americanos vivia em cidades de mais e dois mil habitantes. Cem anos depois, $75 \%$ dos habitantes do continente estavam em meios urbanos". ${ }^{6}$

América Latina: porcentagem de população urbana (1950-1990)
\begin{tabular}{|l|l|l|l|l|l|}
\hline PAíS & $\mathbf{1 9 5 0}$ & $\mathbf{1 9 6 0}$ & $\mathbf{1 9 7 0}$ & $\mathbf{1 9 8 0}$ & $\mathbf{1 9 9 0}$ \\
\hline Argentina & 62,5 & 73,8 & 79,0 & 83,0 & 87,3 \\
\hline Brasil & 36,5 & 43,0 & 55,9 & 67,6 & 78,4 \\
\hline Chile & 60,7 & 68,2 & 75,1 & 82,2 & 83,5 \\
\hline Colômbia & 42,7 & 52,1 & 59,1 & 67,2 & 71,0 \\
\hline México & 42,6 & 50,7 & 58,7 & 66,3 & 71,3 \\
\hline Venezuela & 53,7 & 67,4 & 77,2 & 84,0 & 84,4 \\
\hline
\end{tabular}
Fonte: MARINGONI (2006)

Um razão a que pode ser atribuída a atuação estatal no setor de comunicação televisivo são as políticas nacional-desenvolvimentistas ${ }^{70}$ que norteavam um conjunto de países da região naquele período, momento em que esses meios apareciam como sinônimo da modernidade galgada em suas estratégias e planos econômicos. O processo de urbanização, integração e industrialização, acelerados por aquelas políticas, contou com a televisão como agente organizador coletivo, difundindo através de seus telejornais e programação em geral

\footnotetext{
${ }^{69}$ MARINGONI, Gilberto. Mídia. IN: Enciclopédia contemporânea da América Latina e do Caribe. São Paulo, Boitempo, 2006, p. 781.

${ }^{70} \mathrm{O}$ nacional-desenvolvimentismo se caracteriza pela forte presença do Estado na elaboração de políticas econômicas, substituição de importações, o planejamento, o investimento em setores estratégicos como Petrobrás e Eletrobrás, do fortalecimento de uma ideologia urbano-industrial, além de uma visão da educação como instrumento de desenvolvimento social. Nesse período, que vai de a1947 até 1964, surge a CEPAL, o ISEB e é promulgada a LDB. Ver: PREBISCH, 1964 e IANNI, 1975.
} 
um padrão de vida urbano, fincado em hábitos de consumo de classe média, restritos ainda a uma minoria.

Dessa forma, foi através da ação estatal que foram estabelecidos os critérios para a exploração particular das concessões públicas, assim como para o estabelecimento de leis e normas regulamentando o seu uso. Uma das características dessas leis era o veto à que estrangeiros pudessem ser proprietários de TV, o que aconteceu em países como o Brasil, Argentina, México, Chile e Colômbia. No entanto, a enorme carência de capital necessário para nesse novo negócio e os insuficientes investimentos estatais contribuiu para que as empresas estrangeiras, notadamente as americanas, conseguissem burlar as leis em diversos países, se associando com empresários locais. É na década de 60 que as redes CBS (Columbia Broadcasting System), ABC (American Broadcasting Company), NBC (National Broadcasting Company), e Time-Life Broadcast Station entram na região munidos de capital para investimento, uma extensa programação para ocupar as redes, além de diversos produtos industriais e assistência técnica.

O resultado disso foi que, apesar da ocorrência de políticas públicas de comunicação em diversos países, a Televisão Pública na América Latina em seu momento inicial nunca conseguiu ocupar um espaço relevante na disputa pela hegemonia na produção do imaginário social. Seu espectro reduzido, suas limitações e deficiências puseram limites à possibilidade de que pudessem dar respostas a uma possível democratização da comunicação no continente. A ocupação do espaço público radioelétrico sul americano durante aquele primeiro momento foi marcadamente hegemonizada pelo modelo comercial de televisão.

Mas essa constatação não pode ser feita sem levar também em consideração o contexto de disputas geopolíticas que se acirravam no planeta do pós-Segunda Guerra, para as quais concorriam não somente os interesses expansionistas dos monopólios norte-americanos, a exemplo da ABC, a NBS, a CBS ou a Time-Life, como também a política externa dos Estados Unidos, ciosos por manter seu domínio econômico, político e cultural sobre a América Latina. De acordo com Daniel Herz, o próprio desenvolvimento dos meios de comunicação de massa atesta a importância das tecnologias de comunicação no processo de evolução das relações capitalistas mundiais, quando a comunicação de massa é encarada como decisiva na “inversão da conquista pela agressão armada por uma estratégia de domínio pela 'base filosófica' e pelo 'colonialismo cultural'” (HERZ, 1987, p. 84). Como parte do processo de disputa pela hegemonia na Segunda Guerra, às operações culturais e frentes ideológicas, associados ao assistencialismo dirigidos aos países subdesenvolvidos, 
foi acoplada a difusão de todo o aparato tecnológico de imprensa, cinema, indústria fonográfica e das agências de publicidade. As empresas estrangeiras, notadamente as norte-americanas, passaram a dominar a economia e o mercado publicitário, consistindo praticamente no único sistema de financiamento das empresas jornalísticas, editoras e emissoras de rádio. ${ }^{71}$

Nessa mesma linha, Herbert Schiller afirma que naquela conjuntura a dominação imperial passou a ser vista como "uma idéia inconveniente e incômoda para a maioria dos americanos que, de há muito, se julgam, aliás, de maneira justificável, descendentes da primeira insurreição anti-colonial". ${ }^{72}$ Dentro dessa lógica, destaca-se a atuação de Henry Luce, diretor da Time-Life, que conclamava em editoriais de suas publicações a que os Estados Unidos ocupassem o lugar de centro gerador de idéias pelo mundo, sendo ele o primeiro a perceber que "a fusão da força econômica com o controle da informação - a ou a apresentação da própria imagem (image-making) - e mais a formação da opinião pública, ou não importa que nome lhe dêem, é a nova quintessência do poder institucional e nacional". ${ }^{73}$

É evidente que nunca se cogitou a completa substituição do convencional método militar de travar esses combates de dominação de mercados e de intervenção, o qual não seria deixado de lado, mas tratava-se de lançar mão de formas mais profundas e amplas, que o desenvolvimento alcançado nas tecnologias de comunicação poderia proporcionar. ${ }^{74}$ Herbert Schiller lembra um informe do comitê do Congresso Americano sobre a Guerra Fria que vale a pena ser citado aqui para entendermos mais sobre o peso que a comunicação adquire naquele momento:

"Durante muchos años el poder militar y el poder económico, empleados por separado o en conjunto, han servido de pilares de la diplomacia. Todavía en la actualidad realizan esta función, pero el aumento reciente de la influencia de las masas del pueblo sobre los gobiernos, unido a una mayor toma de consciencia, por parte de los dirigentes, de las aspiraciones del pueblo, ha creado una nueva dimensión para el funcionamiento de la política exterior. Ciertos objetivos de política exterior pueden proseguirse mejor por medio del trato directo con el pueblo del país extranjero que con sus gobiernos. Gracias al uso de los instrumentos modernos de comunicación, es posible

\footnotetext{
${ }^{71}$ HERZ, Daniel. A história secreta da Rede Globo. Porto Alegre, Tchê, p. 80.

${ }_{72}^{72}$ SCHILLER, Herbert. O império norte americano das comunicações. Rio de Janeiro, Editora Vozes, 1976, p. 12.

${ }^{73}$ Idem. p. 11.

${ }^{74}$ Importante resgatar a tentativa de Charles Frankel, da Universidade de Columbia e Ministro-Adjunto da Educação e Cultura, de dar uma base filosófica ao papel estratégico desempenhado pelas comunicações na política externa americana. Frankel definia a história do intercâmbio cultural entre países e povos em três estágios. No primeiro e mais longo, o intercâmbio cultural era um simples subproduto do contato (geralmente, repelido) entre grupos diferentes. No segundo estágio uma cultura prevalecia sobre outras, de forma deliberada, motivo e conseqüência de guerras e comércio. No atual e terceiro estágio, qualitativamente diferente dos outros, ocorreria um volume e intensidade de intercâmbio cultural, com fluxo de comunicação em duas vias entre ricos e pobres, aliada ao incremento das relações sociais proporcionada pelos avanços nas ciências e comunicações. Idem, p. 25.
} 
hoy en día llegar hasta sectores extensos o bien influyentes de las poblaciones nacionales, para informarles, influir en sus actitudes y, a veces, quizás incluso impulsarles a tomar un curso de acción determinado. Estos grupos, a su vez, pueden llegar a ejercer una presión notable, y hasta decisiva, sobre sus gobiernos.",75

$\mathrm{O}$ apelo direto às massas, uma prática leninista utilizada pelos bolcheviques que fizeram Revolução Russa em $1917,{ }^{76}$ passou, então, a fazer parte da estratégia de política externa americana definida pelos seus ideólogos, de forma a assegurar "nas áreas penetradas, não uma submissão rancorosa, mas sim uma lealdade de braços abertos, identificando a presença americana com a liberdade - liberdade de comércio, liberdade de palavra e liberdade de empresa". ${ }^{77}$ Sob essa bandeira da liberdade, Harry Truman, o presidente que lançou duas bombas atômicas sobre um Japão rendido em agosto de 1945, inicia o processo expansão e de consolidação da hegemonia norte americana e de seus monopólios, ${ }^{78}$ tendo como base ideológica o "american way of life" e tudo o que isso implicava. Modernas técnicas de publicidade são utilizadas para estimular o consumo doentio, agora associado ao prazer. ${ }^{79}$

A bandeira da liberdade transformada em doutrina passou a ser utilizada pelos Estados Unidos como justificativa para intervir em qualquer país a fim de derrotar os comunistas, classificados agora como inimigos da liberdade. A máquina de guerra foi sendo incrementada e de 1947 a 1961 os EUA atuaram militarmente na Coréia, no Vietnã, Irã, Guatemala, Grécia, Líbano, República Dominicana, tentaram invadir Cuba, criaram a "Escola das Américas", no Panamá, onde treinavam militares para ações golpistas em seus países. De acordo com Herz, os investimentos maciços do Estado norte americano na indústria bélica e aeroespacial, principalmente durante a guerra do Vietnã, possibilitou a expansão da atuação dos setores da indústria eletrônica, que trabalhava para expandir o sistema sócio econômico, espacial e ideologicamente. Ainda de acordo com ele,

\footnotetext{
${ }^{75}$ SCHILLER, Herbert. Comunicación de masas e imperialismo yanqui. Editorial Gustavo Gili, Barcelona, 1976, p. 21

${ }^{76}$ De acordo com Schiller, Lenin estimulava atingir as "massas" de outros países, tirando vantagens da insensibilidade dos meios de comunicação do estado burguês. Op. cit. p. 23.

${ }^{77}$ SCHILLER. O império Norte-Americano das Comunicações. p. 13.

${ }^{78}$ Tendo assumido a presidência após a morte de Roosevelt, de quem era o vice-presidente, Truman inicia o processo de desconstrução do New Deal e dos limites que esta política impunha aos monopólios, pondo fim à concepção rooseveltiana de cooperação e convivência pacífica e inaugurando a "Guerra-Fria", a chantagem nuclear, a política intervencionista e, internamente, a caça às 'bruxas comunistas'. Para isso, a criação da CIA (Central Intelligence Agency) em 1947 foi um marco importante, pelo papel fundamental que desempenha neste processo. Ver:

${ }^{79}$ De acordo com Eduardo Galeano, o tempo de lazer passou a ser tempo de consumo associado a cultura do descartável e do efêmero, da moda associada à necessidade de vender. "As mercadorias são fabricadas para não durar, são tão voláteis quanto o capital que as financia e o trabalho que as gera." GALEANO, Eduardo. 0 império do consumo. Carta Maior, 17.01.07.
} 
A produção da indústria eletrônica foi então voltada para a introdução de sofisticadas tecnologias de comunicação e informática nos países do terceiro mundo. Esse fluxo econômico e tecnológico, além dos interesses inéditos da indústria eletrônica, atua como apoio logístico para a instalação das transnacionais que operam em diversos setores da economia e que necessitam de instrumentos de estimulação de mercado. ${ }^{80}$

Nesses anos de "Guerra-Fria", o desenvolvimento de pesquisas em comunicação aliou o setor militar e o industrial na tarefa de propagar o ideário americano de culto à liberdade de empresa. Columbia Broadcasting System (CBS), Radio Corporation of América (RCA), National Broadcasting Corporation (NBC) e American Broadcasting Corporation $(\mathrm{ABC})$ estão entre companhias do setor de comunicação que mais atuaram fora dos Estados Unidos da América, forçando a alteração de leis nacionais para acomodar os investimentos americanos. Na década de 60 a empresa ABC estava presente na Guatemala, El Salvador, Honduras, Costa Rica, Panamá, Colômbia, Venezuela, Equador, Argentina e Chile. Ainda de acordo com Schiller, "a florescente cadeia dominante da economia e das finanças americanas utiliza os meios de comunicação para a sua penetração e entrincheiramento onde quer que já esteja instalada e para sua expansão até lugares onde espera tornar-se ativa" (SCHILLER, 1976, p. 13 e 14.).

Podemos, assim, entender a expansão da comunicação como parte importante da política externa dos Estados Unidos, em um momento decisivo para as disputas geopolíticas, salientando que o peso norte-americano nas comunicações latino-americanas é algo mais amplo e remete também à venda de equipamentos eletrônicos, assistência técnica e administrativa, além do fornecimento de programas "enlatados" para todo o continente.

Para isso os EUA viam como necessário remover o nacional-desenvolvimentismo, ou nacionalismo terceiro-mundista que imperava ao sul do continente, que defendia como remédio para a superação da pobreza a utilização de uma estratégia de industrialização voltada para dentro e não mais as exportações de produtos primários. Além disso, a nacionalização dos recursos naturais, que deveriam ser regulados pelo Estado. De acordo com Naomi Klein, naquele período

O laboratório mais avançado do desenvolvimentismo era a zona sulina da América do Sul, conhecida como Cone Sul: Chile, Argentina, Uruguai e partes do Brasil. Seu epicentro era a Comissão Econômica para a América Latina (CEPAL), órgão das Nações Unidas baseado em Santiago do Chile, e conduzido pelo economista Raúl Prebisch, de 1950 a 1963. (...) Políticos nacionalistas, como o argentino Juan Perón, colocaram suas idéias em prática como desforra - investindo dinheiro público em projetos de infra-

\footnotetext{
${ }^{80}$ HERZ (1986), p. 85.
} 
estrutura como estradas e usinas siderúrgicas, subsidiando empreendimentos locais com generosidade, a fim de construir suas novas instalações que produziriam enormes quantidades de carros e máquinas de lavar, e proibindo a entrada de importados por meio de tarifas elevadas. ${ }^{81}$

Tamanho desenvolvimento autônomo, que fortalecia os sindicatos com as novas indústrias, aumentava o poder do salário e o tamanho da classe média, exibia taxas de alfabetização de 95\%, como no Uruguai, e ofertava atendimento de saúde gratuito, colocando em xeque a hegemonia norte americana na região. "O desenvolvimentismo foi tão espantosamente bem-sucedido por um período, que o Cone Sul da América Latina se transformou num forte símbolo para países pobres de todo o mundo", afirma Klein. ${ }^{82}$

Insatisfeitos com isso estavam os grandes proprietários de terra diante da possibilidade de realização de uma reforma agrária como exigiam os trabalhadores do campo, as corporações norte-americanas e européias que tinham negócios na região e o próprio governo americano, que passou a classificar o desenvolvimentismo sul americano na esfera da Guerra Fria, alegando que "o nacionalismo do Terceiro Mundo é o primeiro passo rumo ao totalitarismo comunista e deve ser combatido pela raiz" ${ }^{83}$ Ainda de acordo com Klein, os dois maiores representantes dessa teoria eram os irmãos John e Allen Dulles, o primeiro, secretário de Estado de Eisenhower, o segundo, o diretor da recém criada CIA. ${ }^{84}$

É nesse quadro de disputas que a comunicação de massas se desenvolve na América Latina, refletindo em sua construção as contradições entre políticas nacionaldesenvolvimentistas e as pressões hegemônicas dos monopólios norte americanos, o que vai se materializar em um quadro de dependência de capital externo e na utilização do modelo comercial de televisão ancorado em modernas tecnologias de comunicação. Durante a "Conferência sobre o Desenvolvimento Latino-Americano", realizado em outubro de 1964, o dirigente do grupo Time-Life Broadcast Inc. discorreu sobre a "Expansão de programas de TV na América Latina", quando revela a estratégia das empresas americanas para a região, dentro de orientações comerciais que incluem certos manejos com as leis locais, a necessidade de existência de sócios nesses países, programação conjunta norte e latino-americana, além de um uso utilitário da programação diurna, em sua forma educativa, como remédio eficaz e popular, sobre o qual o "governo norte-americano pode e deve se interessar". 85

\footnotetext{
${ }^{81}$ KLEIN, Naomi. A doutrina do choque. A ascensão do capitalismo de desastre. Nova fronteira, Rio de Janeiro, 2008, p. 71.

82 Idem, p. 72.

83 Idem. p. 75.

84 Ibid.

${ }^{85}$ HERZ,
} 


\section{O Brasil}

No Brasil, primeiro país da América Latina a inaugurar um sistema televisivo, são conhecidos os resultados das tensões com o imperialismo decorrente do posicionamento nacionalista de Getúlio Vargas na década de 50.

É nesse período que a Central Intelligence Agency (CIA), norte-americana, começa a operar no país. E os grandes jornais, financiados pelas agencias de publicidade estrangeiras e pelas grandes empresas multinacionais, moveram violentas campanhas contra o governo, conseguindo, entre outras concessões, a demissão do ministro do Trabalho, João Goulart. Os Estados Unidos desestabilizaram a economia com uma série de medidas, entre as quais o bloqueio às exportações de café. O jornal "Última Hora", apoiado por Vargas, foi massacrado por receber financiamento de órgãos públicos, o que era comum mesmo entre os jornais que promoviam a arrasadora campanha de perseguição. Ficou comprovado que o "Estado de São Paulo", o "Globo", e o Correio da Manhã" foram remunerados pela publicidade estrangeira para moverem campanhas contra a nacionalização do petróleo, conforme investigou em 1957 uma Comissão Parlamentar de Inquérito da Câmara Federal. ${ }^{86}$

A inflexão se dá com Juscelino Kubitschek, que abandona a idéia getulista de autonomia econômica e direciona sua estratégia desenvolvimentista no sentido da internacionalização da economia, com base no capital e na tecnologia estrangeira. A televisão ocupa maior espaço nesta fase, aumentando sua fatia na captação de verbas publicitárias. De acordo com Herz, "O rádio, em 1950, captava em torno de $24 \%$ dos investimentos publicitários, caindo para 14\% em 1960. A televisão, surgida em 1950, já participava, em 1960, com 9\% de verbas publicitárias." 87

Em 1962 surge o Código Brasileiro de Telecomunicações na forma da Lei 4.117, com o objetivo de regular o setor televisivo em plena expansão. O Código definia o espaço radioeletrônico como espaço público, estabelecia o sistema de concessões por tempo determinado, renováveis periodicamente e criava o Fundo Nacional de Telecomunicações, responsável pela expansão do sistema até as áreas mais distantes e menos lucrativas para a iniciativa privada. Também estabelecia a proibição de sua posse a estrangeiros.

Outro marco importante nesse processo foi a criação em 1965, já sob a ditadura militar $^{88}$, da Empresa Brasileira de Telecomunicações (Embratel) que, com tecnologias

\footnotetext{
${ }^{86}$ HERZ, 1986, p. 81.

${ }^{87}$ Idem, p. 83.

${ }^{88} \mathrm{O}$ ciclo de ditaduras militares que ocorreu no Cone Sul do continente baseava-se na doutrina de segurança nacional e se inseria no clima de guerra fria predominante naquele mundo bipolar de então. Eram aliadas dos Estados Unidos na propaganda anticomunista, o que tornava os meios de comunicação desses países numa trincheira estratégica. Tendo iniciado em 1964, no Brasil, se estendeu à Bolívia (1964), Argentina (1966 e 1976), Chile (1973) e Uruguai (1973). Para mais, ver: SADER, 2006, p. 412.
} 
próprias, através do sistema de microondas contribuiu para que o sinal das grandes redes alcançasse público nacional. Em 1967 surge o Ministério das Comunicações estabelecendo restrições à formação de monopólios e reafirmando a proibição à participação de grupos estrangeiros no setor. Em 1970 seria alcançada a transmissão via satélite e em 1972 a transmissão colorida chegava às telas de TV no país.

Alguns estudiosos apontam esse período como o de consolidação do tipo de televisão que existe no Brasil, marcado por acontecimentos

\begin{abstract}
que tienem que ver com el próprio médio y com su contexto. Podemos indicar, entre otros, a) La promulgación del Código Brasileño de Telecomunicaciones, que vino a poner disciplina y organizar el campo de la radiodifusión, reforzando su vocación comercial y privada mediante el otorgamiento de concesiones por parte del gobierno federal; b) la aparición del aparato de video, que revolucionó el sistema de producción de programas, al permitir su grabación y abrir el camino para centralizar la producción en Rio de janeiro y en São Paulo; c) la organización de la televisión en redes todavía precarias, puesto que en 1967, el principal espacio informativo de Rio de Janeiro se seguía emitiendo en Uruguaiana, en la frontera con Argentina, con 24 horas de retraso; d) la instrumentalización de la televisión por parte de los militares, a raíz del golpe militar de 1964, dentro del marco de la doctrina de la seguridad nacional y de la guerra psicológica que los militares consideraban que se estaba produciendo; y, lo que es más importante, la consolidación de las industrias culturales del país." ${ }^{\circ 9}$
\end{abstract}

O que podemos constatar é que a radiodifusão pública, no entanto, apesar de todo o papel desempenhado pelo Estado para desenvolver o setor, surge com foco apenas no atendimento à demanda por educação, "em um país que experimentava uma industrialização acelerada, para a qual havia carência de mão-de-obra qualificada em um cenário de crescimento do contingente populacional" $" 90$. Às TVs comerciais, restaria a parte lucrativa representada na demanda por entretenimento, cultura e informação, no que se consolidaram como legítimas transmissoras desse tipo de conteúdo.

Esta divisão do bolo foi oficializada em 1967 com a criação, através do Decreto-Lei 236, das TVs Educativas e do surgimento da Fundação Centro Brasileiro de TV Educativa (FCBTVE) com o objetivo de viabilizar a produção de conteúdo educativo a serem transmitidos nas TVs públicas. É nesse processo que surgem, pela mão de governos estaduais, algumas TVs educativas, como a TV Universitária de Pernambuco e a TVE do Rio de Janeiro. Em São Paulo, o governo adquire uma falida TV Cultura do grupo Diários e Emissoras Associados, transformando-a em referência no setor.

\footnotetext{
${ }^{89}$ CAPARELLI, S e SANTOS, S. IN: OROZCO, 2002, p. 71.

${ }^{90}$ VALENTE, Jonas, 2009, p. 270.
} 
Na década seguinte o governo federal, além de produzir conteúdos através do Programa Nacional de Teleeducação (Prontel), iria centralizar as atividades da radiodifusão pública através da criação da Empresa Brasileira de Radiodifusão (Radiobrás), em 1975.

Enquanto as emissoras estatais se restringiam ao conteúdo educativo, a radiodifusão comercial e privada ocupava uma função hegemônica no espaço radioeletrônico, aproveitando-se dos investimentos do Estado, assim como burlando as leis e se associando com o capital estrangeiro. Maior exemplo disso foi o ocorrido com a Rede Globo, a então pequena emissora do empresário Roberto Marinho, que firmou acordo com o grupo americano Time-Life, de quem recebeu à época US\$ 6 milhões de dólares para construir estúdios, contratar os melhores profissionais das emissoras concorrentes, comprar equipamentos e montar uma cadeia nacional de estações de rádio e televisão em todas as principais cidades do país. Isso sem falar na oferta de conteúdos 'enlatados' que garantiriam a plena ocupação de sua grade de programação. Esse esquema entre o grupo dos Estados Unidos e a Rede Globo colaborou enormemente para desequilibrar rapidamente a concorrência e garantir a sua hegemonia no mercado televisivo nacional. Por outro lado, a ligação da empresa com o regime militar possibilitou o arquivamento da Comissão Parlamentar de Inquérito (CPI) que foi instaurada em 1965 e, após ampla investigação do caso, pediu a cassação da concessão pública por infringir a lei que proibia a ingerência estrangeira, assim como a participação de capitais forâneos no setor ${ }^{91}$.

É nesse quadro que a televisão brasileira se estabelece no centro do mercado da indústria cultural do país, com o uso de tecnologia de ponta, capital estrangeiro, concentração horizontal, vertical e cruzada e o uso de telenovelas como carro chefe da programação, fórmula que garante a consolidação do gigantesco monopólio comercial privado. As TVs públicas, por outro lado, se reduzem a focos regionais com programação limitada, portanto fora da disputa pele hegemonia na produção do imaginário social.

\section{A Venezuela}

A Venezuela também passou por uma experiência semelhante, embora trilhada por caminhos diversos, matizados em sua própria conjuntura política e econômica. Apesar de ter

\footnotetext{
${ }^{91}$ A história do acordo que envolveu a Time-Life, a Rede Globo, a ditadura militar e o governo americano é contada com riqueza de detalhes por Daniel Herz (1987). Dela faz parte a violação do artigo 160 da Constituição com a presença dos cubano-americanos Joseph Wallach e Goar Mestre, pagos pela empresa americana, na direção da Rede Globo; as ameaças da Standard Oil - Esso Brasileira de Petróleo ao presidente da ABERT, João Calmon, entre outras histórias curiosas.
} 
iniciado estatal, a televisão venezuelana rapidamente se consolidou em sua vertente comercial monopolista, associada ao capital americano, em uma situação em que a regulamentação era quase nula. Para Capriles (1991), o Estado da ditadura militar de Marcos Pérez Jiménez não assimilou as implicações sociais do fenômeno televisivo, deixando seu funcionamento a cargo de uma velha legislação de radiocomunicação de 1941. Assim é que a televisão chega pelas mãos do Estado, através da Televisora Nacional (canal 5), com transmissões regulares desde 1953, mas sem chegar a ocupar lugar de destaque.

Isso vai ficar a cargo de dois grupos privados, Venevisión, da família Cisneros, e a Radio Caracas Televisión (RCTV), da família Phelps que, associados aos mesmos grupos americanos que atuavam por todo o continente, ajudam a consolidar no país a televisão de tipo comercial e privada, reprodutora do modelo estadunidense.

Assim é que a Venevisíon surge em 1961 e ocupa espaço já associada à American Broadcasting Company (ABC) e à Pepsi-Cola Internacional, que juntas controlavam quase 80\% do capital da empresa. Robustecida pelo dinheiro americano, Venevisión expande seus tentáculos por todo o país, adquirindo e se associando com pequenas empresas regionais, o que vai possibilitar a uniformização de sua programação em cadeia nacional. É o mesmo caso da outra grande empresa que atua na Venezuela, a RCTV, que se associou à NBC americana, potencializando seu alcance nacional através das vantagens de acesso a equipamentos, assistência técnica, programação e capital. É o que Muraro (1987) explica como tendo sido o remédio encontrado para resolver as enormes carências de investimentos que o meio exigia, levando os empresários a "subordinarse a las grandes cadenas de radio y television de los Estados Unidos (la CBS, la ABC o la NBC), o otros grupos de igual origen pertencientes al sector de las comunicaciones masivas".

A consolidação da televisão como paradigma e instrumento da indústria cultural tem na publicidade uma de suas formas de sustentação e impulso, o que a fez concentrar em suas mãos mais de $60 \%$ das verbas publicitárias em seu início, sendo a maior concentração do mundo em um só meio. Isso favoreceu o desenvolvimento de agencias agências de publicidade estrangeiras e a demanda por produtos estrangeiros, monopolistas das telinhas.

E assim como ocorreu no Brasil, existiu também na Venezuela um movimento de retirada dos capitais americanos já na década de 70, quando a TV a cabo se consolidava nos Estados Unidos e os monopólios por aqui já estavam consolidados e garantiam a reprodução dos conteúdos que vinham do Norte. De acordo com Caparelli e Santos, esse foi um fenômeno que ocorreu em quase toda a televisão latinoamericana, fazendo-a entrar em uma 
nova fase de desenvolvimento e de expansão geográfica. ${ }^{92}$ Nora Maziotti cita Daniel Jones para explicar os motivos para a retirada das empresas americanas do Cone Sul, que diz que "por un lado, se debia a um cambio em La estratégia 'motivado por uma disminución importante em los benefícios de explotación de las redes hertzianas em Estados Unidos, estaban comenzando a introducirse em el negócio del vídeo doméstico y em la televisión por satélite y por cable". 93

De fato, na Venezuela, o governo do presidente democrata-cristão Rafael Caldeira emitiu um Decreto-Lei em 1974 que impunha a retirada do capital estrangeiro das empresas dos meios de comunicação, fato que ficou conhecido como "venezuelização dos capitais estrangeiros", sob o argumento de que a enorme influencia que esses meios exerciam na vida do país exigia que assumissem responsabilidade plena sobre seu papel.

Apesar disso, o Estado venezuelano sempre renunciou a "contar com uma estación televisiva que lograra la integración social necesária a um proyecto de país, en términos no solo políticos, sino fundamentalmente culturales". ${ }^{94}$ A mesma situação se repetiu ao longo da história, seja com a Televisora Nacional, de 1952, ou com a Venezolana de Televisión (VTV), de 1974, ambas empobrecidas em conteúdo, qualidade técnica, profissionais e equipamentos. Em 1998 restava na Venezuela apenas a VTV como canal estatal.

\section{A UNESCO e o debate sobre a democratização e a circulação de informação}

É no âmbito da Organização das Nações Unidas (ONU) e de seus discursos normativos fruto de debates entre representantes governamentais e não-governamentais que o tema do direito à comunicação vai ganhar força teórica e prática, sendo motivo de muitas polêmicas no cenário das relações internacionais. A UNESCO $^{95}$ foi o órgão que mais

\footnotetext{
92 CAPARELLI, S e SANTOS, S. Op. cit, p. 256.

${ }_{93}$ MAZZIOTTI, Nora. La televison em Argentina. IN: História de la televisón em América Latina.

${ }^{94}$ Idem, p. 264.

${ }^{95}$ A UNESCO foi criada com o propósito de se estabelecer uma cooperação intelectual e científica entre as nações, tendo seu projeto de criações sido submetido à Conferência Internacional de Londres em 1945, e sua Constituição entrado em vigor em novembro de 1948. No primeiro artigo de sua Convenção de fundação foram estabelecidos a contribuição para paz, e a segurança através de uma maior colaboração entre os países no que se refere à educação, ciência e cultura; e o respeito universal à justiça, a lei, aos direitos humanos e às liberdades fundamentais, reconhecidos pela Carta das Nações Unidas a todos os povos do mundo, sem distinção de raça, sexo, idioma ou religião. Como estratégia para a realização dessas finalidades, a UNESCO estaria responsável por fomentar o conhecimento e a compreensão mútua das nações, prestando seu auxílio aos organismos de informação para as massas; dar novo e vigoroso impulso a educação popular e a difusão da cultura; e ajudar com a conservação, o progresso e a difusão do saber. A sua estrutura orgânica é formada pela Conferência Geral, Conselho Executivo e Secretaria. A UNESCO é formada por representantes dos Estados-
} 
contribuiu, transformando-se no palco principal deste processo que ficou marcado pela publicação, em 1980, do livro "Um Mundo e Muitas Vozes - Comunicação e Informação na nossa Época”, conhecido como Relatório McBride. De acordo com Gifreu:

O debate internacional da comunicação é um debate essencialmente contemporâneo e substancialmente político. Forma-se com o desenvolvimento da segunda Guerra Mundial, nasce com a vitória dos Aliados e a emergência da nova potencia hegemônica que são os Estados Unidos da América, cresce ao longo do pós-guerra em meio marcado pela guerra fria e pelo processo de descolonização, e chega aos anos setenta em plena crise de puberdade e de crescimento, para culminar nos oitenta com um grau de maturidade já notável. O informe McBride, terminado e aprovado em 1980, poderia simbolizar este ponto de variação no avanço, globalização e internacionalização da discussão da comunicação e informação. E quando em 31 de dezembro de 1984 os Estados Unidos decidem concretizar a decisão de abandonar a UNESCO, parece cumprir-se este primeiro ciclo de maturidade do debate. (GIFREU, 1986, p.7)

Tendo como atribuição cuidar de questões mundiais ligadas à educação, ciência e cultura, a UNESCO se pauta no compromisso de fazer valer os direitos humanos afirmados em outros documentos da ONU, como por exemplo, os consagrados na Declaração Universal dos Direitos Humanos e consolidados nos Pactos e Convenções Internacionais. No âmbito de suas atribuições institucionais estão as questões da comunicação e da informação.

Fisher afirma que já na "Resolução 59 da Assembléia Geral de 1946 declarou-se que 'a liberdade de informação é um direito humano fundamental e é a pedra de toque de todas as liberdades às quais à ONU se consagra"” (FISHER, 1982). O Artigo XIX da Declaração Universal dos Direitos Humanos, aprovada pela Assembléia Geral em 10 de dezembro de 1948 é emblemático ao afirmar que:

Todo o indivíduo tem direito à liberdade de opinião e de expressão, o que implica o direito de não ser inquietado pelas suas opiniões e o de procurar, receber e difundir, sem consideração de fronteiras, informações e idéias por qualquer meio de expressão (Declaração Universal dos Direitos Humanos, ONU).

A história dos debates ocorridos dentro da UNESCO é fundamental para a compreensão da trajetória do conceito da comunicação como direito humano. Seu contexto se deu em um momento de disputa pela hegemonia entre capitalismo e socialismo, o que significava o confronto entre distintos modelos de vida social, cultural, de sistema político, econômico e principalmente de pensamento ideológico. Este processo forçou a emergência de

Membros e, por isso, suas resoluções são conseqüência da correlação de forças entre seus membros, o que muda de acordo com a realidade histórica. 
princípios e valores éticos baseados no respeito aos direitos humanos, quando os temas “informação e comunicação" são alçados a categoria de objetos de investigação científica nas mais variadas áreas do conhecimento. Isso se dava na medida em que novas técnicas ampliavam a capacidade dos meios de comunicação de massa que, ao potencializar a difusão de bens simbólicos com o apoio da industrialização, incrementava a cultura de massa, denominada pela teoria crítica da comunicação de indústria cultural. ${ }^{96}$

É nesse âmbito que os primeiros documentos da UNESCO dão força e ratificam o anseio pela liberdade de informação como resposta ao projeto do livre fluxo de informação, "free flow", criticado por ser, de acordo com Gifreu, uma "maneira de denominar o substrato teórico que inspirou, acompanhou e justificou a progressiva intervenção norte-americana no mundo do pós-guerra nos domínios da cultura, da informação e da propaganda."97

Inicialmente concentrando esforço no sentido de garantir a acessibilidade de tecnologias de comunicação e equipamentos de recepção aos países periféricos, a UNESCO atuou pela eliminação de obstáculos à liberdade de informação destinada às massas.

Ainda de acordo com Gifreu, inicialmente a $\mathrm{ONU}^{98}$ encarregou a UNESCO pela promoção do livre fluxo de informação, o que a levou a estudar a situação dos circuitos de comunicação no mundo e a operar no sentido de "oferecer ao sistema mundial instrumentos de conhecimento e ação nesse âmbito, perfeitamente de acordo com os interesses gerais de controle dos centros metropolitanos sobre as periferias emergentes". ${ }^{99}$ A discussão estava centrada na vinculação da comunicação com o desenvolvimento, o que coincidia com a

\footnotetext{
96 Indústria cultural (Kulturindustrie) é o termo cunhado pelos filósofos e sociólogos alemães Theodor Adorno (1903-1969) e Max Horkheimer (1895-1973) para nomear a situação da cultura industrializada na sociedade capitalista industrial. Ao tratar a obra de arte como objeto de mercadoria, a sociedade capitalista neutraliza o valor crítico da arte erudita ou popular. Produtos idealizados e adaptados ao consumo de massa contribuem para a reprodução ideológica do sistema, impondo comportamentos e incentivando a reificação. A comunicação de massa esta diretamente ligada à indústria cultural, pois ambas atingem grande número de pessoas e têm capacidade de transmitir conhecimento ou de alienar. Ver: ADORNO, Theodor e HORKHEIMER, Max. A indústria cultural - o iluminismo como mistificação das massas. In: Indústria cultural e sociedade. São Paulo: Paz e Terra, 2002

${ }^{97}$ GIFREU, 1986, p.26-27.

${ }^{98}$ Não poderíamos olhar para a ONU deste período fora da dinâmica da Guerra Fria e das disputas geopolíticas que se refletiam internamente em sua atuação. A desconstrução do New Deal e da política de cooperação internacional anteriormente conduzida por Roosevelt nas Nações Unidas, o que já citamos em nota anterior, tem no caso Hiss uma situação emblemática. Ao ser acusado em 1948 de ser um espião soviético, Alger Hiss, Secretário-Geral da Conferência de fundação da ONU e colaborador do presidente Roosevelt, viu sua situação simbolizar o processo de caça às bruxas que encobria as disputas hegemônicas em que os monopólios retomaram o poder nos EUA e a direção que este país tentava dar à ONU. Em parte, isso pode auxiliar a explicar as posições iniciais da UNESCO, limitadas ao endosso do livre fluxo de informação, como queria os EUA. Mais informações em: LINDER, Doug. The Trials of Alger Hiss: A Commentary. 2003. http://law2.umkc.edu/faculty/projects/ftrials/hiss/hissaccount.html ${ }^{99}$ GIFREU, 1986, p. 34.
} 
expansão da televisão, beneficiado pelo uso de novas descobertas tecnológicas, a exemplo do satélite. Atribuía-se aos meios de comunicação um papel fundamental para "acelerar o desenvolvimento, fazendo deles meios também, e principalmente, de educação, inclusive de educação à distância" (RAMOS, 2000).

Sem externar uma preocupação clara com a realidade de cada país e com os seus processos singulares, a UNESCO em sua época inicial ainda concebe o alcance do desenvolvimento como uma passagem linear da sociedade tradicional, cheia de defeitos e carências, para a sociedade moderna, a única capaz de garantir a revolução das esperanças crescentes, no dizer de Mattelart (2005, p. 49).

Dessa forma, reforçava a idéia simplificada de que era possível alcançar a modernização por meio da aquisição de tecnologias da comunicação e dos avanços industriais, o que a levou a desenvolver estudos que comprovassem os benefícios do livre fluxo de informação para o desenvolvimento dos países periféricos. Em uma resolução de 1950, no tema "Comunicação de massas", há uma conclamação para que seus membros contribuam para a eliminação de barreiras ao livre fluxo de informação, posto ser atribuída à “informação" a capacidade de acelerar os avanços do entendimento internacional. Nesse sentido, afirma que a UNESCO reconhece a imensa importância dos meios de comunicação de massas e que em um mundo livre o direito à informação se coloca como prolongação do direito à educação. ${ }^{100}$ Tal era a força que possui naquele momento essa idéia de livre fluxo de informação como forma de resolver as desigualdades entre as nações em desenvolvimento que se chegou a propor que os países deveriam observar padrões mínimos de meios de comunicação a serviço da população. Esse viés do debate só perderá força com as mudanças conjunturais, quando se começou a perceber que o conteúdo dos sistemas de comunicação e o direito do povo de usá-lo era algo muito mais importante para debater (FISHER, 1982).

É somente a partir da ampliação da ONU com a entrada de diversos países recémdescolonizados no pós-Segunda Guerra, particularmente os pertencentes ao Movimento dos Países Não-Alinhados (MNA) ${ }^{101}$, que a UNESCO irá repercutir em suas conferências e

\footnotetext{
${ }^{100}$ Records Of The General Conference Of The United Nations Educational, Scientific And Cultural Organization, Florence, 1950. IN: http://unesdoc.unesco.org/images/0011/001145/114589e.pdf (acessado em 18.12.11). ${ }^{101}$ O MNA surge a partir da Conferência dos países afro-asiáticos de Bandung realizada em 1955, no contexto da Guerra Fria, com o objetivo unificar países ex-colônias em torno de uma posição independente dos dois blocos compostos pelos EUA e URSS e tendo como prioridade a pauta das lutas nacionais pela independência, pelo desenvolvimento econômico, fim do colonialismo, do imperialismo e do neo-colonialismo. Da América Latina, Cuba foi o único país participante de sua fundação. O MNA Consolidou-se como um instrumento de coordenação política entre países que passaram por um processo de descolonização, no entendimento de que a Guerra Fria não fazia sentido para os países que lutavam para se desenvolver economicamente, melhorar as
} 
resoluções o debate sobre o direito à comunicação, invertendo seus objetivos ao dar prioridade a questões levantadas pelo MNA.

Ao trazer para dentro dos debates da UNESCO a discussão sobre o desenvolvimento e a situação dos países do Terceiro Mundo, o MNA contribuiu para estabelecer uma nova correlação de forças na elaboração de estratégias econômicas, contribuindo de forma decisiva no debate sobre circulação de informação ao se contrapor à doutrina do livre fluxo. Com isso, o que se percebe ao longo dos debates e resoluções feitas a partir da década de 60 é que há um processo de complexificação nas abordagens do tema comunicação e um aumento da compreensão de que os problemas da comunicação e da informação não podem ser separados dos problemas econômicos, sociais e culturais.

Um exemplo dessa nova situação ocorre em 1965 quando, ao avaliar o impacto que seria causado pela nova tecnologia dos satélites de comunicação sobre os países em desenvolvimento, a Conferência da UNESCO se deparou com o debate sobre a necessidade de se estabelecer algum tipo de proteção soberana sobre os tipos de programas a serem exibidos, conclamando que a discussão avançasse além das abordagens sobre as técnicas de comunicação, para preocupar-se também com o conteúdo do que é transmitido, com o que se poderia chamar de mecânica do nivelamento cultural. Nesta Conferência, realizada em Paris, o Diretor-Geral da Radio All-India declarou que

O fato de um mundo inteiro abater-se livremente sobre povos de boafé e comparativamente menos sofisticados pode ter conseqüências extremas. A não ser que essas forças sejam controladas internacionalmente, será difícil dizer se as vantagens pesarão mais que as desvantagens... Em última análise, a liberdade pode ter de ser interpretada, não como uma simples remoção da censura, mas como uma criação de oportunidades". ${ }^{102}$

A introdução da tecnologia do satélite ${ }^{103}$ foi um acontecimento fundamental que contribuiu para a emergência dessas preocupações que, superando o debate sobre a questão do

condições de saúde de sua população, garantir a produção de alimentos e impedir as tentativas de neocolonialismo, assim como derrotar o racismo.

102 Reunião de peritos em utilização das comunicações espaciais pelos meios de comunicação coletiva. UNESCO, Paris, 6 a 10 de dezembro de 1965, Relatório. IN: Schiller, 1976, p. 141.

${ }^{103}$ Os EUA buscaram extrair o máximo de proveito de suas vantagens tecnológicas, impondo ao mundo, na Conferência do Rádio realizada em 1963, em Genebra, a alocação do espectro radiofônico internacional em caráter definitivo. Depois que o seu Congresso aprovou em 1962 a propriedade privada de um ralé internacional, através do consórcio privado COMSAT (Communications Satellite Corporation) os EUA se apoderou de $61 \%$ do espectro radioelétrico mundial, o que foi feito através de um acordo firmado entre países em 1964 em que se criou um Sistema Internacional de Comunicação (INTELSAT). Para mais, ver: SCHILLER, 1976, p. 143 
livre fluxo de informação, aos poucos fez emergir, entre os países que participavam dos debates na UNESCO, uma compreensão de que o conteúdo da programação era o que de fato interessava, por sua capacidade de determinar a orientação social de um país e estabelecer em seus padrões culturais características que persistem ao longo do tempo.

Mas, por outro lado, embora a máxima de Marshall McLuhan de que "o meio é a mensagem" ainda estivesse por nascer, os especialistas da Guerra Fria sabiam muito bem do qual mensagem interessava aos desenvolvedores das novas tecnologias. Em uma coletiva de imprensa, o presidente Eisenhower já havia deixado claro que os objetivos dos Estados Unidos na Guerra Fria não era a conquista de territórios nem a subjugação pela força, mas algo mais sutil,

mais penetrante e mais completo. Estamos tentando levar o mundo, através de meios pacíficos, a acreditar na verdade. Essa verdade é que os norteamericanos querem um mundo em paz, um mundo em que todas as pessoas tenham oportunidade do máximo de desenvolvimento individual. Os meios que empregamos para disseminar essa verdade são comumente chamados de 'psicológicos'. Não tenham medo desse termo, simplesmente por ele ser uma palavra de cinco dólares e cinco sílabas. A 'guerra psicológica' é a luta pela mente e pela vontade dos homens." 104

A mente, a vontade e também o bolso, se poderia dizer. De acordo com Schiller, a televisão nos Estados Unidos tem como objetivo preencher a necessidade mercantil dos produtores de bens de consumo, de quem recebe financiamento e patrocínio. Para ele, a "matéria dos programas é preparada especialmente para assegurar e manter audiências em massa, escravizadas às delícias do mundo dos consumidores". ${ }^{105}$ E são exatamente as matérias desses programas que buscavam mercados extras em países onde o domínio da tecnologia e de capital financeiro e humano ainda não permitia a capacidade de produzir ao custo exigido pelo novo meio de comunicação televisivo. E os EUA ainda eram o mais importante exportador de matéria de TV.

\begin{abstract}
Além do mais, os fornecedores estão dispostos a distribuir sua mercadoria a preços abaixo do custo da produção (em alguns casos, apenas a uma fração mínima do custo) porque as vendas no estrangeiro são dividendos extras, lucros obtidos de programas que já deram para cobrir mais do que os custos da produção. As vendas adicionais no exterior a preços abaixo do custo visando conquistar mercado desencorajam a produção nacional de programas em todos os países, exceto os mais ricos." ${ }^{, 106}$
\end{abstract}

\footnotetext{
${ }^{104}$ Certifcate of Incorporation of Committee for free Europe. IN: SAUNDERS, Frances Stonor. Quem pagou a conta? A CIA na guerra fria da cultura. Rio de Janeiro, Editora Record, 2008, p. 167.

${ }^{105}$ SCHILLER, 1976, p. 128.

${ }^{106}$ Idem, p. 127.
} 
Foi o francês Jean D'Arcy quem, em 1969, postulou a necessidade de criação de um direito à comunicação, por entender que a amplitude desse direito e do próprio conceito de comunicar não estavam contemplados na Declaração Universal dos Direitos do Homem. Seu trabalho "Les Droits de L'homme à Communiquer" (Os Direitos do Homem a Comunicar), serviu de base para os debates realizados pela UNESCO na década de 70 sobre a proposta de uma Nova Ordem Mundial da Informação e Comunicação (NOMIC), e que culminaram com a produção do relatório “Um Mundo Muitas Vozes”. O texto de D'Arcy criou novos paradigmas no universo da comunicação e dos direitos humanos, contribuindo imensamente para o debate sobre a necessidade de novas legislações que atendessem a uma conjuntura em que a indústria da comunicação de massa era dominante. Em seu documento "Os direitos do homem a comunicar”, de 1983, a UNESCO irá afirmar que

\begin{abstract}
A chegada sucessiva de outros meios de comunicação de massas - cinema, rádio e televisão - da mesma forma que o abuso de todas as propagandas em vésperas da guerra, demonstraram rapidamente a necessidade e a possibilidade de um direito mais preciso, porém mais extenso, a saber, o de procurar, receber e difundir as informações e as idéias sem consideração de fronteiras". ${ }^{107}$
\end{abstract}

Colocando-se por fora da pauta de tensões que naquela conjuntura estabeleciam a diferenças entre os dois blocos na Guerra Fria no interior da UNESCO, o MNA, municiado com os argumentos teóricos propostos por D’Arcy, conseguiu introduzir como prioridade na discussão a necessidade de uma Nova Ordem Internacional de Informação (NOII), tema que, de qualquer forma, aguçou ainda mais o debate. No interior daquela organização havia uma disputa sobre qual deveria ser a prioridade nos assuntos, o que expressava, para além de construções semânticas, todo um caudal ideológico e doutrinário implícitos em seus proponentes. Nestes embates, o bloco ligado aos EUA defendia como prioridade a efetivação dos direitos humanos, civis e políticos e o bloco ligado à URSS argumentava que o importante eram os direitos humanos, econômicos, sociais e culturais. A proposta de uma Nova Ordem Internacional de Informação, embora correlacionada a essas duas outras, revelava a consolidação de uma nova consciência entre os países não-alinhados a respeito da importância da comunicação, além de evidenciar seu papel ao longo das disputas em torno do fluxo de comunicação ocorrido na década de 60.

${ }^{107}$ Os direitos do homem a comunicar. UNESCO, documento n. 39 CIC, 1983, p. 290-291 
A proposição do NOII, cujo nome nos anais da UNESCO passa a ser NOMIC (Nova Ordem Mundial da Informação e da Comunicação), ${ }^{108}$ proporciona um salto de qualidade nos debates da UNESCO sobre o fluxo de informação e comunicação, apontando para a necessidade dimensionar os efeitos que a produção e difusão de bens simbólicos podem alcançar na construção de riquezas materiais, razão pela qual não se poderia escamotear as desigualdades de produção, principalmente as técnicas, que ainda predominava nas relações internacionais. Necessário seria estudar as consequiências da comunicação em sentido único, característica das relações Norte-Sul.

Já em 1972, quando havia sido encaminhada a solicitação para que houvesse uma qualificação do debate sobre a distribuição desigual dos meios de comunicação, a UNESCO se pronunciou sobre as transmissões via satélite, firmando que "as freqüências radioelétricas são um recurso natural limitado pertencente a todas as nações," 109 que implicaria na necessidade de um sistema de cooperação internacional ao invés da concorrência tecnológica que imperava. O que se percebe é que o debate caminhava cada vez mais em direção à uma proposta de cooperação que estava sendo proposta na nova ordem econômica internacional, o que implicava numa definição de uma nova ordem internacional para comunicação, uma melhor compreensão do papel que os meios de comunicação desempenham, a necessidade de políticas públicas de comunicação que articulem a complementaridade entre a cultura e a comunicação, além da urgência de estudos sobre o direito à comunicação. Expressando a correlação de forças existente dentro da UNESCO, à medida que o debate avançava ganhava espaço o entendimento da necessidade de uma ação estatal como forma de garantir a democratização do acesso à informação e educação, o que deveria ocorrer de forma equilibrada, favorecendo ao exercício da cidadania. Para isso surgiram propostas de implantação dos Planos Nacionais de Comunicação (PNC), com o propósito de que, através

\footnotetext{
${ }^{108}$ A discussão sobre uma Nova Ordem Mundial de Informação e Comunicação se deu nos marcos dos debates sobre uma Nova Ordem Econômica Internacional (NOEI) em 1974. Esta se consistiu em um movimento proposto por países em desenvolvimento que pleiteavam tratamento igualitário em relação aos países considerados desenvolvidos,o que demandaria um tratamento preferencial no comércio internacional, por exemplo. Após a aprovação no mês de maio de um Programa de Ação com esse propósito, em dezembro do mesmo ano a Assembléia Geral da ONU aprovou a Carta de Direitos e Deveres Econômicos dos Estados (Resolução 3.281 XXIX), com medidas direcionadas no sentido de promover o progresso econômico e social e a soberania dos países sobre seus recursos naturais. Países como os EUA, Inglaterra, Israel e Alemanha votaram contra esta resolução e foram derrotados. Restou um questionamento jurídico por parte destes, que se negaram a respeitá-la como "dever", mas apenas como um "dever político e moral", ou seja, era apenas uma recomendação sem obrigatoriedade. A conjuntura, marcada pela chamada "crise do petróleo" e pela anterior decretação da livre conversibilidade do dólar, espelha a tensão que pautava os debates na UNESCO. Para mais, ver: SILVA, Luiz Roberto. Direito internacional público. Belo Horizonte, Del Rey Editora, p. 2.

${ }^{109}$ Ata da Conferência Geral da Organização das Nações Unidas para a Educação, Ciência e Cultura - 17ạ reunião, Paris, 1972 - resoluções. Disponível em: http://whc.unesco.org/archive/convention-pt.pdf
} 
de uma ação direta do Estado, o que poderia ocorrer através da ação de meios estatais de comunicação ou mesmo por intermédio da regulamentação que ajustasse os meios privados às metas e objetivos estabelecidos pelo Estado (RAMOS, 1991).

Longe de liquidar a questão, a proposta de implantação de PNC colocou mais lenha no debate internacional sobre comunicação, principalmente pela reação de países como Estados Unidos, Inglaterra e Japão, que viam na possibilidade de existência dos PNCs uma interferência do Estado no pilar da democracia liberal: a liberdade de imprensa.

Foi o aumento das polêmicas e dos questionamentos que levou à proposição de que os problemas relativos à comunicação fossem estudados por uma comissão formada por membros "amplamente representativos da diversidade ideológica, política, econômica e geográfica do mundo" (UNESCO, 1981).

O resultado foi a criação da Comissão Internacional para o Estudo dos Problemas da Comunicação $^{110}$, presidida por Séan MacBride ${ }^{111}$, tendo como sua principal conclusão o documento que ficou conhecido como "Relatório MacBride - Um mundo e muitas vozes". Publicado em maio de 1980, este Relatório apontava para a necessidade de que se estabelecesse uma nova ordem mundial mais justa e eficaz da informação e da comunicação. De acordo com o professor Venício Arthur de Lima, "O Relatório MacBride foi o primeiro documento oficial de um organismo multilateral que reconhecia a existência de um grave desequilíbrio no fluxo mundial de informação, apresentava possíveis estratégias para reverter a situação e reconhecia o direito à comunicação". ${ }^{112}$ Além de fazer uma crítica sistematizada à "comunicação em sentido único"113 característica das relações Norte-Sul, chocando-se com os monopólios internacionais de comunicação, o Relatório propôs a implementação de políticas nacionais de comunicação que viabilizassem a democratização do acesso aos meios, formulando inclusive a proposta de que a comunicação fosse vista como um direito a ser garantido.

\footnotetext{
${ }^{110}$ A Comissão Internacional para o Estudo dos Problemas da Comunicação iniciou seus trabalhos em dezembro de 1977 e dela faziam parte 16 pessoas: Elie Abel (EUA), Hubert Beuve-Méry (França), Elebe Ma Ekonzo (Zaire), Gabriel Garcia Mérquez (Colômbia), Sergei Losev (URSS), Mochtar Lubis (Indonesia), Mustapha Masmoudi (Tunis), Michio Nagai (Japão), Fred Isaac Akporuaro Omu (Nigéria), Bogdan Osolnik (Yugoslavia), Gamal El Oteifi (Egito), Johannes Pieter Pronk (Países Baixos), Juan Somavia (Chile), Boobli George Verghese (Índia), Betty Zimmerman (Canadá). Mais informações sobre a Comissão podem ser encontradas no Relatório - (UNESCO, 1988, pp. $493-494)$.

${ }^{111} \mathrm{O}$ irlandês Seán MacBride, antigo militante do IRA e ativista na luta pela independência da Irlanda, foi fundador da Anistia Internacional, tendo recebido a American Medal of Justice (1975), Lenin Peace Prize (1977) e UNESCO Silver Medal (1980). Partilhou o Prêmio Nobel da Paz em 1974, com Eisaku Sato, primeiro-ministro japonês.

${ }_{112}$ LIMA, Venício A. Regulação das comunicações: história, poder e direitos. São Paulo, Paulus, 2011, p. 241.

${ }^{113}$ Expressão utilizada pelo professor Venício A. de Lima.
} 
O estudo elaborado pela comissão situou o ato de se comunicar numa perspectiva histórica, buscando entender seu papel para o desenvolvimento da humanidade, desde quando a comunicação entre os indivíduos não era mediada. Dessa forma, o desenvolvimento da comunicação, as formas de que se revestiu no passado, seus objetivos e meios de que dispõe, podem se colocar como chave para as perspectivas do futuro. Problemas como a concentração e a propriedade privada desses meios forma estudados, assim como o surgimento de novas tecnologias, vistas como possibilidades em aberto, tanto capazes de contribuir para democratizar quanto para concentrar o acesso aos meios.

O relatório elenca uma série de princípios básicos com o objetivo de contribuir para uma nova ordem internacional de comunicação, mas entendendo que a democratização da comunicação só pode surgir como fruto de um processo histórico. Entre as preocupações listadas pela comissão está o fim dos atuais desequilíbrios e desigualdades; a eliminação dos efeitos negativos de determinados monopólios, públicos ou privados, e a excessiva concentração de poder; a remoção dos obstáculos internos e externos para um livre fluxo e mais ampla e equilibrada disseminação das informações e idéias; a pluralidade de fontes e canais de informação; liberdade de imprensa e de informação; a liberdade para os jornalistas e todos os profissionais nos meios de comunicação; a liberdade inseparável da responsabilidade; preparação dos países em desenvolvimento para buscarem melhoras em suas próprias nações, sobretudo no que diz respeito à aquisição de equipamentos próprios; capacitação de pessoal, recuperação da infraestrutura, além de tornarem os meios de informação e de comunicação sintonizados com suas próprias aspirações e necessidades; compromisso sincero dos países desenvolvidos para ajudar os demais a alcançar esses objetivos; o respeito à identidade cultural de cada povo e ao direito de cada nação para informar o público internacional sobre seus interesses, aspirações e respectivos valores sociais e culturais; o respeito aos direitos de todos os povos para participar de intercâmbios de informação, baseando-se na igualdade, justiça e benefícios mútuos e, respeito aos direitos da coletividade, assim como de grupos étnicos e sociais, para que possam ter acesso às fontes de informação e participar ativamente dos fluxos de comunicação.

De acordo com Puntel, o relatório inovou afirmar a questão fundamental para a existência da NOMIC que é a democratização da comunicação, clamando a necessidade de ultrapassar as barreiras que impedem uma comunicação democrática, o que faz ao afirmar o direito de comunicar. Para isso, aponta como necessário o estabelecimento de novas políticas 
de comunicação, lançando mão de alternativas horizontais, que possibilitem o efetivo acesso e participação de todas as pessoas de forma ativa e não passiva. ${ }^{114}$

A Conferência de Belgrado, realizada em 1980, aprovou a Resolução contendo esses onze princípios que se chocavam claramente com os monopólios da comunicação e defendendo a pluralidade de fontes e identidades culturais. No entanto,

O Relatório e a UNESCO enfrentaram fortíssima oposição dos países hegemônicos e dos conglomerados globais de mídia. No auge da onda neoliberal, em clima de "Guerra Fria" e sob a liderança de Ronald Reagan e Margareth Thatcher, foi lançada uma ofensiva mundial a favor do "livre fluxo da informação", que, ao lado da chamada "liberdade de imprensa", constitui a eterna bandeira excludente utilizada pelos grupos dominantes de mídia". ${ }^{115}$

A pressão exercida por esses países e pelos seus poderosos meios de comunicação fez com que o debate sobre a NOMIC fosse sendo esvaziado dentro da própria UNESCO, que também viu os EUA e Inglaterra suspender suas contribuições financeiras e depois pedir desligamento, alegando "politização do debate". O resultado disso foi um claro recuo no papel da UNESCO durante os anos 90, com as discussões sobre o desequilíbrio do fluxo de informações passando a fazer parte da agenda do GATT (Tratado Geral sobre Tarifas Aduaneiras e Comércio), ignorando as polêmicas sobre a posse dos meios de comunicação e concentrando suas discussões nas metas de modernização nos países em desenvolvimento e no privilégio à produção educativa.

\section{Fases neoliberal e pós-neoliberal}

Os debates sobre os direitos a comunicação na UNESCO tinham como pano de fundo o acirramento da disputa pela hegemonia entre as visões distintas que marcavam aquele mundo bipolar de então, o que resultou em duas grandes transformações que, de acordo com Sader (2009, p. 53),

introduziram o período histórico contemporâneo em escala mundial: a passagem de um mundo bipolar para um mundo unipolar, sob a hegemonia imperial estadunidense, e a passagem de um modelo hegemônico regulador para o neoliberal. Essa combinação produziu um imenso retrocesso histórico e modificações fortemente regressivas na correlação de forças entre os campos fundamentais de enfrentamento político em escala local e mundial.

\footnotetext{
${ }^{114}$ PUNTEL, Joana T. A Igreja e a Democratização da Comunicação. São Paulo, Paulinas, 1994.

${ }^{115}$ LIMA, Venício A. op. cit. p. 241.
} 
Encerrava-se para os países da América Latina o longo ciclo marcado por cinco décadas de desenvolvimento econômico, industrialização e fortalecimento das classes trabalhadoras, substituídos agora pela ideologia da desconstrução do Estado, que em nosso continente deveria ser mínimo, das privatizações do patrimônio público e abolição dos direitos sociais conquistados ao longo de décadas. Criou-se consenso em torno dessas políticas utilizando "forte propaganda internacional, mas jogando também com o fantasma da inflação, o ponto fundamental na América Latina para a criminalização do Estado e a introdução de duras políticas de ajuste fiscal” (SADER, 2009, p. 45).

Nesse quadro geral também foi imposto o estancamento do debate sobre o direito de comunicação, os planos nacionais de comunicação e a necessidade de uma Nova Ordem Internacional. Na contramão das proposições da UNESCO, as privatizações e desregulamentações ocorridas naqueles anos beneficiaram ainda mais os monopólios e transnacionais do setor. De acordo com Ernesto Carmona, chegou-se a uma situação em que

Diez mega corporaciones poseen o controlan los grandes medios de información de Estados Unidos: prensa, radio y televisión. Esa decena de imperios controla, además, el vasto negocio del entretenimiento y la cultura de masas, que abarca el mundo editorial, música, cine, producción y distribución de contenidos de televisión, salas de teatro, Internet y parques tipo Disneyworld, no sólo en el país del norte sino en América Latina y el resto del mundo. ${ }^{116}$

O aumento da concentração dos meios de comunicação em nosso continente se expressou também nas alianças que players como News Corporation, Viacom, Time Warner, Disney, Bertelsmann, e Sony sedimentaram com grupos multimídias regionais pertencentes a dinastias familiares como a dos Marinho, Civita, Frias, Mesquita, Sirotsky, Saad e Sarney (Brasil), Cisneros, e Zuloaga (Venezuela), Noble, Saguier, Mitre, Fontevecchia e Vigil (Argentina), Slim e Azcárraga (México), Edwards, Claro e Mosciatti (Chile), Rivero, Monastérios, Daher e Carrasco (Bolívia), Ardila Lulle e Santos (Colômbia) (MORAES 2009, p. 110). A desnacionalização, as fusões, os acordos operacionais e acionários foram as diretrizes encaminhadas por governos neoliberais em cada um desses países. A NAFTA (Tratado de Livre Comércio com os Estados Unidos e o Canadá) propiciou uma queda abrupta na produção audiovisual mexicana, que caiu de 100 filmes anuais para $25 .{ }^{117} \mathrm{Na}$ Argentina, o governo de Carlos Menem assinou com os Estados Unidos o Tratado de Proteção Recíproca de Investimentos, facilitando a entrada ilimitada de capitais externos nas empresas

\footnotetext{
${ }^{116}$ CARMONA, Ernesto. El control de la prensa, radio y televisión de EEUU. 2007. Fonte: http://www.eldiariointernacional.com/spip.php?article1148 
de telecomunicações. No Brasil, a Lei 10.610, regulamentada em 2002, autorizou ao capital multinacional a aquisição de até $30 \%$ das empresas de comunicação. Quanto à televisão por assinatura via satélite, não há limites estabelecidos ao capital estrangeiro e na TV a cabo, a Net (grupo Globo) e a TVA (grupo Abril) são controladas pelas transnacionais Telmex e Telefonica, que burlaram a legislação. ${ }^{118} \mathrm{O}$ mercado de TV no Brasil, que movimenta em torno de US\$ 3 bilhões anuais, esta na mão de seis famílias, sendo metade somente da Rede Globo.

No âmbito do debate sobre a democratização da comunicação, ocorreu na América Latina o contrário do que propunha o Relatório MacBride, aumentando a fragilidade dos países frente à pressão do livre fluxo de informações defendido pelas corporações americanas. O resultado disso é que "mensalmente, 150 mil horas de filmes, seriados e eventos esportivos norte-americanos são apresentados nas emissoras de TV latino-americanas" (MORAES 2009, p. 116). Com esse concentrado potencial de comunicação,

Os diez grandes imperios comunicacionales ofrece propaganda política, crea opinión pública y persuade en favor de la ideología conservadora; justificó actitudes imperiales como las invasiones de Irak y Afganistán y, en general, moldea las mentes y lava los cerebros. En vez de informar al ciudadano para dotarlo de una visión crítica y vigilante, el control mediático lo transforma en un consumidor pasivo de entretenimiento y en espectador de la política... por televisión. El control interesado de las noticias por parte de los medios más influyentes comienza desde la selección de lo que es "noticia", es decir, la información que se dará a conocer a los ciudadanos e incluye cómo deben conocerla, o sea, la presentación, tratamiento y enfoque de los hechos a través de los "hombres ancla" o presentadores de noticias, las imágenes de televisión o los textos de los grandes periódicos.

Paradojalmente, estos diez grandes imperios mediáticos muestran a Estados Unidos como una democracia ejemplar, regida por el llamado "sueño americano de la libre competencia", donde todos tendrían "iguales posibilidades de triunfar". (...) Lo cierto es que la arrolladora concentración de la propiedad ha hecho desaparecer a numerosos medios locales, en particular radios, periódicos pequeños y empresas periodísticas familiares, cerrando fuentes de trabajo y limitando la "libertad de expresión". ${ }^{119}$

Conquistando o respaldo quase unânime da mídia, da classe política e da intelectualidade, o projeto neoliberal, que "substitui o Estado pela empresa e pelo mercado, o cidadão pelo consumo, a regulação econômica pelo livre-comércio, os espaços públicos pelos shopping centers" (SADER 2009), foi saudado como instrumento de estabilização financeira, saneamento de dívidas públicas e modernização econômica, conseguindo eleger e reeleger

\footnotetext{
118 Idem.

119 CARMONA 2007.
} 
seus adeptos no Brasil (Fernando Henrique), no Peru (Alberto Fujimori), na Argentina (Carlos Menem), entre outros (SADER, 2009, p 50; BORGES, 2009, p. 39).

Entretanto, uma das consequências dessa política do "Estado mínimo" foi a significativa transferência de capital do setor produtivo para o especulativo, bloqueando as possibilidades de expansão econômica e acentuando a concentração de riquezas e a explosão da miséria, agravando o quadro histórico de desigualdades sociais enfrentadas no continente. ${ }^{120}$ De acordo com Chomsky, à medida que o ritmo das políticas neoliberais se incrementou e se intensificou, "reduziu-se a capacidade dos governos de implementar políticas públicas, já que estas começaram a ser realmente determinadas cada vez mais pelo que é às vezes denominado "o parlamento virtual de investidores e credores" (CHOMSKY, 2004).

A crescente revolta desencadeada contra essa situação foi sendo aos poucos canalizada para um ciclo inédito de vitórias eleitorais de candidatos antineoliberais na Venezuela, Argentina, Brasil, Bolívia, Equador, Uruguai, Chile, El Salvador, Paraguai entre outros. De acordo com Boaventura de Souza Santos, essas transformações resultaram do fortalecimento e da visibilidade de movimentos reivindicatórios que no fim dos anos 90 e início do séc. XXI lutaram pela terra, água, fim da dívida externa e das discriminações raciais e sexuais, pela identidade cultural e por uma sociedade justa. ${ }^{121}$ Desde o caracaço venezuelano em $1989^{122}$, a derrubada do governo Collor em 1992 e as manifestações contra as privatizações no Brasil ${ }^{123}$, passando pela insurreição zapatista em Chiapas, no México em 1994, como resposta à assinatura do NAFTA, e os protestos em Seattle contra o G-7, a OMC e o FMI, chegando ao Fórum Social Mundial de Porto Alegre, em 2001, a reação antineoliberal crescia visivelmente. De acordo com de Borges,

\footnotetext{
${ }^{120}$ O professor Emir Sader classifica a hegemonia neoliberal no plano internacional em três fases: surgimento, consolidação e crise. Na primeira, Reagan e Thatcher deram o tom marcadamente conservador, com Pinochet como exemplo mais genuíno e as receitas de Jeffrey Sachs para a Bolívia como limite de seu modelo econômico. A segunda fase correspondeu à chamada "terceira via" personificada por Bill Clinton e Tony Blair, com uma versão supostamente light de neoliberalismo e a adesão da socialdemocracia, como Miterrand, González, FHC, Andrés Pérez, entre outros, beneficiando-se do de um curto ciclo de expansão da economia americana. A terceira fase é marcada pela crise do capitalismo globalizado e fim do pequeno ciclo de expansão, ascensão de George Bush com um tom mais belicista, aliado ao exponencial crescimento da economia chinesa. (SADER 2009, p. 65).

${ }^{121}$ SANTOS, Boaventura de Soauza. O socialismo do século XXI. Carta Maior, 24.05.2007. IN: http://www.cartamaior.com.br/templates/materiaMostrar.cfm?materia id=14181

${ }^{122} \mathrm{~A}$ explosão social, também conhecida como sacudón, que tomou conta das ruas de Caracas, teve como estopim a alta nos preços e o anuncio, pelo governo Perez, de medidas macroeconômicas para superar a crise econômica.

${ }^{123} \mathrm{Em}$ 1983, estudantes organizados pela UNE chegaram a tomar a Bolsa de valores em São Paulo para impedir a privatização da COSIPA (Companhia Siderúrgica Paulista), entrando em confronto com a polícia.
} 
O devastador tsunami neoliberal, que inicialmente seduziu parcelas das camadas médias e dos próprios trabalhadores, não durou muito tempo. (...) Através de várias formas de rebeldia, dos levantes populares que derrubaram 11 presidentes em curto espaço de tempo aos Fóruns Sociais Mundiais deflagrados no Brasil, a resistência cresceu e ganhou protagonismo. No geral, a crescente revolta contra o neoliberalismo desaguou na vitória das forças progressistas nas eleições presidenciais, que adquiriram centralidade na luta política no continente.

Contribui para desencadear este ciclo de vitórias eleitorais de candidatos progressistas em toda a América Latina o crescente isolamento da "política externa belicista de George W. Bush e a rearticulação dos movimentos indígenas na zona andina (Equador e Bolívia) e nas áreas maias (América Central e México)” (MORAES, 2009, p. 101). Com diferentes ênfases nos problemas a serem enfrentados, as novas lideranças populares souberam catalisar o sentimento geral da população assumindo compromissos políticos e econômicos que se contrapunham ao receituário neoliberal, reconstruindo o Estado e o seu poder de atuação de acordo com o equilíbrio alcançado nas disputas hegemônicas.

A primeira mudança ocorreu na Venezuela em 1998, com a eleição do tenentecoronel Hugo Chávez, líder de um levante militar ocorrido em 1992 ecoando a insatisfação e os protestos populares contra a política privatista e neoliberal do presidente Carlos Andrés Perez. Encabeçando uma aliança política chamada Polo Patriótico, que reunia diversas organizações e movimentos populares, Hugo Chávez obteve recordes de votações em 1998 e em 2000, quando submeteu seu mandato a uma ratificação popular.

Em 2002 era a vez do líder operário Luis Inácio Lula da Silva chegar à presidência do Brasil, dando início a um longo processo de mudanças que se impulsionam a partir do resgate do papel do Estado e da retomada das políticas sociais.

Neste mesmo ciclo de mudanças via eleição presidencial estão as vitórias de Nestor e Cristina Kirchner na Argentina em 2003 e 2007; Tabaré Vázquez em 2004 e Pepe Mujica em 2009, no Uruguai; Evo Morales, na Bolívia em 2005; Michelle Bachelet, no Chile em 2005; Rafael Correa, no Equador em 2006; Daniel Ortega na Nicarágua em 2006; e Fernando Lugo no Paraguai em 2008

Levando em consideração que as disputas pela hegemonia para a construção de um Estado ético-político em prol da coletividade pressupõe, como diria Gramsci, que sejam levados em conta os interesses dos grupos sobre os quais a hegemonia será exercida, as diferenças existentes entre esses governos são em função dos condicionantes 
socioeconômicos de cada país e de clivagens políticas que incidem na práxis governamental (MORAES 2009, p. 103). ${ }^{124}$

As diferenças entre os governos são vistas por Boaventura de Souza Santos (2008) sob a ótica dos interesses estratégicos comuns que os norteiam, com destaque para as questões relativas a soberania, às políticas de desenvolvimento e a solidariedade e integração regional, onde se destacam o papel atribuído às políticas públicas. Neste aspecto, o professor Denis de Moraes lembra que há concordância "entre governos progressistas latino-americanos quanto ao caráter estratégico da comunicação, não apenas para formação de consensos sociais, como também para soberania nacional, o desenvolvimento cultural, a integração regional e a cooperação internacional”. ${ }^{125}$

É com este entendimento que percebemos neste inicio de século o retorno de diversas formas de intervenção estatal no debate sobre o direito à comunicação, seja através de iniciativas práticas, como a criação e o fortalecimento de canais públicos de comunicação, seja através de iniciativas de regulamentação do setor, que é o assunto que discutiremos no próximo capítulo.

\footnotetext{
${ }^{124}$ Alguns estudiosos classificam estes governos latino-americanos em dois blocos, sendo o primeiro composto pela Venezuela, Bolívia, Cuba e Equador, com características anti-imperialistas, antineoliberal e nacionalista. 0 segundo bloco inclui os governos que defendem a inclusão e proteção social, mas sem reverter as condicionantes estruturais que geram a pobreza. Para Mais: MORAES 2009, SADER 2009, BORON 2007. ${ }^{125}$ MORAES 2009, p. 116.
} 
CAPÍTULO III: Governos progressistas, políticas públicas e o direito à comunicação. 


\section{1- O retorno das políticas públicas de comunicação na América Latina do século XXI}

Uma característica marcante do momento político que a América Latina esta vivendo desde o início do século é o ressurgimento do debate sobre o direito à comunicação. Entre polêmicas, divergências, pressões e incompreensões, o tema vem fazendo parte da própria dinâmica de mudanças que governos tentam imprimir em seus países, ocupando uma evidente localização estratégica neste processo, derivando, em muitos casos, em iniciativas de políticas públicas. O presente capítulo tem o objetivo de elencar estas iniciativas tomadas por diversos governos latino-americanos no campo da comunicação, tentando desenhar um panorama geral, levantando questões que auxiliem no entendimento de seus significados. Até que ponto estas iniciativas de políticas públicas se inserem no debate contemporâneo sobre o direito à comunicação? Elas conseguem avançar na garantia deste direito? Existem características comuns que apontem estarem em uma mesma direção?

Em que pese o foco desse estudo ser o Brasil e a Venezuela, achamos importante nesta etapa também elencar minimamente outras experiências similares, especificamente as ocorridas na Bolívia, Equador e Argentina, como forma de tentar visualizar um panorama geral. Achamos que esta é uma necessidade que pode ser atendida sem perder de vista nosso objetivo central.

Entendendo as políticas públicas como o fruto das disputas pela hegemonia que ocorrem no interior da sociedade, podemos compreender as atuais iniciativas na área de comunicação como confirmação da tese de que há um consenso sobre o caráter estratégico dos meios de comunicação de massa nestes embates ${ }^{126}$. De acordo com Comparato (2010, p. 13), “a verdade é que o poder político não se apresenta apenas na coação física, mas necessita, também, para ser estável, de um mínimo de obediência voluntária. Ora, esta, nas sociedades contemporâneas, só pode ser obtida com a colaboração dos meios de comunicação de massa”. Sendo as sociedades caracterizadas pelas relações globais, e não mais pessoais, por sua comunicação ocorrer de forma simbológica, um aspecto fundamental para a garantia do direito à comunicação é o que diz respeito à propriedade dos meios de comunicação.

Como já apontava o Relatório MacBride e as discussões que ocorreram nos anos 70 no âmbito da UNESCO, os principais problemas nesta área estão relacionados ao desequilíbrio de fluxo de informação e à existência de monopólios e concentração dos meios de

${ }^{126}$ MORAES, Denis, 2009, p. 116. 
comunicação nas mãos de poucas empresas que, além de tudo, são privadas, não são públicas. Mais de trinta anos depois, o diagnóstico do Relatório MacBride mantém a sua atualidade nas principais características que detectou e que não mudaram ainda hoje, quais sejam, a imensa concentração da produção, circulação e consumo de produtos comunicativos, as enormes disparidades mundiais, regionais e nacionais, além da transnacionalização das empresas de comunicação. O Relatório apontou também o próprio processo de circulação do capital como maior causador da concentração das empresas de comunicação:

A industrialização tende a estimular a concentração da comunicação, mediante a formação de monopólios ou oligopólios, em matéria de coleta, armazenamento e difusão da informação. A concentração age em três direções: a) integração horizontal e vertical de empresas que agem no setor informativo e recreativo; b) participação de empresas pertencentes a ramos industriais diferentes e interessadas na expansão dos meios de comunicação social (cadeia de hotéis e de restaurantes, companhias aéreas, construtores de automóveis ou empresas de mineração interessadas na imprensa, na produção de filmes e até mesmo no teatro); c) fusão e interpenetração de diversas indústrias da informação criação de grandes conglomerados que abarcam vários meios de comunicação social. (...) Em resumo, a indústria da comunicação é dominada por um número relativamente pequeno de empresas que englobam todos os aspectos da produção e da distribuição, situam-se nos principais países desenvolvidos e cujas atividades são transnacionais. A concentração e transnacionalização são as consequências, talvez inevitáveis, da interdependência das diversas tecnologias e dos diversos meios de comunicação, do custo elevado do trabalho de pesquisa e desenvolvimento, e da aptidão das firmas mais poderosas, quando se trata de introduzir-se em qualquer mercado. Essas tendências existem em muitas outras indústrias, mas a comunicação constitui um setor especial. Às empresas transnacionais cabe uma responsabilidade especial no mundo atual, já que a sua posição dominante em matéria de informação faz delas um elemento da estrutura que determina o desenvolvimento dos modelos econômicos e sociais. Os meios de comunicação transnacionais exercem uma influência capital sobre as ideias e as opiniões, sobre os valores e os estilos de vida e, por conseguinte, sobre a evolução, para o bem ou para o mal, de todas as sociedades. (UNESCO, 1983).

Embora constatando que os meios de comunicação estão imersos em uma lógica que leva à concentração, o Relatório não relativiza a importância destes no mundo atual, por se constituir em um segmento a quem cabe uma responsabilidade especial pelas influências que exerce. Como vimos no capítulo anterior, o quadro de concentração neste setor se agravou ainda mais nos anos 90, com o processo de privatização levado a cabo no período em que o continente se deslumbrava com as políticas neoliberais, o que fez com que, nos debates e disputas atuais, as constatações expressas no Relatório se tornem atuais.

À contemporaneidade desse diagnóstico se somam as recomendações para que se consiga instaurar um novo equilíbrio no fluxo de informações, o que passa, segundo o 
Relatório, pelo fortalecimento da pluralidade dos meios de comunicação dos países em desenvolvimento, com a devida correção das desigualdades do fluxo de informações entre esses países. Por outro lado, Vale lembrar que o relatório ressalta também que a comunicação é um dos aspectos dos direitos humanos, mas que esse direito

é cada vez mais concebido como o direito de comunicar, passando-se por cima do direito de receber comunicação ou de ser informado. Acredita-se que a comunicação seja um processo bidirecional, cujos participantes indivíduos ou coletivos - mantêm um diálogo democrático e equilibrado. Esta ideia de diálogo, contraposta a de monólogo, é a própria base de muitas das ideias atuais, que levam ao reconhecimento de novos direitos humanos. (UNESCO, 1983).

Ou seja, de acordo com o Relatório da UNESCO, a necessária forma dialógica de comunicação, no mesmo sentido em que apontava Paulo Freire $(1983)^{127}$, se contrapõe ao monólogo imposto pela maneira concentrada e privada como estão organizados os meios de comunicação, o que acaba por interferir na garantia de um direito humano. As propostas de políticas públicas surgem, então, como tentativa de diversificar as fontes e os discursos veiculados, geralmente por intermédio da criação de meios públicos e comunitários, como também através de regulamentações que busquem o equilíbrio entre os diversos segmentos envolvidos nessa disputa. É nesse sentido que o professor Dênis de Moraes define como essencial a participação do poder público nos sistemas de informação e difusão,

através de providencias articuladas que resultem na renovação de leis e maços regulatórios das outorgas de rádio e televisão; na descentralização dos canais de veiculação; no apoio a produções audiovisuais independentes; em maior equanimidade nos acessos ao conhecimento e às tecnologias; na geração e distribuição de conteúdos regionais e locais sem fins comerciais (MORAES, 2009, p. 116).

Para auxiliar na discussão sobre essa participação do Estado, recorreremos a dois itens de um estudo do IPEA (Instituto de Pesquisa Aplicada), publicado em 2010, do capítulo intitulado "Panorama da comunicação em 11 países da Comunidade Ibero-Americana". A pesquisa foi publicada sob o título "Panorama da comunicação e das telecomunicações no Brasil”, mas em seus três volumes são abarcados uma ampla gama de aspectos que, em alguns casos, se estende aos países da América Latina.

\footnotetext{
${ }^{127}$ De acordo com MELO (2005), “o conceito de 'comunicação horizontal' ancora-se na proposta de um novo modelo de comunicação - 'humanizado, não elitista, democrático e não-mercantil' -, formulada pelo boliviano Luis Ramiro Beltrán na reflexão intitulada 'Desarrollo rural y comunicación social: relaciones y estratégias' (New York, Cornell University, 1974).
} 
Nesse estudo, o IPEA afirma que "elementos e aparatos (materiais e imateriais) da mediação podem ser úteis para compreender características relevantes de um país, pois a vida pública é hoje fortemente intermediada e construída pela estrutura comunicacional disponível". ${ }^{128}$. Recorreremos a dois indicadores dessa pesquisa, sendo um deles o que trata dos princípios constitucionais e o outro o que versa sobre a coexistência entre modelos de radiodifusão, isso porque estes dois itens são os que estão mais próximos aos temas tratados aqui nesta nossa pesquisa. ${ }^{129}$

O primeiro indicador remete ao princípio de direito positivo, no caso a liberdade de expressão, opinião e de manifestação, característica comum ao modelo de democracia liberal. ${ }^{130}$ Já no segundo indicador, de natureza estrutural-regulatório, procura-se identificar se coexistem diferentes sistemas de radiodifusão nos países pesquisados, ou seja, o modelo comercial, o modelo estatal e o modelo público de comunicação. Os dados apresentados, apesar de oferecem uma visão panorâmica apenas, são úteis, pois podem nos auxiliar a identificar alguns aspectos do quadro das comunicações na América Latina.

Tabela

\begin{tabular}{|l|c|c|}
\hline \multicolumn{1}{|c|}{ PAíS } & $\begin{array}{c}\text { Existência de garantias } \\
\text { constitucionais sobre } \\
\text { liberdade de expressão } \\
\text { ou princípios correlatos }\end{array}$ & $\begin{array}{c}\text { Existência de pelo } \\
\text { menos dois modelos de } \\
\text { radiodifusão }\end{array}$ \\
\hline Argentina & SIM & SIM \\
\hline Brasil & SIM & SIM \\
\hline Chile & SIM & SIM \\
\hline Colômbia & SIM & SIM \\
\hline Equador & SIM & SIM \\
\hline México & SIM & SIM \\
\hline Paraguai & SIM & SIM \\
\hline
\end{tabular}

${ }^{128}$ SILVA, Sivaldo Pereira e VIEIRA, Vivian Peron. Panorama da comunicação em 11 países da comunidade Ibero-Americana. In: Panorama da comunicação no Brasil. Org.: Daniel Castro e outros. Brasília-DF: IPEA, 2011, 3 v. p. 231.

${ }^{129}$ Os outros indicadores pesquisados no capítulo 4 do volume 3 são a implantação do sistema de TV digital; implantação de sistema de radio digital; número de usuários de internet; leitura de jornal impresso; número de instituições de ensino em graduação; e número de instituições de ensino em pós-graduação. Idem.

${ }^{130}$ A liberdade de expressão na democracia liberal brasileira, que Emília Viotti (2007) chama de "liberalismo antidemocrático", é confundida com a liberdade de imprensa. Concordamos com o professor Venício de Lima quando diz que esta, na verdade, é a liberdade dos donos dos meios de impressão, ou seja, é a liberdade de empresa. Para mais, ver: LIMA, Venício. Liberdade de expressão X liberdade de imprensa. Direito à comunicação e democracia. São Paulo, Publisher Brasil, 2010. 


\begin{tabular}{|l|l|l|}
\hline Uruguai & SIM & SIM \\
\hline Venezuela & SIM & SIM \\
\hline
\end{tabular}

Fonte: IPEA, 2010

Em relação ao tópico das garantias constitucionais, a pesquisa do IPEA conclui que, de modo geral, os países têm em suas constituições a comunicação como garantia, afirmando em sua análise final que

todos os países pesquisados sustentam este fundamento em suas cartas magnas. Importante notar que isso inclui aqueles onde têm ocorrido atritos e tensões na relação entre imprensa versus governo (como ocorreu na Venezuela, de Hugo Chavez, no Equador, de Rafael Correa, na Argentina, de Cristina Kirchner e, mais recentemente, no Brasil, de Lula). Significa afirmar que tal princípio esta bem difundido e incorporado no design constitucional destes países, havendo respaldo institucional e legal que coloca o campo da comunicação no bojo do cumprimento dos direitos fundamentais. ${ }^{131}$

Quanto à diversidade dos modelos de radiodifusão, o resultado é similar ao outro item, sendo uma característica generalizada entre esses países pesquisados, mas, no entanto, o Instituto lembra que “por traz do 'sim' existem realidades distintas"132, já que, de acordo com o país, prevalece uma variação entre os modelos estatal e público, ou mesmo uma modalidade ambígua entre um modelo e outro.

O que podemos inferir inicialmente da leitura dessa tabela é que a simples existência de modelos diferentes de comunicação, juntamente com garantias legais sobre o direito de comunicação, pode significar apenas um formalismo que, a rigor, não interfere na prática monopolística preponderante no setor. O professor Venício de Lima (2010, p. 31) defende que a existência de competição entre os meios de comunicação é uma das premissas para reverter esse quadro, o que não poderia ser relegado a um segundo plano na formulação de políticas públicas. Para ele seria necessário uma verdadeira estrutura policêntrica dos meios de comunicação $^{133}$ e a mera presença desse preceito nas normas legais não altera o fato de que esta condição tem sido relegada a um segundo plano. Seriam necessárias formas práticas que garantissem o transito universalista de opiniões, pois

O direito à comunicação significa hoje, além do direito à informação, garantir a circulação da diversidade e da pluralidade de ideias existentes na sociedade, isto é, a universalidade da liberdade de expressão individual. Essa

\footnotetext{
${ }^{131}$ SILVA, Sivaldo Pereira e VIEIRA, Vivian Peron, op. cit., p. 237.

132 Idem, p. 239.

133 Lima firma que o termo "estrutura policêntrica dos meios de comunicação" é utilizado pelo cientista político Giovanni Sartori quando diz que a autonomia da opinião pública depende da existência de uma estrutura "global de centros de influencia e informação diversos". LIMA, op. cit., p. 32.
} 
garantia tem de ser buscada tanto "externamente" - através da regulação do mercado (sem propriedade cruzada e sem oligopólios; priorizando a complementaridade dos sistemas público, privado e estatal) - quanto "internamente" à mídia - através do cumprimento dos Manuais de Redação que prometem (mas não praticam) a imparcialidade e a objetividade jornalística. E tem também de ser buscada na garantia do direito de resposta como interesse difuso, no direito de antena e no acesso universal à internet, explorando suas imensas possibilidades de quebra da unidirecionalidade da mídia tradicional pela interatividade da comunicação dialógica. (LIMA, 2010, p. 36).

Neste mesmo sentido se posicionou a Comissão Interamericana de Direitos Humanos em suas sessões ocorridas no ano de 2000, quando declarou em seu artigo 12 que "os monopólios ou oligopólios na propriedade e controle dos meios de comunicação devem estar sujeitos a leis antimonopólio, uma vez que conspiram contra a democracia ao restringirem a pluralidade e a diversidade que asseguram o pleno exercício do direito do cidadão à informação". ${ }^{134}$ Para um setor marcadamente monopolizado e com imenso poder de agendamento das decisões políticas, simples iniciativas formais muitas vezes não conseguem alterar significativamente o seu quadro excludente e antidemocrático. Por outro lado, a possibilidade de intervenção estatal ainda é motivo de tensões e reações contrárias radicais, que aparecem sempre escudadas na bandeira da liberdade de imprensa. O próprio discurso que ressalta a complexidade do tema contribui para que não somente se iniba o debate, como também, e mais ainda, para que as próprias iniciativas de políticas públicas para o setor sejam paralisadas ou dificultadas.

\section{2- Disputas hegemônicas na América Latina do século XXI}

Uma das evidentes características deste movimento de retomada do debate e das iniciativas de políticas públicas na América Latina é a sua vinculação com o grau de radicalidade nas disputas internas pela hegemonia em cada país entre as forças políticas que ascenderam neste século e as tradicionais. Venezuela, Bolívia, Equador, Argentina ou Brasil, cada um é uma experiência singular em sua trajetória de mudanças, o que também se reflete na forma como o tema da comunicação e das disputas pela produção do imaginário social ganham corpo. Obviamente que essas singularidades interagem e se influenciam mutuamente, inclusive porque o sentido de integração regional vem granjeando força durante este processo. De modo geral, ganham espaço as novas percepções sobre a importância dos meios de

\footnotetext{
${ }^{134}$ Vide anexo. Grifo nosso.
} 
comunicação como alavanca das transformações sociais que esses governos se propuseram a realizar. De acordo com Dênis de Moraes (2009, p. 119),

Há uma série de coincidências nos modos de repensar a atuação do Estado. A começar pelo entendimento de que as questões comunicacionais dizem respeito, na maioria das vezes, aos interesses coletivos. Não podem cingir-se a vontades particulares ou corporativas, pois envolvem múltiplos pontos de vista. Cabe ao Estado um papel regulador, ao mesmo tempo harmonizando anseios e zelando pelos direitos à informação e à diversidade cultural.

A reafirmação e recuperação do papel do Estado tem sido, em diferentes níveis e intensidades, uma temática presente na contemporaneidade latino-americana, evidenciada, inclusive, nas diversas reestatizações ocorridas nos últimos anos. ${ }^{135}$ No âmbito das comunicações, esse processo se reflete numa compreensão oposta à de submissão unilateral desse setor aos interesses do capital e da lucratividade comercial ancorada na massificação.

Em 2007, durante a abertura do V Encontro Mundial de Intelectuais e Artistas em Defesa da Humanidade realizado em Cochabamba, o presidente Evo Morales conclamou jornalistas e intelectuais a ajudarem o governo a "criar consciência popular sobre a importância de os meios de comunicação defenderem os valores da vida, e não os valores do capital, do egoísmo, do individualismo". ${ }^{136}$

Essa declaração do presidente ocorre numa conjuntura marcada, desde o início do seu governo, em 2006, pelo enfrentamento de uma radical oposição dos meios de comunicação, que tentam desacreditar e inviabilizar qualquer mudança no país, processo iniciado já nos primeiros meses, com a nacionalização dos hidrocarbonetos, uma das principais fontes de ingresso boliviano. Da receita gerada com a venda desse recurso mineral, $82 \%$ eram enviados para a Repsol e apenas $18 \%$ ficava no país e ainda malversada pelas oligarquias. Os US\$ 78 milhões anuais que o Estado boliviano recebia saltaram agora para US\$ 2 bilhões. Depois da nacionalização dos hidrocarbonetos, o governo deu início a uma reforma agrária, à convocação de uma Assembleia Constituinte, à erradicação do analfabetismo e também a uma nova lei de telecomunicações. ${ }^{137}$ De acordo com Osvaldo Peredo, parlamentar do MAS (Movimento Ao Socialismo), "um dos graves empecilhos à integração é a avalanche desinformativa, a tirania midiática, pois os meios de comunicação privados adotam uma

\footnotetext{
${ }^{135}$ Além de reestatizações em diversos segmentos da economia ocorridas em vários países, nas telecomunicações se destacam as que foram realizadas na Bolívia e Venezuela (Entel e CANTV). ${ }^{136}$ Fonte: www.alternativabolivariana.org

${ }^{137}$ SEVERO, Leonardo Wexell. Bolívia nas ruas e urnas contra o imperialismo. São Paulo, Editora Limiar, 2008.
} 
postura terrorista em nossos países". ${ }^{138} \mathrm{O}$ grupo espanhol Prisa e alguns latifundiários detém o controle sobre os principais meios de comunicação do país.

Outro presidente, o equatoriano Rafael Correa, propôs que o aspecto crucial no processo de mudanças é a existência, na atualidade, de uma oposição entre o Estado de Direito e o Estado de opinião, afirmando que hoje o continente esta vivendo uma espécie de "medio-cracia" no lugar de uma democracia. Isso se deve ao fato de que os monopólios de comunicação na América Latina tentam se colocar acima das leis e regulamentações, que são vistas como censura. De acordo com ele,

De este problema central se deriva la necesidad de democratizar la propiedad de los medios de comunicación privados e independizarla del dominio de los poderes fácticos; generar mayor cantidad de medios fuera de la lógica de mercado, es decir, medios sin fines de lucro y medios públicos; y acción colectiva a través de adecuada regulación, que busque alinear a las empresas de comunicación con lógica de mercado con los objetivos sociales, esto es, con el derecho ciudadano a recibir información veraz, verificada, oportuna, contextualizada, plural, sin censura previa y con responsabilidad ulterior, como ordena el Art. 18 de nuestra Constitución. (...) Consideramos que la creación y fortalecimiento de los medios públicos al servicio de la ciudadanía, es un hito fundamental para devolver la voz a quienes se les ha escatimado, para elaborar otro tipo de agendas informativas, enfocando temas de verdadero interés y saliendo de la "dictadura del rating y del pautaje publicitario". ${ }^{139}$

Ao colocar ênfase na discussão do ponto de vista da democratização da propriedade dos meios de comunicação privados, o presidente equatoriano avança no debate sobre o poder que estes meios detêm, chegando, inclusive, a se colocar acima do Estado de Direito. A contraposição a esta lógica, que, em síntese, é a lógica mercado, é vista na perspectiva do fortalecimento dos meios públicos de comunicação e do aumento do papel do Estado. $\mathrm{O}$ Equador, país lembrado nas escolas brasileiras unicamente por, junto com o Chile, não fazer fronteira com o nosso e o qual nem mesmo a imaginária Linha do Equador nos proporcionava sensação de proximidade, foi sacudido por manifestações contrárias a assinatura de um Tratado de Livre Comércio com os Estados Unidos, a dolarização da economia e a instalação de uma base militar em Mantra. Em poucos anos, três governos foram derrubados (Abdalá Bucaram, em 1996, Jamil Mahuad, em 2000 e Lucio Gutiérrez, em 2005), por traírem as suas promessas nacionalistas e desenvolvimentistas em troca de políticas neoliberais privatistas, de corte nos investimentos sociais e de submissão ao Fundo Monetário Internacional (FMI),

\footnotetext{
${ }^{138}$ Idem, p. 62.

${ }^{139}$ Conferência Acadêmica pronunciada pelo Presidente Rafael Correa Delgado na Universidade de Columbia Nova York, em 23 de setembro de 2011. Fonte: http://www.presidencia.gob.ec
} 
chegando ao ponto de abolirem a moeda nacional e adotarem o dólar americano. Rafael Correa, eleito nesse embate, declarou ter chegado ao fim a longa noite do neoliberalismo, passando o país a viver, não uma época de mudanças, mas uma mudança de época. A Constituição Plurinacional é a primeira na América Latina que reconhece direitos à natureza, além de adotar o princípio indígena do bom viver (sumak kawsay) como modelo de desenvolvimento. ${ }^{140}$ Ao defender uma proposta de uma nova lei de comunicação, o presidente justifica, argumentando que

Nuestros gobiernos de cambio profundo enfrentan la ilegítima oposición política de cierta prensa, manipulándonos en nombre de la libertad de expresión. Por eso la urgencia de contar con una nueva Ley de Comunicación, que desde su ámbito de influencia también ayuda a democratizar y desmonopolizar los medios de comunicación con la equitativa redistribución de frecuencias para radio y televisión entre el sector privado, el público y el comunitario, y que armonice la normativa con los derechos de la comunicación e información de última generación, como lo exige el siglo XXI, incorporados ya en el marco constitucional ecuatoriano por obra del actual gobierno. ${ }^{141}$

Na Venezuela, país onde mais se avançou no debate sobre o tema do papel do Estado, o governo do presidente Hugo Chaves é ostensivamente contra o monopólio privado dos meios de comunicação, tendo criado o mais abrangente sistema de comunicação da região, com o Ministério da Comunicação e Informação dando prosseguimento ao projeto do Sistema Nacional de Meios Públicos, com pilares na reestruturação dos veículos governamentais e numa maior articulação com veículos alternativos e comunitários (MORAES, 2009, p. 120). Depois do "golpe midiático"142, ocorrido em 2002, o incentivo a rádios e TVs comunitárias

\footnotetext{
${ }^{140}$ Mais informações consultar: BREDA, Tadeu. O Equador é Verde - Rafael Correa e os Paradigmas do Desenvolvimento. São Paulo, Editora Elefante, 2011.

${ }^{141}$ Conferência Acadêmica pronunciada pelo Presidente Rafael Correa Delgado na Universidade de Columbia Nova York, em 23 de setembro de 2011. Fonte: http://www.presidencia.gob.ec

${ }^{142}$ No dia 11 de abril de 2002, ocorreu na Venezuela um "golpe midiático" organizado e conduzido pelos monopólios comunicacionais daquele país vizinho, que chegou a depor e encarcerar o presidente democraticamente eleito, Hugo Chavez. Após a derrota dos partidos tradicionais, AD e Copei, em 1998 e na eminência de uma nova derrota na eleição que se aproximava, os meios de comunicação privados assumiram claramente a postura e o lugar daqueles partidos tradicionais. Nas palavras do jornalista Clodovaldo Hernandes, do jornal El Universal, que também participou do golpe, “Desde que Hugo Chávez despontou nas pesquisas de opinião, articulou-se uma reação da mídia para impedir o seu crescimento. Quando os meios perceberam que sua eleição era inevitável, tentaram se aproximar. Como não conseguiram, voltaram a atacálo". Houve uma unificação total do conteúdo jornalístico sob o lema "una sola voz", com o tom editorial formatado verticalmente. "A reportagem é divulgada pelas emissoras com o mesmo enfoque, o que impede contradições. Os talk shows e programas de debate escolhiam a dedo os entrevistados. O direcionamento do conteúdo, por absurdo que possa parecer, chegava até aos programas humorísticos, que exploravam as mesmas piadas e preconceitos caricaturais para tratar do presidente", explica o jornalista Renato Rovai (2007). Nas semanas anteriores ao dia 11, os meios de comunicação estimularam um locaute patronal e confrontos nas ruas, resultando em várias mortes. Em seguida, convocaram passeatas que eram transmitidas ao vivo com a
} 
fez com que a expansão desses meios atingisse, em 2010, 116 das 335 cidades venezuelanas. Sendo uma dos maiores produtores de petróleo do planeta, somente neste século a UNESCO pôde declarar o país território livre do analfabetismo, fato estrondosamente ignorado pelos meios de comunicação privados, venezuelanos ou latino-americanos. A disputa pelo controle da estatal do petróleo, a Petróleos De Venezuela SA (PDVSA), finalizada em 2003, deu ao governo a possibilidade de avançar na elaboração de planejamentos como o estabelecido nas Linhas Gerais do Desenvolvimento Econômico e Social da Nação. Neste documento destacam-se objetivos como o de manter a orientação e regulação da economia centralizadas nas mãos do Estado; a concepção universal dos direito sociais; o impulso a diversas formas econômicas sociais alternativas à propriedade privada de mercado; a democracia participativa expandida a diferentes esferas da vida social e política; e a ampliação dos direito humanos, incluindo os direitos dos povos indígenas. De acordo com Margarita Lopez Maya, "o processo venezuelano atual não esta inscrito apenas em uma dinâmica nacional, mas também esta cada vez mais articulado às lutas regionais e internacionais por uma nova ordem internacional multipolar". ${ }^{143}$ Essa avaliação se comprova entre os países latino-americanos no incremento das iniciativas para diversificar mundialmente os parceiros comerciais, juntamente com outras visando o fortalecimento da integração econômica, política e cultural da região.

$\mathrm{Na}$ opinião do professor Leal Filho, no contexto latino-americano, embora tenha havido, nos últimos anos, grandes avanços de integração políticos-econômicos entre os Estados da América do Sul, como a criação do Mercosul, da Unasul e da CELAC Comunidade de Estados Latino-americanos e Caribenhos, no campo da comunicação estas possibilidades de articulação não aparecem, devido à hegemonia mantida pelos grandes veículos de comunicação. Nesse sentido, Laurindo destaca que a mídia brasileira não difunde valores que são caros à integração latino-americana. "A mídia brasileira não se esforça a divulgar, por exemplo, que o analfabetismo na Venezuela e na Bolívia chegou a zero". ${ }^{144} \mathrm{O}$ processo histórico de desintegração entre os países da América Latina é o que se fortaleceu

\footnotetext{
insignia "ni un paso atrás!".Militares depuseram e prenderam o presidente. A reação surgiu dos morros que cercam Caracas, de dentro das rádios comunitárias e da TV Cátia, emissora comunitária que exibiu imagens das gigantescas manifestações populares exigindo a volta do presidente ao Palácio Miraflores, revelando ao país outra versão da história. Mesmo depois da derrota do golpe e do retorno de Hugo Chavez ao palácio, nenhuma emissora realizou a cobertura desse fato, provocando um apagão informativo sem precedentes na história da América Latina. Para mais informações sobre o assunto, ver: ROVAI, Renato. Midiático poder. O caso Venezuela e a guerrilha informativa. São Paulo, Editora Publisher, 2007.

${ }^{143}$ MAYA, Margarita Lopez. Venezuela. IN: Enciclopédia contemporânea da America Latina e do Caribe. São Paulo, Boitempo, 2008.

${ }^{144}$ LEAL FILHO, Laurindo Lalo. Radio e TV Pública, um desafio para o Brasil. IN: Comunicação pública no Brasil, uma exigência democrática. São Paulo, Anita Garibaldi, 2009, p. 32.
} 
com a prática dos monopólios de comunicação que vem se empenhando sistematicamente em identificar o continente com imaginários sociais externos.

A Argentina é o país que sofreu o mais radical processo de destruição do Estado durante esta fase, chegando ao fundo do poço em 2001, depois que sucessivos governos se esmeraram na aplicação da receita neoliberal, o que provocou o empobrecimento extremo da população. De exemplo de riqueza e desenvolvimento na década de 50, em 2002 o país exibia uma taxa de pobreza na casa dos $57 \%$ da população, além de $27 \%$ de indigentes. O fenômeno do surgimento dos "nupos" (nuevos pobres), causado pelo empobrecimento da classe média, apareceu no rastro da destruição dos sistemas público de educação e de saúde e das privatizações generalizadas, o que incluiu a Yacimientos Petrolíferos Fiscales (YPF), a mais importante empresa argentina.

As eleições de Nestor e Cristina Kirchner representaram um desvio de rota, ao buscar a recuperação do papel do Estado na economia, o que fez com que os principais veículos de comunicação do país se colocassem abertamente em conflito com o governo. Tanto na Argentina, quanto no Brasil, os grupos monopolistas da comunicação cresceram na intimidade com as ditaduras militares, que as incentivaram e delas extraíram benefícios. Mas a monopolização do setor foi incrementada de forma vertical e horizontal nos anos dos governos neoliberais mediante radical processo de liberalizações, mudanças de leis e de aquisições. De acordo com Natalia Calcagno, coordenadora do Sistema de Informação Cultural do Mercosul (SICSUR),

La propiedad de los medios de comunicación (TV, radio y publicaciones periódicas) en la Argentina actual se encuentra fuertemente centralizada. Esta concentración es identificable según tres direcciones: horizontal (adquisición de varios medios de comunicación del mismo tipo), vertical (adquisición de empresas de otras áreas que conforman la cadena de valor, por ejemplo, una licenciataria de TV se convierte en productora de contenidos) y conglomeral (diversificación de la presencia corporativa en distintas esferas de los medios de comunicación y en sus auxiliares, nuevas tecnologías de la información y la comunicación). Estos tres tipos de concentración se profundizaron, con extraordinaria fuerza, desde la década del noventa. Hoy, los seis grandes grupos multimedios (Clarín-Artear, Admira-Telefónica, América Multimedios, HMT\&F, Grupo Hadad y La Nación) controlan o tienen participación accionaria en alrededor de 200 medios de comunicación. ${ }^{145}$

As tentativas de imprimir novos rumos ao país sempre encontra nesses grupos a oposição militante, o que se viu recentemente quando incentivaram o boicote do agronegócio, o que quase levou a Argentina ao desabastecimento em 2008. Mas, com o prestígio de sua

\footnotetext{
${ }^{145}$ Informações retiradas do artigo "Medios y fines", publicado em: http://www.pagina12.com.ar (21.05.2008).
} 
política, o governo de Cristina Kirchner conseguiu avanços em políticas públicas que fortaleçam a comunicação pública além de aprovar a Ley de Servicios de Comunicación Audiovisual, dando um exemplo fundamental para os países da região no sentido de enfrentar os monopólios dos meios de comunicação e democratizar o setor, sendo esta uma das mais importantes leis de comunicação que surgiram na América Latina neste processo.

O Brasil, onde os monopólios de comunicação também atuam claramente como bloco de poder, todas as propostas de políticas públicas para o setor de comunicações enfrentaram uma acirrada oposição desses meios, sendo muitas delas descartadas ou engavetadas. Em 2005, o primeiro governo do presidente Luis Inácio Lula da Silva teve que fazer frente a uma das mais acirradas campanhas de desestabilização que objetivava enfraquecer as ações governamentais e inviabilizar sua reeleição. Uma bateria de denúncias, escândalos e acusações ${ }^{146}$ foram feitos com o objetivo de levar o governo a sangrar até cair, chegando ao ponto de, na prática, substituir o artigo $5^{\circ}$ da Constituição brasileira ${ }^{147}$, que garante a presunção de inocência, pela presunção de culpa, destruindo reputações de acordo com seus interesses.

Somente depois de derrotar esse golpismo e conseguir se reeleger, sempre com base numa política antineoliberal, é que o governo Lula colocou em pauta o tema da comunicação e das políticas públicas. De acordo com Tereza Cruvinel,

Nestes últimos dois anos, a sociedade brasileira discutiu comunicação pública como nunca antes havia discutido. Anteriormente, houve um debate sobre o assunto durante a Constituinte de 1988, no momento de nossa refundação democrática. Deste movimento resultou o artigo 223, que prevê a complementaridade entre os sistemas privado, estatal e público. (...) Até que em 2007, o debate sobre a comunicação pública recobrou força e ganhou impulso a partir da iniciativa do então Ministro da Cultura, Gilberto Gil, de realizar o Fórum da TV Pública, que reuniu um elenco de entidades e personalidades engajadas na luta pela redemocratização da comunicação". ${ }^{148}$

O importante resultado desse processo de debate foi a Medida Provisória (MP) 398, convertida pelo Congresso Nacional na Lei 11.652, que criou a Empresa Brasileira de Comunicação (EBC), holding de um sistema que opera a TV Brasil, o canal NBR e o canal

\footnotetext{
${ }^{146}$ John B. Thompson desenvolveu o conceito de "Escândalo Político Midiático" (EPM) para classificar essa prática dos meios de comunicação. Sua teoria é de que o EPM surge de uma mistura de jornalismo investigativo com o aumento do poder massificante desses meios, aliado à disseminação de tecnologias de comunicação e informação. Situa-se no campo das disputas simbólicas que garantem e alimentam a crença na legitimidade de um político. A reputação, como aspecto do capital simbólico de um político, entra em jogo com o uso do EPM. Para mais: THOMPSON, John B. O escândalo político - Poder e visibilidade na era da mídia. São Paulo, Editora Vozes, 2002.

${ }^{147}$ Esse artigo estabelece que "Ninguém será considerado culpado até o transito em julgado de sentença penal condenatória".

${ }^{148}$ CRUVINEL, Tereza. O desafio de construir a EBC. IN: Comunicação pública no Brasil, uma exigência democrática (Org. Renata Mielli). São Paulo, Anita Garibaldi, 2009, p 15.
} 
Integración. Outro passo de grande relevância dado pelo governo foi a convocação da $1^{\mathrm{a}}$ CONFECOM (Conferência Nacional de Comunicação) em 2009, que contou com uma massiva participação, com mais de 1.600 delegados eleitos em conferências estaduais nos 27 estados da federação, representando os diversos segmentos da sociedade e governo.

Apesar destes importantes avanços em políticas públicas de comunicação, o governo cedeu às pressões dos meios e arquivou o projeto de classificação indicativa para menores, deixando à critério dos monopólios de comunicação a exposição de crianças e jovens à cenas impróprias ao seu desenvolvimento. Também houve um recuo no arquivamento do projeto da ANCINAV (Agência Nacional de Cinema e Audiovisual), que criava mecanismos para retirar a produção cultural das mãos exclusivas do mercado ${ }^{149}$. Outro recuo foi o abandono do projeto de criação de um Sistema Brasileiro de TV Digital, adotando-se o sistema japonês, em beneficio do monopólio da Rede Globo ${ }^{150}$. Para o professor Venício de Lima (2011, p. 49), um balanço desse período revela

Sem dúvida, que houve avanços. Por outro lado, é também inegável que não se avançou e houve até mesmo retrocesso em algumas áreas fundamentais. Em diferentes ocasiões ficaram evidentes a impotência do Estado e as contradições entre as forças políticas internas ao próprio governo, assim como ficou claro o enorme poder histórico dos grupos tradicionais de mídia, ainda capazes de interferência direta na própria governabilidade do pais. Permanece em aberto, por exemplo, a necessária e inadiável regulação do setor de comunicações, sobretudo, diante da chamada "convergência de mídias".

O é perceptível é que nos diferentes países existem embates, disputas, avanços e retrocessos, onde diversas forças que estão no poder ainda são contra-hegemônicas e estão em busca de alternativas para dar conta do extenso processo de construção de um novo imaginário social. Nesse mesmo sentido, é importante ponderar também que os temas das políticas públicas e do direito à comunicação sofreram uma longa e poderosa campanha de criminalização, barreiras ideológicas e de preconceitos durante os anos de neoliberalismo, sendo classificados, inclusive, tanto na academia quanto na sociedade civil como um "nãoassunto". ${ }^{151}$ Sem dúvida, no plano das disputas ideológicas, o tsunami neoliberal pautou a

\footnotetext{
${ }^{149}$ O projeto transformaria a ANCINE (Agencia Nacional de Cinema) em ANCINAV, com o objetivo de regular e fiscalizar a produção e distribuição dos conteúdos audiovisuais.

${ }^{150}$ De acordo com o FNDC, perdeu-se a chance de adotar um modelo que beneficiasse a descentralização do sistema televisivo e reafirmou-se a verticalização na medida em que os monopólios ficaram intactos. Também foi impedida a convergência tecnológica e as vantagens da inclusão social, interatividade e aumento do número de canais. Fonte: www.fndc.org.br

${ }^{151}$ Essa é uma expressão usada pelo professor Laurindo Lalo Leal Filho, alertando para o fato de que "o bloqueio ao acesso a um rádio, e depois a uma televisão, sem publicidade formou gerações alienadas. Para elas o modelo brasileiro era único. Assim como a maioria dos europeus, até a década de 80 , nunca havia se
} 
agenda política e impôs uma forte censura ao debate sobre esse tema, que virou uma espécie de tabu. Como bem definiu o professor Leal Filho, essa é uma discussão que "para muitas pessoas, é difícil de ser dominada, e toda a carga ideológica que vem da radiodifusão privada complica ainda mais o debate". ${ }^{152}$ É o que Lassance (2011) chamava de paradigma neoliberal, referindo-se ao senso comum segundo o qual a comunicação não pode ser assunto estatal se quiser atender aos interesses da sociedade, devendo mesmo se afastar do Estado como única forma de que esse não interfira em suas ações.

Em que pese as resistências que este processo tem despertado, o professor Denis de Moraes (2009, p. 120) distingue algumas matrizes e direções tendenciais que têm identificado as intervenções governamentais na América Latina, sendo elas a reorganização estatal; a criação de novos canais de televisão estatais ou públicos; a proposição de leis que restrinjam a concentração da propriedade e assegurem maior controle público sobre as empresas concessionárias; o apoio à veículos comunitários; incentivo à produção cultural independente; propostas de leis que protejam e estimulem a industria audiovisual nacional e os programas regionais.

\section{3- Políticas públicas e regulamentações em debate}

Nesse universo de contendas, o debate sobre as propostas de regulamentação é o que mais encontra resistências e dificuldades devido ao poderoso lobby dos monopólios. Muito embora exista uma visível articulação de movimentos sociais, entidades e organizações ligadas ao tema, que reivindicam a recuperação do papel do Estado no setor, entendendo que as questões comunicacionais são do interesse público, não tem sido com cordialidade a maneira como esse assunto vem sendo tratado pelos meios de comunicação nos diversos países, sendo este um dos campos de disputa mais acirrados nesta nova conjuntura. No plano da sociedade civil, tem sido notável a demanda pelo estabelecimento de marcos regulatórios democráticos, que estabeleçam normas e mecanismos que impeçam a atual concentração e monopolização e regularize a revise as concessões e outorgas do uso do espaço de radiodifusão. Já os empresários do setor alegam sempre que qualquer iniciativa

deparado com a radiodifusão mantida pela propaganda, aqui nós nunca havíamos vislumbrado a possibilidade de ter uma rede nacional de TV sem sustentação majoritariamente comercial". LEAL FILHO, Laurindo.

"Prefácio", in: INTERVOZES, Coletivo Brasil de Comunicação social. Sistemas públicos de comunicação no mundo - experiências de doze países e o caso brasileiro. São Paulo, Paulus, 2009, p. 14.

152 LEAL FILHO, Laurindo Lalo. Radio e TV Pública, um desafio para o Brasil. IN: Comunicação pública no Brasil, uma exigência democrática. São Paulo, Anita Garibaldi, 2009, p. 34. 
governamental é uma ameaça à liberdade de imprensa. Em que pese a relutância desses setores, a discussão tem avançado com uma série de iniciativas concretas, a exemplo da Ley de Servicios de Comunicación Audiovisual, da Argentina, além de outras leis aprovadas ou em debate pelo continente afora, que trazem questões importantes sobre o papel que a regulamentação tem no sentido de garantir a democratização da comunicação.

No Brasil, percebemos que, além de preocupações com a necessidade de criação de espaços de participação da sociedade civil na gestão das empresas do campo público, com o fortalecimento das rádios comunitárias e com o aumento das programações regionais e independentes, de acordo com as cotas definidas pela Lei 12.485/11, as entidades, movimentos sociais e parlamentares têm reivindicado a

Criação de um Conselho Nacional de Comunicação, com caráter deliberativo, participação democrática e indicação direta pela sociedade de seus membros, além da instalação imediata do Conselho de Comunicação Social do Congresso Nacional; a regulamentação do Artigo 223 da Constituição Federal, que prevê a complementariedade entre os sistemas público, privado e estatal; a implantação de um fundo composto por recursos da contribuição para o fomento da radiodifusão pública e por novas fontes, como a taxação das emissoras comerciais e de aparelhos de TV; e que as televisões e rádios comunitárias possam receber recursos de publicidade de governo e empresas estatais e que parte do Fundo Setorial do Audiovisual, gerenciado pela Agência Nacional do Cinema, seja destinado ao fomento da produção independente em parceria com as emissoras públicas. ${ }^{153}$

Por outro lado, notamos que, tanto no Brasil quanto em outros países da América Latina, estas questões são retratadas da mesma maneira ideologizada pelos proprietários dos meios ou por suas entidades representativas. A Sociedade Interamericana de Imprensa (SIP, na sigla em espanhol), ${ }^{154}$ reagiu com veemência diante da convocação da $1^{\text {a }}$ CONFECOM pelo governo. Segundo esta organização empresarial,

El gobierno está empeñado en promover, con el apoyo de organizaciones no gubernamentales y de movimientos sociales, una Conferencia Nacional de la Comunicación. La iniciativa es preocupante porque prevé interferencias en el contenido generado para las diversas plataformas de los medios. Sus objetivos son: identificar los principales desafíos relativos al sector de la comunicación; realizar un balance de las acciones del poder público en el

\footnotetext{
${ }^{153}$ Fonte: http://www.fndc.org.br

${ }^{154}$ De acordo com LIMA (2010, p. 73), "a SIP é uma velha conhecida daqueles que militam no campo das comunicações na América Latina. Fundada em Cuba, ao tempo de Fulgencio Batista (1943) e com sede em Miami, EUA, a entidade reúne os principais donos de jornais das Américas e é fruto do ambiente de disputa ideológica da "guerra fria", pós-Segunda Grande Guerra. (...) Dentre outras muitas posições que têm tomado ao longo dos anos, a SIP se opõe obstinadamente à revolução cubana; foi contra o sandinismo na Nicarágua; apoiou o golpe contra Salvador Allende no Chile; foi contra o debate sobre a NOMIC, Nova Ordem Mundial da Informação e da Comunicação na UNESCO na década de 1980 e tem sido crítica implacável do governo de Hugo Chávez na Venezuela".
} 
área; proponer directrices para las políticas públicas en el campo de la comunicación; y establecer las acciones gubernamentales prioritarias de acuerdo con esas directrices. ${ }^{155}$

A tentativa de interdição do debate aparece embalada em preocupações com a já antecipada, antes mesmo de que a própria Conferência ocorresse, acusação de interferências governamentais nos conteúdos, ou seja, a acusação de que o governo manobra para censurar os meios de comunicação. Obviamente que o uso da traumática palavra "censura" se deve ao fato dela vir carregada de significados, em uma região marcada por ditaduras militares que censuravam as opiniões divergentes, como forma de prolongar sua permanência no poder.

Esta interdição tem sido feita em todos os lugares onde se procurou discutir o problema da complementaridade entre os sistemas, de forma a acabar com os monopólios privados, como foi o caso da CONFECOM, quando, na ocasião, Paulo Tonet, o representante da Associação Nacional de Jornais (ANJ), declarou que a conferência colocar na pauta e "discutir monopólio e propriedade cruzada é um retrocesso". ${ }^{156}$ No entanto, o Artigo 220 da Constituição brasileira diz que

Art. 220. A manifestação do pensamento, a criação, a expressão e a informação, sob qualquer forma, processo ou veículo não sofrerão qualquer restrição, observado o disposto nesta Constituição.

$\S 1^{\circ}$ - Nenhuma lei conterá dispositivo que possa constituir embaraço à plena liberdade de informação jornalística em qualquer veículo de comunicação social, observado o disposto no art. $5^{\circ}$, IV, V, X, XIII e XIV.

$\S 2^{\circ}$ - É vedada toda e qualquer censura de natureza política, ideológica e artística.

$\S 3^{\circ}$ - Compete à lei federal:

I - regular as diversões e espetáculos públicos, cabendo ao Poder Público informar sobre a natureza deles, as faixas etárias a que não se recomendem, locais e horários em que sua apresentação se mostre inadequada;

II - estabelecer os meios legais que garantam à pessoa e à família a possibilidade de se defenderem de programas ou programações de rádio e televisão que contrariem o disposto no art. 221 , bem como da propaganda de produtos, práticas e serviços que possam ser nocivos à saúde e ao meio ambiente.

$\S 4^{\circ}$ - A propaganda comercial de tabaco, bebidas alcoólicas, agrotóxicos, medicamentos e terapias estará sujeita a restrições legais, nos termos do inciso II do parágrafo anterior, e conterá, sempre que necessário, advertência sobre os malefícios decorrentes de seu uso.

$\S 5^{\circ}$ - Os meios de comunicação social não podem, direta ou indiretamente, ser objeto de monopólio ou oligopólio.

$\S 6^{\circ}$ - A publicação de veículo impresso de comunicação independe de licença de autoridade. ${ }^{157}$

\footnotetext{
${ }^{155}$ Fonte: http://www.sipiapa.org/v4

${ }^{156}$ Fonte: Jornal Folha de São Paulo, 17.03.2009.

${ }^{157}$ Fonte: www.jusbrasil.com.br/ (o grifo é nosso).
} 
Ou seja, é notável a preocupação dos empresários com a possibilidade de que a sociedade civil, juntamente com a sociedade política, debata políticas públicas e estabeleça as prioridades a serem encampadas pelo governo, mesmo que estas sejam absolutamente constitucionais. Se olharmos um pouco acima, no que diz o Relatório MacBride sobre o principal entrave para a democratização da comunicação, veremos que a existência dos monopólios já aparece naquela conjuntura como entrave, como algo a ser resolvido, superado. Considerando que, no tempo que se passou do Relatório para cá, houve uma monopolização ainda maior dos meios de comunicação, consequência do processo de privatizações dos anos de tsunami neoliberal, podemos concluir que, ao contrário do que propunha o Relatório, houve, sim, um retrocesso.

Outro artigo, o 223 deixa ainda mais evidente o objetivo do legislador, ao estabelecer o princípio da complementaridade:

Art. 223. Compete ao Poder Executivo outorgar e renovar concessão, permissão e autorização para o serviço de radiodifusão sonora e de sons e imagens, observado o princípio da complementaridade dos sistemas privado, público e estatal. ${ }^{158}$

À falta de regulamentação desses artigos, que compromete os sistemas público e estatal ao deixá-los à margem nas disputas ideológicas que se travam na sociedade devido ao pequeno espaço que detêm e ao estigma que carregam, se somam as falhas no histórico de concessões e a ausência de discussão com a sociedade sobre as suas renovações. O Coletivo Intervozes ${ }^{159}$ tem denunciado a falta de transparência e de critérios nos processos de outorgas de canais de rádio e televisão, as interferências políticas e irregularidades na obtenção e na renovação de licenças, a inexistência de fiscalização à radiodifusão comercial e a ausência de mudanças estruturais no processo de implantação da televisão digital no país (apud MORAES, 2009, p. 148).

Estas dificuldades têm contribuído para o surgimento daquilo que o professor Venício de Lima chamou de "coronelismo eletrônico", em alusão ao termo usado pelo jurista Nunes Leal para definir as práticas políticas do antigo Brasil rural. Em um estudo sobre concessões de rádios comunitárias, ele percebeu traços comuns com o sistema de dominação e relações políticas da chamada República Velha, fazendo um paralelo com o atual controle dos meios de comunicação e o seu papel no processo político brasileiro. Pela importância dessa proposição, iremos aqui reproduzir um trecho dessa pesquisa:

$(\ldots)$

\footnotetext{
${ }^{158}$ Idem, grifo nosso.

${ }^{159}$ Ver: http://www.intervozes.org.br
} 
A.1 - O Coronelismo

Desde o Império até a República, a estrutura agrária concentradora da propriedade da terra possibilitou o exercício do controle político do município por lideranças locais por intermédio de um complicado sistema de compromissos e troca de favores com as províncias (estados) e a União. $\mathrm{O}$ coronel era o chefe político local e recebia essa designação como oficial da Guarda Nacional, criada ainda no século 19.

A moeda de troca básica dos velhos coronéis era o controle do voto - o chamado "voto de cabresto" -, inicialmente aberto e depois secreto. Como recompensa, eram eles que decidiam sobre a alocação dos recursos orçamentários estaduais e federais no município e faziam as indicações dos nomes que ocupariam os cargos de comando da máquina pública - juiz, delegado de polícia, coletor de impostos, agente dos Correios, professores do ensino público, dentre outros.

Como reafirmou Leal (1980) "o coronelismo era um aspecto local da dominação política, um aspecto local das lutas e dos entendimentos políticos, embora refletindo-se nos círculos mais amplos e contribuindo, por suas características, para dar uma tonalidade própria a toda a vida política do país".

Esse coronelismo da República Velha encontra suas condições ideais de funcionamento num país de população majoritariamente rural, no contexto do poder central do Estado fortalecido, de municípios isolados e tutelados, e da introdução de instituições representativas na política1.

\section{A.2 - O Coronelismo Eletrônico}

O coronelismo eletrônico, por outro lado, é um fenômeno do Brasil urbano da segunda metade do século 20, que sofre uma inflexão importante com a Constituição de 1988, mas persiste e se reinventa depois ela. É também resultado da adoção do modelo de curadoria (trusteeship model), isto é, da outorga pela União a empresas privadas da exploração dos serviços públicos de rádio e televisão e, sobretudo, das profundas alterações que ocorreram com a progressiva centralidade da mídia na política brasileira, a partir do regime militar (1964-1985).

Emissoras de rádio e televisão, que são mantidas em boa parte pela publicidade oficial e estão articuladas com as redes nacionais dominantes, dão origem a um tipo de poder agora não mais coercitivo, mas criador de consensos políticos. São esses consensos que facilitam (mas não garantem) a eleição (e a reeleição) de representantes - em nível federal, deputados e senadores - que, por sua vez, permitem circularmente a permanência do coronelismo como sistema.

Ao controlar as concessões, o novo "coronel" promove a si mesmo e aos seus aliados, hostiliza e cerceia a expressão dos adversários políticos e é fator importante na construção da opinião pública cujo apoio é disputado tanto no plano estadual como no federal.

No coronelismo eletrônico, portanto, a moeda de troca continua sendo o voto, como no velho coronelismo. Só que não mais com base na posse da terra, mas no controle da informação - vale dizer, na capacidade de influir na formação da opinião pública. A recompensa da União aos coronéis eletrônicos é de certa forma antecipada pela outorga e, depois, pela renovação das concessões do serviço de radiodifusão que confere a eles 
poder na barganha dos recursos para os serviços públicos municipais, estaduais e federais. ${ }^{160}$

Constatamos que já existe um projeto tramitando no Congresso Nacional que trata da revisão do regime das outorgas objetivando transformar seu processo mais transparente. A Comissão que o avalia revelou que uma de suas preocupações é com o fato de que 51 parlamentares, ou seja, 10\% dos deputados federais eleitos, além de 28 senadores, controlam diretamente emissoras de rádio e TV, o que comprova a existência de

\begin{abstract}
estreita vinculação entre exercício da função legislativa e controle sobre os meios de comunicação. (...) Esses dados apenas refletem o fato de que, não raro, poder político e propriedade de veículos de comunicação caminham juntos no Brasil. Essa situação constitui-se, inclusive, de uma das características mais marcantes de diversas oligarquias regionais, algumas delas com forte influência nacional. ${ }^{161}$
\end{abstract}

Podemos perceber que a falta de iniciativa do Estado, como principal ator nesse processo, se reflete na constante postergação da elaboração de uma Lei Geral de Comunicação de Massa, que vem sendo prometida a mais de uma década, mas que ainda não se concretizou. A enorme monopolização existente no setor privado comercial favoreceu-se desse fato, da ausência de restrições à propriedade cruzada.

Na Venezuela, a Lei de Responsabilidade Social em Radio e Televisão, ou Lei Resorte, foi sancionada em dezembro de 2004, pela Assembleia Nacional, fixando parâmetros para as concessões, renovação de outorgas e estabelecendo compromissos para o funcionamento das emissoras. Entre as preocupações dos legisladores esta a definição de direitos e deveres de concessionários, governo e usuários do sistema, classificação indicativa da programação, impedimento da censura prévia, entre outras. Diante da alegação da SIP e dos empresários dos meios, de que a Lei fere a liberdade de expressão, houve manifestação do Tribunal Supremo de Justiça do país confirmando a constitucionalidade da mesma.

Após a leitura da Lei Resorte, detivemo-nos em alguns capítulos que poderiam dar pistas ou revelar um sentido em sua proposição, qual seja o de delegar à população plenos poderes sobre o uso do espaço eletromagnético. Pelas acusações que tem sofrido, achamos importante reproduzir alguns trechos ${ }^{162}$ que nos ajudem a avaliá-la melhor e entender qual a sua contribuição para a garantia do direito à comunicação. Logo em seus objetivos gerais a lei estabelece que

\footnotetext{
${ }^{160}$ Retirado de: http://observatoriodaimprensa.com.br/

${ }^{161}$ Fonte: http://www.camara.gov.br/

162 Todos os trechos aqui citados foram retirados de: http://www.leyresorte.gob.ve/ . Os grifos são nossos.
} 
Artículo 3. Los objetivos generales de esta Ley son:

1. Garantizar que las familias y las personas en general cuenten con los mecanismos jurídicos que les permitan desarrollar en forma adecuada el rol y la responsabilidad social que les corresponde como usuarios y usuarias, en colaboración con los prestadores de servicios de divulgación y con el Estado.

2. Garantizar el respeto a la libertad de expresión e información, sin censura, dentro de los límites propios de un Estado Democrático y Social de Derecho y de Justicia y con las responsabilidades que acarrea el ejercicio de dicha libertad, conforme con la Constitución de la República Bolivariana de Venezuela, los tratados internacionales ratificados por la República en materia de derechos humanos y la ley.

3. Promover el efectivo ejercicio y respeto de los derechos humanos, en particular, los que conciernen a la protección del honor, vida privada, intimidad, propia imagen, confidencialidad y reputación y al acceso a una información oportuna, veraz e imparcial, sin censura.

4. Procurar la difusión de información y materiales dirigidos a los niños, niñas y adolescentes que sean de interés social y cultural, encaminados al desarrollo progresivo y pleno de su personalidad, aptitudes y capacidad mental y física, el respeto a los derechos humanos, a sus padres, a su identidad cultural, a la de las civilizaciones distintas a las suyas, a asumir una vida responsable en libertad, y a formar de manera adecuada conciencia de comprensión humana y social, paz, tolerancia, igualdad de los sexos y amistad entre los pueblos, grupos étnicos, y personas de origen indígena y, en general, que contribuyan a la formación de la conciencia social de los niños, niñas, adolescentes y sus familias.

5. Promover la difusión de producciones nacionales y producciones nacionales independientes y fomentar el desarrollo de la industria audiovisual nacional.

6. Promover el equilibrio entre los deberes, derechos e intereses de las personas, de los prestadores de servicios de divulgación y sus relacionados.

7. Procurar la difusión de los valores de la cultura venezolana en todos sus ámbitos y expresiones.

8. Procurar las facilidades para que las personas con discapacidad auditiva puedan disfrutar en mayor grado de la difusión de mensajes.

9. Promover la participación activa y protagónica de la ciudadanía para hacer valer sus derechos y contribuir al logro de los objetivos consagrados en la presente Ley.

Nota-se que há uma preocupação muito clara com a garantia do incentivo à responsabilidade social, recorrendo-se a mecanismos que a promovam e estimulem o envolvimento da sociedade civil nesta atividade. Universalizando o direito à liberdade de expressão e impedindo a censura, a lei abre espaço para que os canais privados de rádio e 
televisão, sempre abertos unicamente aos grupos que detêm o poder econômico, deem espaço para os diversos setores da sociedade. Pautada na promoção dos direitos humanos, ela distribui responsabilidade à participação ativa e protagonista da cidadania.

No capítulo II, sem se omitir em relação aos abusos que em geral vem sendo cometidos na programação, os legisladores também se preocuparam em estabelecer regras de classificação relacionadas à linguagem, saúde, sexo e violência, determinando critérios para os horários livres, o supervisionado e o de adulto, cada um com suas especificações. Vejamos em alguns pontos como a lei trata esse assunto:

\section{Capítulo II}

De la difusión de mensajes

Tipos, bloques de horarios y restricciones por horario

Artículo 7. A los efectos de esta Ley se establecen los siguientes tipos y bloques de horarios:

1. Horario todo usuario: es aquel durante el cual sólo se podrá difundir mensajes que puedan ser recibidos por todos los usuarios y usuarias, incluidos niños, niñas y adolescentes sin supervisión de sus madres, padres, representantes o responsables. Este horario está comprendido entre las siete antemeridiano y las siete postmeridiano.

2. Horario supervisado: es aquel durante el cual se podrá difundir mensajes que, de ser recibidos por niños, niñas y adolescentes, requieran de la supervisión de sus madres, padres, representantes o responsables. Este horario está comprendido entre las cinco antemeridiano y las siete antemeridiano y entre las siete postmeridiano y las once postmeridiano.

3. Horario adulto: es aquel durante el cual se podrá difundir mensajes que están dirigidos exclusivamente para personas adultas, mayores de dieciocho años de edad, los cuales no deberían ser recibidos por niños, niñas y adolescentes. Este horario está comprendido entre las once postmeridiano y las cinco antemeridiano del día siguiente.

A proposição mais interessante que encontramos na Lei Resorte é a que esta disposta em seu capítulo IV, referente à democratização da comunicação. De muito clara, a lei incentiva a participação organizada da sociedade civil no cumprimento de sua responsabilidade com o funcionamento dos meios de comunicação. Busca criar uma consciência de pertencimento no exercício da liberdade de expressão, que deixa de ser exclusivo dos proprietários dos meios e passa a ser uma condição geral, do cidadão. Vejamos o que propõe este capítulo:

Capítulo IV

De la democratización y participación 
Organización y participación ciudadana

Artículo 12. Los usuarios y usuarias de los servicios de radio y televisión, con el objeto de promover y defender sus intereses y derechos comunicacionales, podrán organizarse de cualquier forma lícita, entre otras, en organizaciones de usuarios y usuarias. Son derechos de los usuarios y usuarias, entre otros, los siguientes:

1. Obtener de los prestadores de servicios de radio y televisión, previa a su difusión, información acerca de los programas e infocomerciales, en los términos que establezca la ley.

2. Dirigir solicitudes, quejas o reclamos vinculados con los objetivos generales de esta Ley, a los prestadores de servicios de radio y televisión, y que los mismos sean recibidos y respondidos dentro de los quince días hábiles siguientes a su presentación.

3. Promover y defender los derechos e intereses comunicacionales, de forma individual, colectiva o difusa ante las instancias administrativas correspondientes.

4. Acceder a los registros de los mensajes difundidos a través de los servicios de radio y televisión, que lleva la Comisión Nacional de Telecomunicaciones, de acuerdo con la ley.

5. Participar en el proceso de formulación, ejecución y evaluación de políticas públicas destinadas a la educación para la percepción crítica de los mensajes difundidos por los servicios de radio y televisión.

6. Participar en las consultas públicas para la elaboración de los instrumentos normativos sobre las materias previstas en esta Ley.

7. Presentar proyectos sobre la educación para la percepción crítica de los mensajes o de investigación relacionada con la comunicación y difusión de mensajes a través de los servicios de radio y televisión, y obtener financiamiento de acuerdo con la ley.

8. Acceder a espacios gratuitos en los servicios de radio, televisión y difusión por suscripción, de conformidad con la ley.

9. Promover espacios de diálogo e intercambio entre los prestadores de servicios de radio y televisión, el Estado y los usuarios y usuarias.

Todas las organizaciones de usuarios y usuarias de los servicios de radio y televisión deberán inscribirse en el registro que llevará la Comisión Nacional de Telecomunicaciones. A los fines de optar por el financiamiento del Fondo de Responsabilidad Social deberán cumplir, además, con las formalidades de inscripción ante el Registro Público.

Las organizaciones deberán cumplir con los siguientes requisitos: no tener fines de lucro, estar integradas por un mínimo de veinte personas naturales, que sus integrantes no tengan participación accionaria, ni sean directores, gerentes, administradores o representantes legales de prestadores de servicios de radio y televisión, que no sean financiadas, ni reciban bienes, 
aportes, ayudas o subvenciones de personas naturales o jurídicas públicas o privadas, que puedan condicionar o inhibir sus actividades en promoción y defensa de los derechos e intereses de los usuarios y usuarias de servicios de radio y televisión.

La Comisión Nacional de Telecomunicaciones facilitará, en todo momento, la inscripción de las organizaciones a las que se refiere este artículo. Cuando una organización haya solicitado su registro, habiendo cumplido con todos los requisitos exigidos, y éste no se le haya otorgado dentro del lapso de treinta días hábiles siguientes a la solicitud, se entenderá que dicha solicitud ha sido resuelta positivamente y se procederá al registro y otorgamiento del certificado de inscripción correspondiente.

La Comisión Nacional de Telecomunicaciones establecerá los procedimientos y demás recaudos que deban acompañar la solicitud de registro, de conformidad con la ley.

Se eximen del pago de impuesto, tasas y contribuciones especiales, el registro de las organizaciones de usuarios y usuarias previstos en este artículo.

Cuando las organizaciones de usuarios y usuarias deban acudir a la vía jurisdiccional y resultaren totalmente vencidas en el proceso, el Tribunal las eximirá del pago de costas cuando a su juicio hayan tenido motivos racionales para litigar.

O presidente Hugo Chávez define a Lei Resorte como uma legislação afirmativa em favor da liberdade de expressão e de proteção da cidadania. "Uma emissora de televisão não pode ficar estar incitando ao ódio, isso é um delito. Não pode incitar ao golpe de Estado, isso é um delito. (...) Estamos aplicando a Constituição e a lei, precisamente para resguardar as liberdades, entre elas a sã liberdade de expressão". ${ }^{163}$

No Equador, país que, das sete emissoras de televisão que possui, cinco estão nas mãos de banqueiros, o governo do presidente Rafael Correa conseguiu incluir na nova Constituição aprovada em 2008, no capítulo sobre comunicação, o direito do cidadão à comunicação livre, equitativa, diversificada e includente, cabendo ao Estado promover e garantir a criação de meios que fomentem a liberdade de expressão. Fruto do debate promovido pelo Foro Ecuatoriano de Comunicación, entidade que reúne associações de rádios comunitárias, sindicatos de jornalistas, faculdades de comunicação, entre outros empenhadas na defesa do direito à comunicação e da diversidade cultural, a legislação estabelece também a obrigação do Estado em impedir a concentração e o monopólio da propriedade dos meios, além do controle social a ser feito por ouvidorias públicas. O Conselho Nacional de

${ }^{163}$ Apud: MORAES, 2009, p. 145. 
Radiodifusão e Televisão (Conartel) estabeleceu normas para impedir a monopolização nas outorgas a serem feitas.

Em 2011, foi realizada uma consulta popular em que $61 \%$ da população referendou a criação da Lei Orgânica de Comunicação, proposta pelo presidente em 2009 e motivos de amplos debates desde então. O ponto polêmico foi a proposta de criação de um Conselho de Regulamentação da difusão de conteúdos na televisão, rádio e jornais impressos que com mensagens de violência, sexo ou discriminação, estabelecendo critérios de responsabilização para estes casos. A lei esta sendo questionada pela Associação de Canais de Televisão do Equador, que não concorda com o estabelecimento de garantias do direito de réplica, com a profissionalização obrigatória dos jornalistas, com a possibilidade de fechamento dos canais que desobedecerem as regras, além da criação de um Conselho de Comunicação, com personalidade jurídica e autonomia administrativa e financeira, tendo como objetivo promover e proteger o exercício da comunicação. Nas palavras do presidente Rafael Correa, o processo de aprovação desta lei foi um marco na história do país. "Em clima de paz e democracia, estamos fazendo as maiores mudanças que este país já teve, desde Alfaro, cujos inimigos, de então, a imprensa privada e a igreja, são também nossos inimigos de hoje". ${ }^{164}$

Notamos que na Bolívia o aspecto mais importante da Lei Geral de Telecomunicações, Tecnologias de Informação e Comunicação aprovada pela Assembleia Legislativa Plurinacional é a definição de que o espaço eletromagnético seja dividido em três partes iguais, entre o Estado, as empresas comerciais e as organizações comunitárias indígenas. Nesta divisão, 33\% ficam nas mãos do Estado, 33\%, nas mãos do setor comercial, 17\% nas mãos do setor social comunitário e os $17 \%$ restantes nas mãos dos povos indígenas originários e campesinos.

Este resultado foi fruto do debate e das disputas entre os atores sociais, pois inicialmente, a proposta colocada pelo governo dividia a radiofrequência em $80 \%$ para as empresas privadas e $20 \%$ para o governo. A Associação de Emissoras de Radio e Jornalismo critica a lei, afirmando que o presidente controlará $67 \%$ do espectro, devido a suas relações com as organizações indígenas e sociais, além de que a lei atenta contra a liberdade de expressão. O presidente do Senado, René Martinez, afirma que a nova lei esta dentro dos marcos da Constituição, não havendo nenhuma violação de direitos, portanto.

A definição do objetivo da lei esta no artigo $1^{\circ}$, que o define como sendo o de garantir "o direito humano individual e coletivo à comunicação, com respeito à pluralidade

\footnotetext{
${ }^{164}$ Informações retirada do site do governo: www.presidencia.gob.ec
} 
econômica, social, jurídica, política e cultural da totalidade das bolivianas e dos bolivianos, as nações e povos indígenas originários e camponeses, as comunidades interculturais e afrobolivianas do Estado Plurinacional da Bolívia".

As concessões para o setor comercial passam a ser feitas com base me licitação pública, não mais de acordo com o peso e o lobby empresarial. Quanto ao setor comunitário e dos povos originários, serão feitas através de concursos de projetos, tendo um artigo, o 65 , especialmente para criar o Programa Nacional de Inclusão Social, com o objetivo de financiar projetos que permitam a expansão da informação com interesse social.

Outro exemplo que achamos importante trazer aqui para o debate é o da Ley de Servicios de Comunicación Audiovisual, mais conhecida como "Ley de Medios", recentemente aprovada na Argentina. Avaliando seus capítulos, percebemos que é muito forte a intenção de criar mecanismos que impeçam a monopolização do sistema de comunicação, que democratizem a participação das várias esferas da sociedade civil, além de propor formas concretas, a exemplo das cotas de exibição, de incentivo à produção audiovisual nacional.

O projeto de lei, antes de ser enviado ao Congresso, foi amplamente debatido em todo o país. A base inicial das discussões foram os 21 pontos organizados pela Coalizão Por Uma Radiodifusão Democrática, criada pelo Fórum Argentino de Rádios Comunitárias, e contando com o apoio de personalidades como Adolfo Perez Esquivel e do relator da ONU para os direitos humanos, Frank de La Rue. Mais de 300 organizações da sociedade civil se colocaram de acordo e trabalharam em cima dos 21 pontos que deram a base na redação da lei. Redes de rádios comunitárias, as Mães e Avós da Praça de Maio, sindicatos de trabalhadores da comunicação, universidades nacionais, movimentos de cooperativas, pequenas e médias empresas de rádio e de televisão, todos se uniram para conceber a proposta que se transformou em lei. Os aspectos que de complementaridade, descentralização e horizontalidade, que acabam combatendo aos monopólios, é o que tem gerado reação por parte dos empresários do setor. ${ }^{165}$

\footnotetext{
${ }^{165}$ De acordo com Alfonso Dragon, "la concentración de medios en Argentina tiene nombre y apellido: Grupo Clarín, que es el equivalente rioplatense de O Globo en Brasil o de Televisa en México, no solamente por el alto grado de concentración de empresas mediáticas, sino por su tradicional influencia en la política nacional. Sería extenso enumerar aquí todas las empresas que conforman el Grupo Clarín. La información disponible en internet indica que son decenas las revistas, periódicos, canales de televisión abierta y por cable, emisoras de radio, agencias de noticias, páginas web, servicios de correo y mensajería, empresas organizadoras de eventos, telefonía por internet, y otras que pertenecen al mismo grupo, colocándolo en una posición absolutamente hegemónica en todo el país. El grupo mediático posee el diario Clarín, el diario Olé, el diario La Razón, Radio Mitre S.A. (Cadena Mitre, Cadena 100, Cadena Top 40), la revista Elle (49 por ciento), Teledeportes, Multideportes, Canal 13, TN, Volver, Patagonik Film. Cuenta con 60 por ciento de Trisa, una empresa que explota los derechos de transmisión de Torneos y Competencias y que, a su vez, controla 6 por ciento de TyC
} 
Segundo Frank de La Rue, o relator da ONU para os Direitos Humanos, esta lei é um modelo que deveria servir de exemplo não apenas para América Latina, mas para o mundo todo. Listamos alguns pontos ${ }^{166}$ que, para nós, expressão seu teor:

\section{1- Democratização e universalização}

A regulamentação dos serviços de comunicação audiovisuais em todo o território da Argentina tem o objetivo de desenvolvimento de mecanismos para a promoção da descentralização e da concorrência, visando o barateamento, a democratização e universalização das tecnologias de informação e comunicação.

\section{2- Serviços de interesse público}

Considera-se aos meios de comunicação audiovisuais, em todas as suas atividades sociais, de interesse público, caráter essencial para o desenvolvimento cultural da população, que se manifesta no direito humano inalienável de expressar, receber, divulgar e investigar informações, idéias e pontos de vista sem qualquer censura.

\section{3- Órgãos colegiados}

Criação da Autoridade Federal de Serviços de Comunicação Audiovisual, uma autoridade autárquica e descentralizada, cuja função é a aplicação, interpretação e aplicação da lei. Seu conselho será composto de forma ampla, com representação do poder legislativo, do executivo, por um presidente e um diretor nomeado pelo executivo, além de prestadores de serviço comercial, faculdades de comunicação, meios públicos e trabalhadores da mídia.

\section{4- Audiovisual Defensoria Pública de Serviços de Comunicação}

Criação de Serviços da Defensoria Pública de Comunicação Audiovisual, órgão responsável pelo recebimento e encaminhamento de consultas, denúncias e reclamações do público de rádio e televisão.

\section{5- Fim dos monopólios}

Com o objetivo de impedir a formação de monopólios e oligopólios, a lei coloca limites à concentração, definindo limites máximos sobre o número de licenças e tipo de suporte. O mesmo concessionário só pode ser licenciado para um serviço de comunicação audiovisual em suporte via satélite, até 10 sinais sonoros de transmissão ou cabo (a lei atual permite que uma pessoa detenha 24) e até 24 licenças de radiodifusão por assinatura. Nenhum concesionário deve ser autorizado a prestar serviços a mais de 35 por cento da população total do país. Quem opera um canal de televisão não pode ser proprietário de uma empresa de TV a cabo na mesma localidade, e viceversa. As empresas de telefonia ficam impedidas de prestar serviços de TV a cabo.

\section{6- Os titulares de licenças}

Permissão de participação de capital estrangeiro no limite máximo de $30 \%$.

\section{7- Prazo de licenças}

O prazo para as licenças são de dez anos, prorrogáveis por mais dez anos, após a realização de audiências públicas. Aqueles que obtiveram a renovação ou prorrogação, não poderá solicitar uma nova prorrogação de tempo para qualquer título.

Sports y 75 por ciento de TyC Uruguay; y100 por ciento de Supreme Ticket. También tiene 50 por ciento de la televisión satelital codificada (en sociedad con TyC), y Prima (más conocida como Ciudad Digital), son 250 empresas en total. DRAGON, Alfonso. Sociedad civil protagonista. CIESPAL (http://www.ciespal.net). 166 Informações retiradas de: http://www.argentina.gob.ar/pais/94-ley-de-servicios-de-comunicacionaudiovisual.php 


\section{8- Conteúdo nacional}

Os serviços de televisão devem transmitir pelo menos $60 \%$ da produção nacional, com um mínimo de $30 \%$ de sua própria produção, incluindo notícias locais. Os serviços de TV a cabo devem incluir em sua grade sinais originários de países do MERCOSUL e países latino-americanos. Estações de rádio privados devem transmitir um mínimo de $50 \%$ da produção própria, incluindo notícias ou notícias local. $30 \%$ da música tocada deve ser de origem nacional.

\section{9- Participação da sociedade civil}

Reservas de $33 \%$ dos locais de rádio programadas em todas as bandas de rádio e de televisão terrestre em todas as áreas de cobertura para as organizações sem fins lucrativos. Além disso, aos povos indígenas será permitida para a instalação e operação de $\mathrm{AM}$ e FM de rádio e sinais de televisão.

\section{0- Cinema Nacional}

Os canais de televisão e de cabo deve obrigatoriamente exibir oito estréias de filmes nacionais por ano. A lei atual não prevê quaisquer regras de promoção nacional cinema.

Nota-se que o debate levantado na UNESCO sobre o direito à comunicação resurgiu na América Latina e se expressa em múltiplas formas de embates e disputas pela hegemonia. As iniciativas de políticas públicas estão na agenda dos governos e a regulamentação do setor encontra brechas conjunturais para se concretizar, sempre endossadas pela pressão e participação da sociedade civil. Outra forma de manifestação dessas iniciativas tem sido através do resgate da comunicação estatal e pública, como tem ocorrido em diversos países. A reestruturação da rede não-comercial de comunicação se traduz no surgimento de novos canais de comunicação, sinalizando o fortalecimento e uma revalorização da comunicação pública. Esse movimento aparece na forma de retomada de debates sobre o papel da TV pública, onde diversas posições têm contribuído para uma definição mais precisa sobre esses meios, o que também pode vir a reforçar sua atuação e a sua importância. O fato é que, paralelo ao debate sobre as normas e regulamentações para o setor de comunicação, surgiram novas TVs públicas na Venezuela, no Brasil, Argentina, entre outros lugares. Exemplo disso é a holding EBC, que abarca a TV Brasil o canal NBR e o canal Integración; Na Venezuela a Telesur, a TVes e as empresas estatais Vive TV, Venezolana de Televisión - VTV, Ávila TV, Asemblea Nacional, as cadeias radiofônicas Nacional e Mundial AM, a Agencia Venezolana de Notícias e a Imprensa Nacional. Na Argentina o Canal Encuentro; na Bolívia a Agencia Boliviana de Información e a cadeia radiofônica Patria Nueva; o canal Ecuador TV, primeira emissora estatal do país. 


\section{Considerações finais}

Tentaremos fazer uma finalização deste debate, focando nossa análise nos casos do Brasil e Venezuela, comparando suas iniciativas de políticas públicas e os avanços conquistados em termos de regulamentação. Teremos como pano de fundo as preocupações da NOMIC, juntamente com as novas demandas surgidas neste século.

A percepção do caráter estratégico dos meios de comunicação se expressa nas diversas ações recentes visando o fortalecimento de estruturas públicas de radiodifusão, além da regulamentação do setor, buscando soluções legais que respondam às peculiaridades de cada país. Entre as tendências que têm caracterizado as intervenções governamentais no atual período: reorganização da comunicação estatal; novos canais de televisão nos âmbitos estatal ou público; leis que restrinjam a concentração e assegurem maior controle publico sobre empresas concessionárias de radio e televisão; apoio a mídias alternativas e comunitárias; fomento à produção cultural independente; e leis que estimulem a indústria audiovisual nacional (MORAES 2009).

Uma comunicação mais plural, mais complexa e mais participativa, onde os diversos setores da sociedade possam se expressar, de forma a dar visibilidade às criações culturais endógenas e que fortaleçam a integração, tem se mostrado como matiz programático nessas iniciativas governamentais recentes.

Constatamos que uma série de avanços vem ocorrendo no debate e nas decisões sobre políticas públicas de comunicação na América Latina. Nota-se a retomada dos debates sobre o direito à comunicação, a criação de normas e regulamentações para o setor, que, com variações próprias de cada país, tentam estabelecer responsabilidades para todos os atores envolvidos neste assunto, além do fortalecimento de empresas públicas de comunicação.

O grave desequilíbrio existente no fluxo mundial de informação e comunicação teve sua radiografia construída a partir do Relatório MacBride, que apresentou já na década de 80, estratégias possíveis para reverter a situação. A avalanche neoliberal, iniciada ainda no clima de "guerra-fria", favoreceu a campanha desencadeada contra as propostas da UNESCO, tendo como carro-chefe a bandeira da liberdade de imprensa.

Na avaliação de José Marques Melo, o relatório nasceu com dificuldades conjunturais que o tornavam uma tarefa difícil. Para ele,

Por se tratar de uma solução de compromisso, negociada habilmente durante dois anos, envolvendo interesses complexos e contraditórios, é compreensível que o Relatório MacBride tenha desagradado a gregos e troianos. Tanto assim que ao ser bombardeado pela diplomacia norte- 
americana, com o apoio de vários governos e instituições do mundo capitalista, ele não mereceu a defesa intransigente do bloco comunista, já em processo de desagregação. Essa tarefa foi assumida por intelectuais de renome internacional, bem como por figuras representativas do movimento terceiro-mundista e por instituições de prestígio mundial como a Igreja Católica.

O Relatório continha um alentado diagnóstico sobre a problemática da comunicação no mundo contemporâneo, propondo soluções utópicas para reduzir as desigualdades tecnológicas, os desequilíbrios informativos e as carências cognitivas existentes na geografia do planeta. Não foi sem razão que ele foi rotulado como "missão impossível" por NORDESTRENG, líder da corporação mundial dos jornalistas e conceituado estudioso da comunicação internacional, que sugeria como inexequível a plataforma embasadora da Nova Ordem Mundial da Informação e da Comunicação. ${ }^{167}$

As mudanças conjunturais, representadas pelo fim da guerra-fria e do mundo bipolar, não impediu que o tema do direito à comunicação reaparecesse atualmente com toda a força, como vem ocorrendo na América Latina. O diagnóstico de que o grande obstáculo à democratização da comunicação é a presença dominante de monopólios e oligopólios nos meios de comunicação tem encontrado ressonância nas proposições e documentos produzidos na atualidade pelos movimentos organizados na sociedade civil, com diferenças que refletem a realidade de cada país. Como avalia o professor Denis de Moraes (2009, p.197),

Como verificado, a amplitude das propostas governamentais varia de país para país. O bloco formado por Venezuela, Equador e Bolívia é o mais ativo na proposição de novas legislações de radiodifusão, na reorientação de investimentos culturais e no fomento à difusão não mercantilizada. Nos demais países pouco se fez pela revisão de outorgas de radio e televisão. (...) a consolidação de medidas depende da reconstrução do espaço público latino-americano, após décadas de submissão ao neoliberalismo que culminaram em esvaziamento dos poderes do Estado, privatização desenfreada e concentração midiática.

Em geral, o direito á comunicação tem sido escanteado, muitas vezes com o recurso de dados formais que falseiam a realidade. $\mathrm{O}$ estudo do IPEA tenta mostrar isso ao revelar que formalmente o conjunto de países da América Latina garante em suas leis o direito de comunicação, assim como possuem em sua estrutura um sistema de comunicação baseado na complementaridade. No entanto, o espaço de produção simbólica na America Latina é exorbitantemente privatizado e o direito de comunicação se restringe aos proprietários dos meios.

Podemos perceber que esse tema esta presente de forma central e determinante no debate atual, refletindo seu peso nas propostas de regulamentação que têm sido debatidas e 
aprovadas em diversos países. Na Venezuela, a Lei Resorte, através do incentivo à participação cidadã e dos comitês de usuários estimula a visão crítica e a possibilidade de um maior engajamento da sociedade civil.

O debate na Venezuela tem a marca da radicalização ocorrida com o golpe midiático em 2002. Muito embora a concentração da propriedade dos meios de comunicação seja similar à que ocorre no Brasil, é o processo de disputas hegemônicas pelo poder tem outro grau de radicalização que diferencia em muito os avanços em políticas públicas entre os dois países. Ao pensar o aspecto cultural na sociedade civil como um fator fundamental para a transformação da sociedade política, Gramsci auxilia no entendimento das disputas em torno do Estado, como alvo central das lutas por transformações na sociedade. A disputa no plano das ideias e da cultura, ao se constituir numa possibilidade para os setores populares, tem nos meios de comunicação um alvo importante para conquistar e construir a sua hegemonia. Por outro lado, a dominação não pode parecer dominação. As forças contra-hegemônicas, em seu projeto de poder, também almejam o consentimento da maioria.

Essa característica que diferencia a realidade das disputas em torno das comunicações nos dois países é visível em três aspectos, sendo eles os avanços na regulamentação, o fortalecimento da rede pública de comunicação e o incentivo aos meios comunitários e populares.

Do ponto de vista da regulamentação, essa diferença é mais visível. A Ley Resorte foi criada em 2004 e conseguiu estabelecer normas avançadas que estimulam a participação da sociedade civil de forma organizada na fiscalização e nas proposições para o funcionamento dos meios de comunicação. Através de mecanismos diversos, conseguiu estabelecer um novo paradigma para a liberdade de expressão, desvinculando-a da liberdade de propriedade.

No Brasil a discussão sobre um marco regulatório enfrenta a obstacularização permanente dos meios de comunicação que, pressionando o Congresso Nacional, tem conseguido adiar uma resolução sobre o assunto. Embora a Constituição estabeleça proibições relativas a concentrações e monopólios, isso tem sido burlado ao longo da história. A complementaridade estabelecida no artigo 223 carece de reais investimentos nos setores não comerciais, o que, sem isso, vira letra morta. Como disse Fisher (1982, p. 48):

O direito de comunicar não é uma panaceia para os males do mundo. Não irá resolver os problemas de desenvolvimento, o problema de um fluxo de comunicações mais equilibrado, ou uma distribuição mais justa dos recursos de comunicações - nacional ou internacionalmente. Não irá assegurar a paz mundial, o progresso da educação, ou endireitar as insuficiências do Terceiro Mundo. 
Contudo, achamos necessário concluir que há muito o que se fazer para entender melhor todas as implicações que estão envolvidas neste debate sobre o direito à comunicação. O sentido paulofreiriano, da dialogia, necessariamente esta em contradição com as formas hoje hegemônicas de comunicação no Brasil e na América Latina. As disputas em torno deste assunto crescem e se afirmam como necessidade, para um projeto de integração e harmonia entre nossos países. 


\section{Bibliografia consultada}

ADORNO, Theodor e HORKHEIMER, Max. A indústria cultural - o iluminismo como mistificação das massas. In: Indústria cultural e sociedade. São Paulo: Paz e Terra, 2002 AGGIO, Alberto (org.). Gramsci: a vitalidade de um pensamento. São Paulo: Editora Unesp, 1997.

ALI, Tariq. Piratas do Caribe: o eixo da esperança. Rio de Janeiro: Record, 2008.

ALTHUSSER, Louis. Aparelhos ideológicos de Estado. Rio de Janeiro: Graal, 1983

ANDERSON, Perry. El pensamiento tíbio: Uma mirada critica sobre La cultura francesa. Revista latinoamericana de Ciencias Sociales. Año 1, no. 1 (jun. 2008). Buenos Aires : CLACSO, 2008.

ARIAS, Oswaldo Capriles. "El debate sobre políticas de comunicación en América latina". Humánitas - portal temático em Humanidades. 2 (1), 1989. Disponível em <www.revele.com.ve>.

Ata da Conferência Geral da Organização das Nações Unidas para a Educação, Ciência e Cultura - $17^{\mathrm{a}}$ reunião, Paris, $1972-$ resoluções. Disponível em: http://whc.unesco.org/archive/convention-pt.pdf

BACHELET, Pedro. Gustavo Cisneros, um empresário global. São Paulo: Planeta, 2004.

BARBERO, Jesus-Martin. Desafios da pesquisa em comunicação na América Latina. Boletim INTERCOM, 49/50, São Paulo, 1984 (apud LOPES, 2005).

BAUMAN, Zygmunt. Globalização, as consequências humanas. Rio de Janeiro: Jorge Zahar, 1999.

BELLUZZO, Luis Gonzaga. Ensaios sobre o capitalismo no século XX. São Paulo: editora Unesp, 2004.

BISBAL, Marcelino. La televisión en Venezuela. In: Historias de la televisión en latinoamérica. Barcelona: Gedisa Editorial, 1992.

BOBBIO, Norberto. A era dos direitos. Rio de Janeiro: Campus, 1992.

BOLAÑO, César R. S. Indústria cultural, capitalismo e informação. São Paulo: Hucitec, 2000. BORGES, Altamiro. A ditadura da mídia. São Paulo, Anita Garibaldi. 2009. 
BOURDIEU, Pierre. A economia das trocas simbólicas. São Paulo: Perspectiva, 2007.

BRASIL. Lei número 11.652, que cria a Empresa Brasileira de Comunicação (EBC), 2008. Brasileiro, 2003.

BREDA, Tadeu. O Equador é Verde - Rafael Correa e os Paradigmas do Desenvolvimento. São Paulo, Editora Elefante, 2011.

BUCCI, Eugênio (org.). A TV aos 50. São Paulo: Perseu Abramo, 2000

BUCCI, Eugênio. “A Tv Pública não faz, não deveria dizer que faz e, pensando bem, deveria declarar abertamente que não faz entretenimento". Fórum Nacional de Tvs Públicas Caderno de debates, 2006.

BUCI-GLUCKSMANN, Christine. Gramsci e o Estado. Rio de Janeiro: Paz e Terra, 1980

CABRAL FILHO, Adilson V. "As políticas públicas de comunicação em busca de novos sujeitos históricos". IN: COUTINHO, Eduardo Granja (org). Comunicação e contrahegemonia. Rio de Janeiro, Editora UFRJ, 2008.

CABRAL FILHO, Adilson V. “As políticas públicas de comunicação em busca de novos sujeitos históricos". IN: COUTINHO, Eduardo Granja (org). Comunicação e contrahegemonia. Rio de Janeiro: editora UFRJ, 2008

CACHI, Camilo Valqui \& BAZÁN, Cutberto Pastor (org.). Capital, poder y medios de comunicación: una crítica epistémica. Cajamarca: Upagu, 2009.

CANCLINI, Néstor Garcia. "Cinco dudas sobre La televisión cultural”. Conferência inaugural do Encuentro Internacional de Cultura y Medios, México, junho de 2008.

CANCLINI, Néstor Garcia. A globalização imaginada. São Paulo: Iluminuras, 2003.

CARMONA UlloA, E. Los Amos de la Prensa en América Latina. In: Los Dueños de Venezuela (y los Amos de la Prensa de América Latina). Santiago de Chile: Ediciones del Leopardo/Revista Punto Final/Wordtheque, 2004. Disponível em: http://www.logoslibrary.eu/pls/wordtc/ecommerce.stampa_scheda_1 ?hcodice=70990\&hlingu a=ESCARTA, Mino. O Castelo de âmbar. Rio de Janeiro: Record, 2000.

CARMONA, Beth. (org.). O desafio da TV pública. Rio de Janeiro: TVE Rede Brasil, 2003.

CARMONA, Ernesto. El control de la prensa, radio y televisión de EEUU. 2007. Fonte: http://www.eldiariointernacional.com/spip.php?article1148 
CASTELLS, Manuel. La era de la información. Economía sociedad y cultura. Madrid: Alianza Editorial, 1998.

CASTORIADIS, Cornelius. A instituição imaginária da sociedade. Rio de Janeiro: Paz e Terra, 1982.

COUTINHO, Carlos Nelson. Gramsci: um estudo sobre seu pensamento político. Rio de Janeiro: Civilização Brasileira, 2007

CRUVINEL, Tereza. "TV Pública: o feito e o por fazer". Folha de São Paulo, 5/1/2009.

CRUVINEL, Tereza. O desafio de construir a EBC. IN: Comunicação pública no Brasil, uma exigência democrática (Org. Renata Mielli). São Paulo, Anita Garibaldi, 2009.

DELARBRE, Raúl Trejo. Televisa, el quinto poder. México: Claves latinoamericanas, 1987.

Democratização da Comunicação. Brasília, 2001.

DRAGON, Alfonso. Sociedad civil protagonista. CIESPAL (http://www.ciespal.net).

EAGLETON, Terry. Ideologia. São Paulo, Editora Unesp/Editora Boitempo, 1997

FERREIRA, Maria Nazareth. A comunicação desintegradora na América Latina, os contrastes do neoliberalismo. São Paulo: Edicon-Cebela, 1995.

FISHER, Desmond. O Direito de Comunicar: Expressão, Informação e Liberdade. São Paulo, Brasiliense, 1982.

FOCAULT, Michel. A ordem do discurso. São Paulo: Editora Loyola, 1999.

FREIRE, Paulo. Extensão ou comunicação?. Rio de Janeiro, Editora Paz e Terra, 1983.

GALEANO, Eduardo. Memória del fuego: las caras y las mascaras. La Habana: Casa de las Américas, 1990.

GIFREU, Josep. O Debate Internacional da Comunicação. Barcelona, Ariel Comunicação, GIL, Antonio Carlos. Métodos e Técnicas de Pesquisa Social. São Paulo, Atlas, 1995.

GIRARD JUNIOR, Liráucio. Pierre Bourdieu, Questões de sociologia e comunicação. São Paulo: Annablume, 2007.

GOLDEFEDER, Miriam. Por trás das ondas da Rádio Nacional. Rio de Janeiro: Paz e Terra, 1980. 
GOODE, William J. \& HATT, Paul K. Métodos em pesquisa social. São Paulo: Cia editora Nacional, 1968.

GRAMSCI, Antonio. Cadernos do cárcere. Org. de Carlos Nelson Coutinho, Marco Aurélio Nogueira e Luiz Sergio Henriques. Rio de Janeiro, Civilização Brasileira, 2000.

GRAMSCI, Antonio. Maquiavel, a política e o Estado moderno. Rio de Janeiro: Civilização Brasileira, 2003.

GRUPPI, Luciano. O conceito de hegemonia em Gramsci. Rio de janeiro: Graal, 1978.

HABERMAS, Jürgen. Mudança estrutural da Esfera Pública. Rio de Janeiro, Tempo

HABERMAS, Jurgen. Mudança estrutural na esfera pública. Rio de Janeiro: Tempo Brasileiro, 2003.

HABERMAS. Técnica e Ciência enquanto "Ideologia". In: Os Pensadores, RÜNNEWALD, José Lino ... [et al]. $2^{\text {a }}$ ed. São Paulo: Abril S.A. Cultural, 1983.

HAMELINK, C.J.Direitos Humanos para a Sociedade da Informação. In: MARQUES DE HERZ, Daniel. A história secreta da Rede Globo. Porto Alegre, Tchê, 1985.

IANNI, Octavio. “O príncipe eletrônico” in: Desafios da Comunicação. Orgs: Dowbor, Ianni, Resende e Silva. Petrópolis: Vozes, 2003.

IANNI, Octavio. A ditadura do grande capital. Rio de Janeiro: Civilização Brasileira, 1981. IANNI, Octavio. Formação do estado populista. Rio de Janeiro: Civilização Brasileira, 1975. IANNI, Otávio. Sociologia da sociologia latino-americana, Rio de Janeiro, Civilização Brasileira, 1971, (apud LOPES, 2005).

INTERVOZES. Sistemas públicos de comunicação no mundo. Experiências de doze países e o caso brasileiro. São Paulo: Paulus, 2009

KLEIN, Naomi. A doutrina do choque. A ascensão do capitalismo de desastre. Nova fronteira, Rio de Janeiro, 2008.

LASSANCE, Antonio. Comunicação institucional do poder público. In: Panorama da comunicação no Brasil. Org.: Daniel Castro e outros. Brasília-DF: IPEA, 2011, 3 v.

LEAL FILHO, Laurindo Lalo. Radio e TV Pública, um desafio para o Brasil. IN: Comunicação pública no Brasil, uma exigência democrática. São Paulo, Anita Garibaldi, 2009. 
LEAL FILHO, Laurindo Lalo. Radio e TV Pública, um desafio para o Brasil. IN: Comunicação pública no Brasil, uma exigência democrática. São Paulo, Anita Garibaldi, 2009.

LEAL FILHO, Laurindo. "Prefácio", in: INTERVOZES, Coletivo Brasil de Comunicação social. Sistemas públicos de comunicação no mundo - experiências de doze países e o caso brasileiro. São Paulo, Paulus, 2009.

LEAL FILHO, Laurindo. A melhor TV do mundo: o modelo britânico de televisão. São Paulo: Summus Editorial, 1997.

LEAL FILHO, Laurindo. Prefácio. In: INTERVOZES. Sistemas públicos de comunicação no mundo. Experiências de doze países e o caso brasileiro. São Paulo: Paulus, 2009

LIGUORI Guido. Roteiros para Gramsci. Rio de Janeiro, Editora UFRJ, 2007, p. 209.

LIMA, Venício A. "O poder 'naturalizado' da grande mídia", in: BORGES, Altamiro. A ditadura da mídia. São Paulo: Anita Garibaldi, 2009.

LIMA, Venício A. Regulação das comunicações: história, poder e direitos. São Paulo, Paulus, 2011.

LIMA, Venício Artur de. Regulação das comunicações, história, poder e direitos. São Paulo, Paulus, 2011.

LIMA, Venício. Liberdade de expressão X liberdade de imprensa. Direito à comunicação e democracia. São Paulo, Publisher Brasil, 2010.

LINDER, Doug. The Trials of Alger Hiss: A Commentary. 2003.

LOPES, Maria Immacolata Vassallo de. Pesquisa em comunicação. São Paulo, Loyola, 2005. MARCONDES FILHO, Ciro. O capital da notícia (jornalismo como produção social de segunda natureza). São Paulo: Ática, 1986.

MARINGONI, Gilberto. A Venezuela que se inventa - poder, petróleo e intriga nos tempos de Chávez. São Paulo: Editora Fundação Perseu Abramo, 2004.

MARINGONI, Gilberto. Mídia. IN: Enciclopédia contemporânea da América Latina e do Caribe. São Paulo, Boitempo, 2006.

MARQUES, C. Eduardo. Notas críticas a literatura sobre Estado, políticas estatais e atores 
MARTÍN-BARBERO, Jesús. "Globalização comunicacional e transformação cultural”, in: Por uma outra comunicação. org. Dênis de Moraes - Rio de Janeiro: Record, 2003.

MARX, Karl. A ideologia alemã. São Paulo: Boitempo, 2007

MARX, Karl. O capital. Rio de Janeiro: Civilização Brasileira, 1974, livro 3, v. 6

MATTELART, Armand \& DORFMAN, Ariel. Para ler o Pato Donald: comunicação de massa e colonialismo. São Paulo: Paz e Terra, 2002.

MATTELART, Armand e MATTELART, Michéle. História das teorias da comunicação. São Paulo: Edições Loyola, 2001.

MATTELART, Armand. A globalização da comunicação. Bauru: Edusc, 1996.

MAY, Tim. Pesquisa social. Questões, métodos e processos. Porto Alegre: Artmed, 2004.

MAYA, Margarita Lopez. Venezuela. IN: Enciclopédia contemporânea da America Latina e do Caribe. São Paulo, Boitempo, 2008.

MAZZIOTTI, Nora. La televison em Argentina. IN: História de la televisón em América Latina. IN: OROZCO, 2002.

McLUHAN, Marshall e CARPENTER, Edmund. Revolução na comunicação. Rio de Janeiro: Jorge Zajar, 1960.

McLUHAN, Marshall. Os meios de comunicação como extensão do homem. São Paulo: Cultrix, 1969.

MELO, José; SATHLER, Luciano (Orgs.). Direitos à Comunicação na Sociedade da comunicação no Brasil. Florianópolis: Diálogo, 1996.

MICELI, Sérgio. Estado e Cultura no Brasil. São Paulo: Difel, 1984.

MICELI, Sérgio. Poder, sexo e letras na República Velha. São Paulo: Perspectiva, 1977.

MORAES, Dênis. A batalha da mídia. Governos progressistas e políticas de comunicação na América Latina e outros ensaios. Rio de Janeiro: Pão e Rosas, 2009.

MORAIS, Fernando. Chatô, o rei do Brasil. São Paulo: Companhia das Letras, 1994.

OLIVEIRO, Oscar. Realidade e alternativas para comunicação no processo de integração da América Latina. São Paulo: ECA/USP, 1991. 
OROZCO, Guillermo (Org.). História de La televisión en América Latina. Barcelona: Gedisa Editorial, 2002.

ORTIZ, Renato. Mundialização e cultura. São Paulo: Brasiliense, 1994.

políticos. In: BIB: Boletim Bibliográfico de Ciências Sociais, No 43, 1997).

PORCHMANN, Marcio. O Estado e seus desafios na construção do desenvolvimento brasileiro. São Paulo, Boitempo, Revista Margem Esquerda, n 15, dez. 2010

PORTALES, Diego. "televisão pública na América Latina: Crises e oportunidades”, in: RINCÓN, Omar. Televisão pública: do consumidor ao cidadão. São Paulo: F.E.Stiftung, 2002.

PORTELLI, Hugues. Gramsci e o bloco histórico. Rio de Janeiro: Paz e Terra, 1977

POULANTZAS, N. Poder político e classes sociais. São Paulo: Martins Fontes, 1986

PREBISCH, Raúl. Dinâmica do desenvolvimento latino-americano. Rio de Janeiro: Editora Fundo de Cultura, 1964.

PUNTEL, Joana T. A Igreja e a Democratização da Comunicação. São Paulo, Paulinas, 1994.

RAMOS, Murilo; BAYMA, Israel e LUZ, Dioclécio. Por Políticas Democráticas de Comunicação - Contribuição ao ideário de reconstituição do Fórum Nacional pela

RIBEIRO, Darcy. Aos trancos e barrancos. Rio de Janeiro: Editora Guanabara, 1986.

ROVAI, Renato. Midiático poder, o golpe dos supermeios e o fortalecimento da guerrilha informativa no caso Venezuela. 2003. Dissertação de Mestrado. ECA, USP, SP.

ROVAI, Renato. Midiático poder. O caso Venezuela e a guerrilha informativa. São Paulo, Editora Publisher, 2007.

SANTAELLA, Lucia. Comunicação e Pesquisa: projetos para mestrado e doutorado. São Paulo, Hackers Editores, 2001.

SANTOS, Boaventura de Soauza. O socialismo do século XXI. Carta Maior, 24.05.2007. IN: http://www.cartamaior.com.br/templates/materiaMostrar.cfm?materia_id=14181

SARTRE, Jean-Paul. A imaginação. Porto Alegre: L\&PM, 2008.

SAUNDERS, Frances Stonor. Quem pagou a conta? A CIA na guerra fria da cultura. Rio de Janeiro, Editora Record, 2008. 
SCHILLER, Herbert. Comunicación de masas e imperialismo yanqui. Editorial Gustavo Gili, Barcelona, 1976.

SCHILLER, Herbert. O império norte americano das comunicações. Petrópolis: Vozes, 1976.

SECCO, Lincoln. Gramsci e o Brasil: recepção e difusão de suas idéias. São Paulo: Cortez, 2002.

SERRANO, Franklin (2004). "Relações de poder e política macroeconômica americana, de Bretton Woods ao padrão dólar flexível”. In: FIORI (org). O poder americano. Petrópolis, RJ: Vozes.

SEVERO, Leonardo Wexell. Bolívia nas ruas e urnas contra o imperialismo. São Paulo, Editora Limiar, 2008.

SILVA, Luiz Roberto. Direito internacional público. Belo Horizonte, Del Rey Editora, 1992.

SILVA, Sivaldo Pereira e VIEIRA, Vivian Peron. Panorama da comunicação em 11 países da comunidade Ibero-Americana. In: Panorama da comunicação no Brasil. Org.: Daniel Castro e outros. Brasília-DF: IPEA, 2011.

SKOCPOL, Theda et all. Bringing the State Back In. Cambridge University Press, 1985.

SOUSA SANTOS, Boaventura. "O socialismo do séc. XXI". Carta Maior, 24 de maio de 2007.

SOUZA, Marcio Vieira de. As Vozes do Silêncio: o movimento pela democratização

THOMPSON, John B. O escândalo político - Poder e visibilidade na era da mídia. São Paulo, Editora Vozes, 2002.

UNESCO. Um mundo e muitas vozes: comunicação e informação na nossa época. Rio de Janeiro, 1983.

V. I. LENIN. Que fazer? IN: Obras escolhidas. São Paulo: Alfa-Omega, 1979

VALENTE, Jonas. Televisão pública: da esfera pública ao aparelho de estado. 2008

WERNECK SODRÉ, Nelson. História da imprensa no Brasil. Rio de Janeiro: Graal, 1977.

WILLIANS, Raymond. Palavras-chave. São Paulo, Boitempo, 2007

WOLF, Mauro. Teorias da comunicação. Lisboa: Editorial Presença, 1995. 


\section{Endereços eletrônicos consultados:}

http://arla.radiolivre.org/

http://jus.uol.com.br/revista/texto/140/a-legitimidade-do-poder-de-reforma-constitucional http://www.fndc.org.br

www.jusbrasil.com.br/ (o grifo é nosso).

http://observatoriodaimprensa.com.br/

http://www.camara.gov.br/

http://www.leyresorte.gob.ve/

http://www.pagina12.com.ar (21.05.2008

http://www.presidencia.gob.ec

http://www.sipiapa.org/v4

www.fndc.org.br

www.presidencia.gob.ec

http://www.tves.gob.ve/

http://www.ebc.com.br/

http://www2.tvcultura.com.br/

http://www.telesurtv.net/ 
ANEXOS

\section{Anexo 1 - Resolução de Belgrado}

Trecho retirado do artigo "UNESCO, NOMIC y America Latina. De la Guerra Fria al espíritu de buena voluntad de MacBride”, de José Marques de Melo (1991).

La esencia de las propuestas de la Comisión MacBride se encontró consustanciada en laResolución de Belgrado, aprobada por la vigésima primera sesión de la Conferencia General de la UNESCO, en octubre de 1980 (Shea y Jarret 1984:82-83). Esta resolución contiene once princípios, en los cuales se debería basear el NOMIC (Nuevo Orden Mundial de la Información y de la Comunicación):

1. Eliminación de los desquilibrios y desigualdades que caracterizan la situación vigente.

2. Eliminación de los efectos negativos de determinados monopolios, publicos o privados, y de las excesivas concentraciones.

3. Remoción de los obstáculos internos y externos para un libre flujo de y una más ampla y equilibrada diseminacióm de informaciones e ideas.

4. Pluralidade de fuentes e canales de información.

5. Libertad de prensa y de información.

6. Libertad para los perodistas y para todos los profesionales de los medios de comunicación; una libertad inseparable de la responsabilidad.

7. Habilitación de los países en desarollo para mejorar sus proprias situaciones, sobre todo en lo que respecta a la adquisición de equipo propio, entrenamiento de personal, recuperación de infraestrutuctura, además de capacitación de sus medios informativos y de comunicación, para sintonizarse con sus propias necesidades y aspiraciones.

8. Compromiso sincero de los países desarollados para ayudarlos a lograr tales objetivos.

9. Respeto a la identidad cultural de cada pueblo y al derecho de cada nación para informar al públco internacional sobre sus intereses, aspiracionais y respectivos valores sociales y culturales.

10. Respeto al derecho de todos os pueblos para participar en el intercambio internacional de información, con base en la igualda, la justicia y el beneficio mutuo. 
11. Respeto al derecho de la coletividad, de los grupos étnicos y sociales, así como de los individuso para tener acceso a las fuentes de información y participar activamente en los flujos de comunicación.

\section{Anexo 2 - Plano da UNESCO para 1990-1995}

Trecho retirado do artigo "UNESCO, NOMIC y America Latina. De la Guerra Fria al espíritu de buena voluntad de MacBride”, de José Marques de Melo (1991).

El nuevo plan de la UNESCO para el quinquenio 1990-1995 contiene cuatro metas bien definidas:

1. Inversiones en infraestrutuctura, ampliando y modernizando las redes de comunicaciones de los países en desarollo.

2. Entrenamiento de los recursos humanos, dando prioridad a la producción educativa, la selección de tecnologías apropriadas y la investigación aplicada.

3. realización de estudios sobre el impacto sociocultural de los medios de comunicación de masas y las nuevas tecnologías en la identidad cultural de los pueblos.

4. Desarollo de programas destinados a educar los usuarios de los medios de comunicación, capacitándolos para escoger críticamente las mensajes disponibles, a resistir las posibles manipulaciones y a defender sus derechos como ciudadanos.

\section{Anexo 3}

\section{CARTA DE BRASÍLIA}

Manifesto pela TV Pública independente e democrática

Nós, representantes das emissoras Públicas, Educativas, Culturais, Universitárias, Legislativas e Comunitárias, ativistas da sociedade civil e militantes do movimento social, profissionais da cultura, cineastas, produtores independentes, comunicadores, acadêmicos e telespectadores, reunidos em Brasília, afirmamos, em uníssono, que o Brasil precisa, no seu trilhar em busca da democracia com igualdade e justiça social, de TVs Públicas 
independentes, democráticas e apartidárias.

Nove meses transcorridos desde o chamamento para o $1^{\circ}$ Fórum Nacional de TVs Públicas, uma iniciativa pioneira do Ministério da Cultura, por meio da Secretaria do Audiovisual, com apoio da Presidência da República, podemos afirmar que este nosso clamor soma-se aos anseios da sociedade brasileira. Neste processo, o Brasil debateu intensamente a televisão que quer e pretende construir, quando estamos à porta da transição para a era digital.

Nesse período, superamos a dispersão que nos apartava de nós mesmos e descobrimos uma via comum de atuação, que tem como rota o reconhecimento de que somos parte de um mesmo todo, diverso e plural, complementar e dinâmico, articulado em torno do Campo Público de Televisão. Um corpo que se afirma a partir da sua heterogeneidade, mas compartilha visões e concepções comuns.

Os participantes do Fórum afirmam:

** A TV Pública promove a formação crítica do indivíduo para o exercício da cidadania e da democracia;

** A TV Pública deve ser a expressão maior das diversidades de gênero, étnicoracial, cultural e social brasileiras, promovendo o diálogo entre as múltiplas identidades do País;

** A TV Pública deve ser instrumento de universalização dos direitos à informação, à comunicação, à educação e à cultura, bem como dos outros direitos humanos e sociais;

** A TV Pública deve estar ao alcance de todos os cidadãos e cidadãs;

** A TV Pública deve ser independente e autônoma em relação a governos e ao mercado, devendo seu financiamento ter origem em fontes múltiplas, com a participação significativa de orçamentos públicos e de fundos não-contingenciáveis; 
** As diretrizes de gestão, programação e a fiscalização dessa programação da TV Pública devem ser atribuição de órgão colegiado deliberativo, representativo da sociedade, no qual o Estado ou o Governo não devem ter maioria;

** A TV Pública tem o compromisso de fomentar a produção independente, ampliando significativamente a presença desses conteúdos em sua grade de programação;

** A programação da TV Pública deve contemplar a produção regional;

** A programação da TV Pública não deve estar orientada estritamente por critérios mercadológicos, mas não deve abrir mão de buscar o interesse do maior número possível de telespectadores;

** A TV Pública considera o cinema brasileiro um parceiro estratégico para a realização de sua missão e enxerga-se como aliada na expansão da sua produção e difusão;

** O Campo Público de Televisão recebe positivamente a criação e inserção de uma TV Pública organizada pelo Governo Federal, a partir da fusão de duas instituições integrantes do campo público e promotoras deste Fórum (ACERP e Radiobrás).

E recomendam:

** A nova rede pública organizada pelo Governo Federal deve ampliar e fortalecer, de maneira horizontal, as redes já existentes;

** A regulamentação da Constituição Federal em seu capítulo sobre Comunicação Social, especificamente os artigos 220, 221 e 223;

** O processo em curso deve ser entendido como parte da construção de um sistema público de comunicação, como prevê a Constituição Federal de 1988;

** A construção e adoção de novos parâmetros de aferição de audiência e qualidade que contemplem os objetivos para os quais a TV Pública foi criada; 
** A participação decisiva da União em um amplo programa de financiamento voltado para a produção de conteúdos audiovisuais, por meio de mecanismos inovadores;

** Promover mecanismos que viabilizem a produção e veiculação de comunicação pelos cidadãos e cidadãs brasileiros.

E propõem em face do processo de migração digital:

** Garantir a construção de uma infra-estrutura técnica, pública e única, que viabilize a integração das plataformas de serviços digitais por meio de um operador de rede;

** A TV Pública considera que a multiprogramação é o modelo estratégico para bem realizar a sua missão;

** A TV Pública deve ser promotora do processo de convergência digital, ampliando sua área de atuação com as novas tecnologias de informação e comunicação e promovendo a inclusão digital;

** TV Pública deve se destacar pelo estímulo à produção de conteúdos digitais interativos e inovadores;

** $\mathrm{O}$ apoio à continuidade de pesquisas com vistas à criação de softwares que garantam a interatividade plena;

** Os canais públicos criados pela Lei do Cabo devem ser contemplados no processo de migração digital, passando a operar também em rede aberta terrestre de televisão;

** A TV Pública deve estar presente em todas as formas de difusão de televisão, existentes ou por serem criadas; 
** Trabalhar em conjunto com o BNDES para encontrar mecanismos de financiamento, por meio do fundo social do banco de fomento, da migração digital das TVs Públicas;

** Fomentar o debate sobre a questão da propriedade intelectual no universo digital, buscando ampliar os mecanismos de compartilhamento do conhecimento.

** A força e a solidez do $1^{\circ}$ Fórum Nacional de TVs Públicas são reflexos do envolvimento das associações do campo público de televisão brasileiro - Associação Brasileira de Emissoras Públicas, Educativas e Culturais (Abepec), Associação Brasileira de Canais Comunitários (ABCCom), Associação Brasileira de Emissoras Universitárias (ABTU) e Associação Brasileira de Televisões e Rádios Legislativas (Astral) - e das organizações da sociedade civil, que ao tomarem parte deste processo dele se apropriaram, difundindo-o e ampliando-o.

Ao cabo destes quatro dias de reunião, sob o signo da fraternidade e de uma harmonia construtiva que só se vivencia nos grandes momentos históricos, todos saímos fortalecidos. Acima de tudo, emerge fortalecido o cidadão brasileiro, detentor de um conjunto de direitos que jamais se efetivarão sem a ampliação e o fortalecimento do espaço público também na televisão brasileira.

Pelos motivos que se depreendem da leitura desta carta, é consenso, por fim, que o Fórum Nacional de TVs Públicas deve se transformar em espaço permanente de interlocução e de construção de políticas republicanas de comunicação social, educação e cultura, institucionalizando-se na vida democrática do País.

Brasília, 11 de maio de 2007; I Fórum Nacional de TVs Públicas

Anexo 4 - Declaración sobre los Principios Fundamentales relativos a la Contribución de los Medios de Comunicación de Masas al Fortalecimiento de la Paz y la Comprensión Internacional, a la Promoción de los Derechos Humanos y a la Lucha contra el Racismo, el Apartheid y la Incitación a la Guerra. - 1978 
Declaración sobre los Principios Fundamentales relativos a la Contribución de los Medios de Comunicación de Masas al Fortalecimiento de la Paz y la Comprensión Internacional, a la Promoción de los Derechos Humanos y a la Lucha contra el Racismo, el Apartheid y la Incitación a la Guerra

28 de noviembre de 1978

Preámbulo

La Conferencia General, Recordando que en virtud de su Constitución, la UNESCO se propone "contribuir a la paz y a la seguridad estrechando, mediante la educación, la ciencia y la cultura, la colaboración entre las naciones a fin de asegurar el respeto universal a la justicia, a la ley, a los derechos humanos y a las libertades fundamentales" (art. 1, 1), y que para realizar tal finalidad la Organización se preocupará de "facilitar la libre circulación de las ideas, por medio de la palabra y de la imagen" (art. 1,2),

Recordando además que, en virtud de su Constitución, los Estados Miembros de la UNESCO “persuadidos de la necesidad de asegurar a todos el pleno e igual acceso a la educación; la posibilidad de investigar libremente la verdad objetiva y el libre intercambio de ideas y de conocimientos, resuelven desarrollar e intensificar las relaciones entre sus pueblos, a fin de que éstos se comprendan mejor entre sí y adquieran un conocimiento más preciso y verdadero de sus respectivas vidas" (Preámbulo, párrafo 6),

Recordando los objetivos y los principios de las Naciones Unidas tal como son definidos en su Carta,

Recordando la Declaración Universal de Derechos Humanos aprobada por la Asamblea General de las Naciones Unidas en 1948 y en particular el artículo 19 que estipula que "todo individuo tiene derecho a la libertad de opinión y de expresión; este derecho incluye el de no ser molestado a causa de sus opiniones, el de investigar y recibir informaciones y opiniones, y el de difundirlas, sin limitación de fronteras, por cualquier medio de expresión", así como el Pacto Internacional de Derechos Civiles y Políticos, aprobado por la Asamblea General de las Naciones Unidas en 1966, que proclama los mismos principios en su artículo 19 y que en su artículo 20 condena la incitación a la guerra, la apología del odio nacional, racial o religioso así como toda forma de discriminación, de hostilidad o de violencia,

Recordando el artículo 4 de la Convención internacional sobre la eliminación de todas las formas de discriminación racial, aprobada por la Asamblea General de las Naciones 
Unidas en 1965, y la Convención internacional sobre la represión y el castigo del crimen de apartheid, aprobada por la Asamblea General de las Naciones Unidas en 1973, que estipulan que los Estados adheridos a esas convenciones se comprometen a adoptar inmediatamente medidas positivas para eliminar toda incitación a esa discriminación o todo acto de discriminación y han decidido impedir que se estimule de cualquier modo que sea el crimen de apartheid y otras políticas segregacionistas similares,

Recordando la Declaración sobre el fomento entre la juventud de los ideales de paz, respeto mutuo y comprensión entre los pueblos, aprobada por la Asamblea General de las Naciones Unidas en 1965, Recordando las declaraciones y las resoluciones aprobadas por los diversos organismos de las Naciones Unidas relativas al establecimiento de un nuevo orden económico internacional, y el papel que la UNESCO está llamada a desempeñar en esta esfera,

Recordando la Declaración de los Principios de la Cooperación Cultural Internacional, aprobada por la Conferencia General de la UNESCO en 1966,

Recordando la resolución 59(I) de la Asamblea General de las Naciones Unidas, adoptada en 1946, que declara: "La libertad de información es un derecho humano fundamental y piedra de toque de todas las libertades a las cuales están consagradas las Naciones Unidas; . . . La libertad de información requiere, como elemento indispensable, la voluntad y la capacidad de usar y no abusar de sus privilegios. Requiere además, como disciplina básica, la obligación moral de investigar los hechos sin prejuicio y difundir las informaciones sin intención maliciosa;

Recordando la resolución 11O(II) aprobada en 1947 por la Asamblea General de las acciones Unidas, que condena toda propaganda destinada a provocar o a estimular amenazas contra la paz, la ruptura de la paz o todo acto de agresión,

Recordando la resolución 127(II) de la misma Asamblea General, que invita a los estados Miembros a luchar dentro de los límites constitucionales contra la difusión de noticias falsas o deformadas que puedan perjudicar las buenas relaciones entre Estados, así como las demás resoluciones de la citada Asamblea relativas a los medios de comunicación de masas y su contribución al desarrollo de la confianza y de las relaciones de amistad entre los Estados,

Recordando la resolución 9.12 aprobada por la Conferencia General de la UNESCO en 1968, que reafirma el objetivo de la Organización de contribuir a la eliminación del colonialismo y del racismo, así como la resolución 12.1 aprobada por la Conferencia General 
en 1976, que declara que el colonialismo, el neocolonialismo y el racismo en todas sus formas y manifestaciones son incompatibles con los objetivos fundamentales de la UNESCO,

Recordando la resolución 4.301, aprobada en 1970 por la Conferencia General de la UNESCO, relativa a la contribución de los grandes medios de comunicación de masas al fortalecimiento de la comprensión y la cooperación internacionales en interés de la paz y del bienestar de la humanidad, y a la lucha contra la propaganda en favor de la guerra, el racismo, el apartheid y el odio entre los pueblos, y consciente del papel fundamental que los medios de comunicación de masas pueden desempeñar en esas esferas,

Recordando la Declaración sobre la Raza y los Prejuicios Raciales aprobada por la Conferencia General en su 20.a reunión,

Consciente de la complejidad de los problemas que plantea a la sociedad moderna la información y de la diversidad de soluciones que se les ha aportado, y que ha puesto de manifiesto principalmente la reflexión llevada a cabo en el seno de la UNESCO, y en particular de la legítima preocupación de unos y otros por que se tomen en cuenta sus aspiraciones, sus opiniones y su personalidad cultural,

Consciente de las aspiraciones de los países en desarrollo en lo que respecta el establecimiento de un nuevo orden mundial de la información y la comunicación,

Proclama en este 28 día del mes de noviembre de 1978 la presente Declaración sobre los principios fundamentales relativos a la contribución de los medios de comunicación de masas al fortalecimiento de la paz y la comprensión internacional, a la promoción de los derechos del hombre y a la lucha contra el racismo, el apartheid y la incitación a la guerra.

Artículo primero

El fortalecimiento de la paz y de la comprensión internacional, la promoción de los derechos humanos, la lucha contra el racismo, el apartheid y la incitación a la guerra exigen una circulación libre y una difusión más amplia y equilibrada de la información. Para este fin, los órganos de información deben aportar una contribución primordial, contribución que será más eficaz si la información refleja los diferentes aspectos del asunto examinado.

\section{Articulo II}

1. El ejercicio de la libertad de opinión, de la libertad de expresión y de la libertad de información, reconocido como parte integrante de los derechos humanos y de las libertades fundamentales, constituye un factor esencial del fortalecimiento de la paz y de la comprensión internacional. 
2. El acceso del público a la información debe garantizarse mediante la diversidad de las fuentes y de los medios de información de que disponga, permitiendo así a cada persona verificar la exactitud de los hechos y fundar objetivamente su opinión sobre los acontecimientos. Para ese fin, los periodistas deben tener la libertad de informar y las mayores facilidades posibles de acceso a la información. Igualmente, los medios de comunicación deben responder a las preocupaciones de los pueblos y de los individuos, favoreciendo así la participación del público en la elaboración de la información.

3. Con miras al fortalecimiento de la paz y de la comprensión internacional, de la promoción de los derechos humanos y de la lucha contra el racismo, el apartheid y la incitación a la guerra, los órganos de información, en todo el mundo, dada la función que les corresponde, contribuyen a promover los derechos humanos, en particular haciendo oir la voz de los pueblos oprimidos que luchan contra el colonialismo, el neocolonialismo, la ocupación extranjera y todas las formas de discriminación racial y de opresión y que no pueden expresarse en su propio territorio.

4. Para que los medios de comunicación puedan fomentar en sus actividades los principios de la presente Declaración, es indispensable que los periodistas y otros agentes de los órganos de comunicación, en su propio país o en el extranjero, disfruten de un estatuto que les garantice las mejores condiciones para ejercer su profesión.

Articulo III

1 Los medios de comunicación deben aportar una contribución importante al fortalecimiento de la paz y de la comprensión internacional y a la lucha contra el racismo, el apartheid y la propaganda belicista.

2. En la lucha contra la guerra de agresión, el racismo y el apartheid, así como contra las otras violaciones de los derechos humanos que, entre otras cosas, son resultado de los prejuicios y de la ignorancia, los medios de comunicación, por medio de la difusión de la información relativa a los ideales, aspiraciones, culturas y exigencias de los pueblos, contribuyen a eliminar la ignorancia y la incomprensión entre los pueblos, a sensibilizar a los ciudadanos de un país a las exigencias y las aspiraciones de los otros, a conseguir el respeto de los derechos y la dignidad de todas las naciones, de todos los pueblos y de todos los individuos, sin distinción de raza, de sexo, de lengua, de religión o de nacionalidad, y a señalar a la atención los grandes males que afligen a la humanidad, tales como la miseria, la desnutrición y las enfermedades. Al hacerlo así favorecen la elaboración por los Estados de 
las políticas más aptas para reducir las tensiones internacionales y para solucionar de manera pacífica y equitativa las diferencias internacionales.

\section{Artículo IV}

Los medios de comunicación de masas tienen una participación esencial en la educación de los jóvenes dentro de un espíritu de paz, de justicia, de libertad, de respeto mutuo y de comprensión, a fin de fomentar los derechos humanos, la igualdad de derechos entre todos los seres humanos y naciones y el progreso económico y social. Igualmente desempeñan un papel importante para dar a conocer las opiniones y las aspiraciones de la nueva generación.

\section{Artículo V}

Para que se respete la libertad de opinión, de expresión y de información, y para que la información refleje todos los puntos de vista, es importante que se publiquen los puntos de vista presentados por aquellos que consideren que la información publicada o difundida sobre ellos ha perjudicado gravemente la acción que realizan con miras a fortalecer la paz y la comprensión internacional, la promoción de los derechos humanos, o a luchar contra el racismo, el apartheid y la incitación a la guerra.

\section{Artículo VI}

La instauración de un nuevo equilibrio y de una mejor reciprocidad de la circulación de la información, condición favorable para el logro de una paz justa y durable y para la independencia económica y política de los países en desarrollo, exige que se corrijan las desigualdades en la circulación de la información con destino a los países en desarrollo, procedentes de ellos, o entre unos y otros de esos países. Para tal fin es esencial que los medios de comunicación de masas de esos países dispongan de las condiciones y los medios necesarios para fortalecerse, extenderse y cooperar entre sí y con los medios de comunicación de masas de los países desarrollados.

\section{Artículo VII}

Al difundir más ampliamente toda la información relativa a los objetivos y a los principios universalmente aceptados, que constituyen la base de las resoluciones aprobadas por los diferentes órganos de las Naciones Unidas, los medios de comunicación de masas contribuyen eficazmente a reforzar la paz y la comprensión internacional, a la promoción de los derechos humanos, y al establecimiento de un nuevo orden económico internacional más justo y equitativo.

\section{Artículo VIII}


Las organizaciones profesionales, así como las personas que participan en la formación profesional de los periodistas y demás agentes de los grandes medios de comunicación y que les ayudan a desempeñar sus tareas de manera responsable deberían acordar particular importancia a los principios de la presente Declaración en los códigos deontológicos que establezcan y por cuya aplicación velan.

\section{Artículo IX}

En el espíritu de la presente Declaración, incumbe a la comunidad internacional contribuir a establecer las condiciones necesarias para una circulación libre de la información y para su difusión más amplia y más equilibrada, así como las condiciones necesarias para la protección, en el ejercicio de sus funciones, de los periodistas y demás agentes de los medios de comunicación. La UNESCO está bien situada para aportar una valiosa contribución en esa esfera.

\section{Artículo X}

1. Con el debido respeto de las disposiciones institucionales que garantizan la libertad de información y de los instrumentos y acuerdos internacionales aplicables, es indispensable crear y mantener en todo el mundo las condiciones que permitan a los órganos y a las personas dedicadas profesionalmente a la difusión de la información alcanzar los objetivos de la presente Declaración.

2. Es importante que se estimule una circulación libre y una difusión más amplia y más equilibrada de la información.

3. Con tal fin, es necesario que los Estados faciliten la obtención, para los medios de comunicación de los países en desarrollo, de las condiciones y los medios necesarios para fortalecerse y extenderse, y que favorezcan la cooperación entre ellos y con los medios de comunicación de los países desarrollados.

4. Asimismo, basándose en la igualdad de derechos, en la ventaja mutua y en el respeto de la diversidad de las culturas, elementos del patrimonio común de la humanidad, es esencial que se alienten y desarrollen los intercambios de información tanto bilaterales como multilaterales entre todos los Estados, en particular entre los que tienen sistemas económicos y sociales diferentes.

\section{Artículo XI}

Para que la presente Declaración sea plenamente eficaz, es preciso que, con el debido respeto de las disposiciones legislativas y administrativas y de las demás obligaciones de los Estados Miembros, se garantice la existencia de condiciones favorables para la acción 
de los medios de comunicación, de conformidad con las disposiciones de la Declaración Universal de Derechos Humanos y los principios correspondientes enunciados en el Pacto Internacional de Derechos Civiles y Políticos aprobado por la Asamblea General de las Naciones Unidas en 1966. 